\title{
AN ASSESSMENT OF FREEZE BRAND AND PIT TAG RECOVERY DATA AT MCNARY DAM, 1987
}

\author{
By : \\ Clinton Scott McCutcheon \\ and \\ Albert E. Giorgi

\begin{abstract}
Coastal Zone and Estuarine Studies Division Northwest Fisheries Center National Marine Fisheries Service
\end{abstract} \\ National Oceanic and Atmospheric Administration

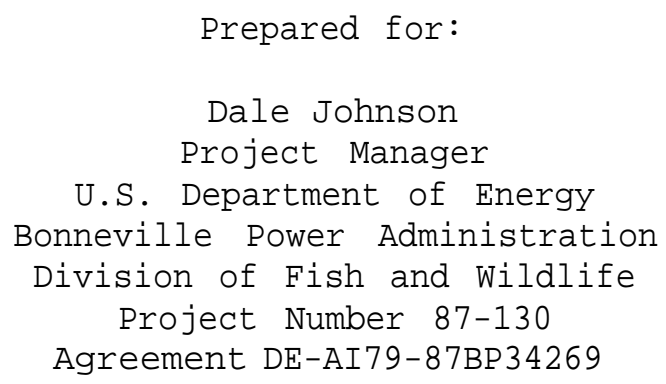

January 1989 


\begin{abstract}
This study evaluated mark recovery data from PIT-tagged and freeze-branded fish recovered at McNary Dam in 1987. Hatchery and river-run populations of yearling

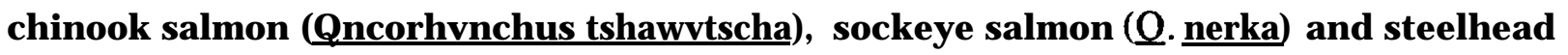
(ㅁ. $\underline{\text { mykiss) }}$ were used in this investigation. Paired groups of PIT-tagged and freezebranded juvenile salmonids were released upstream from McNary Dam and subsequently recaptured at that site.

PIT tags were recovered in significantly higher proportions than freeze brands regardless of species or stock. Furthermore, for chinook and sockeye salmon, PIT tag recovery data exhibited less variability. Reasons for the discrepant intermark recovery rates are discussed.
\end{abstract}




\section{CONTENTS}

INTRODUCTION $\ldots \ldots \ldots \ldots \ldots \ldots \ldots \ldots \ldots \ldots \ldots \ldots \ldots \ldots$

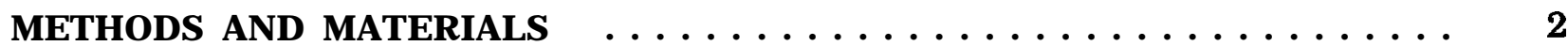

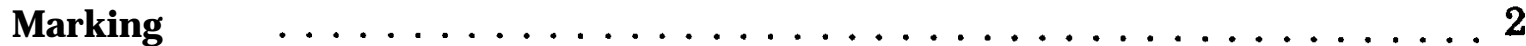

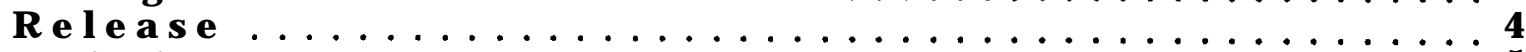

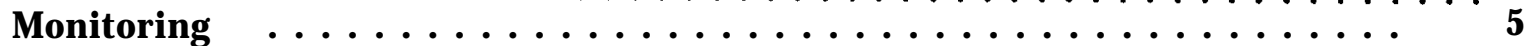

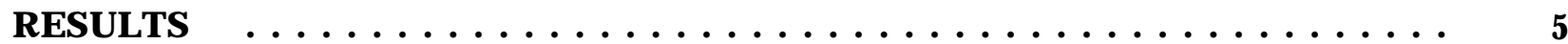

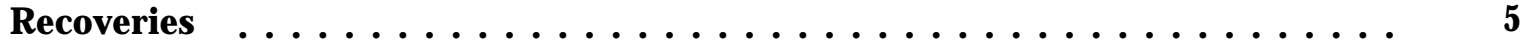

Yearling Chinook Salmon $\ldots \ldots \ldots \ldots \ldots \ldots \ldots \ldots \ldots \ldots, 5$

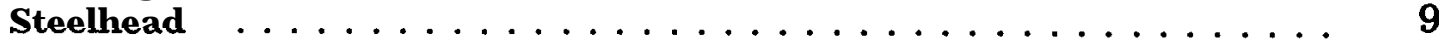

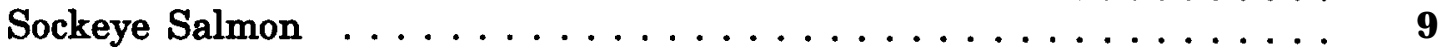

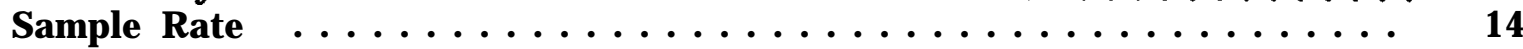

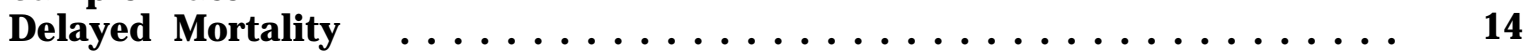

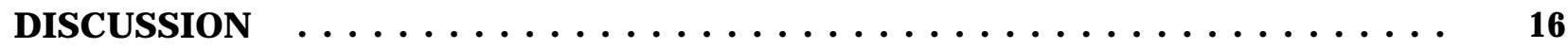

SUMMARY AND CONCLUSIONS $\ldots \ldots \ldots \ldots \ldots \ldots \ldots \ldots \ldots \ldots \ldots \ldots$

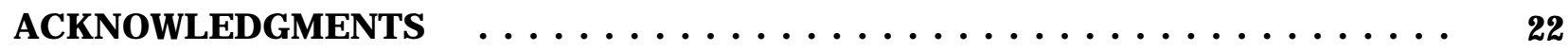

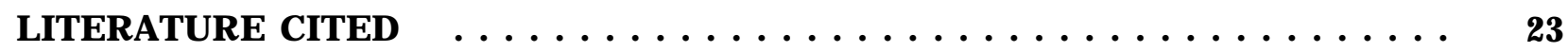

APPENDIX A

Summaries of PIT Tagging and Freeze Branding $\ldots \ldots \ldots \ldots \ldots \ldots \ldots . \ldots . \ldots 24$

APPENDIX B

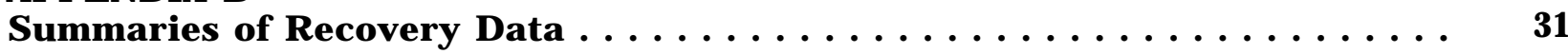

APPENDIX C

Figures of Recaptures by Date $\ldots \ldots \ldots \ldots \ldots \ldots \ldots \ldots \ldots \ldots \ldots$

APPENDIX D

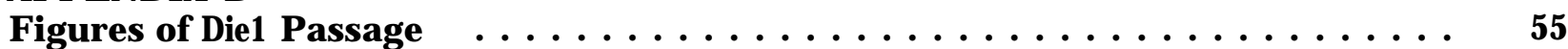

APPENDIX E

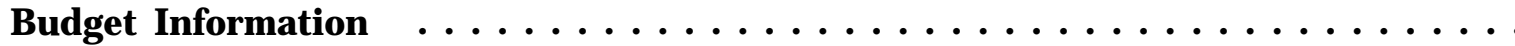




\section{INTRODUCTION}

Recent studies conducted at Columbia River dams revealed that PIT-tagged

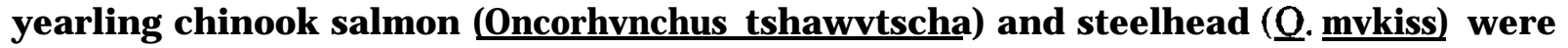
recovered at significantly higher rates than those that were freeze-branded (Prentice et al. 1987). In one study, river-run yearling chinook salmon were PIT-tagged or branded, released at the same time and location into the forebay, and subsequently recaptured at McNary Dam. Overall recovery rates for brands (expanded for sample size) and PIT tags (actual) were 38.9 and $63.6 \%$, respectively. Similar results were observed at Lower Granite Dam when evaluating data for spring chinook salmon released from Dworshak National Fish Hatchery (DNFH) in 1986 (Prentice et al. 1987). At Lower Granite Dam, brands and PIT tags were recovered at a rate of 11.5 and $18.9 \%$, respectively. This discrepancy in recovery rates persisted downstream at McNary Dam, with $8.9 \%$ of the brands and $10.8 \%$ of the PIT tags recovered at that site. Similar results were obtained for steelhead released from DNFH; at Lower Granite Dam, 20.2\% of the brands and $38.1 \%$ of the PIT tags were recovered (Prentice et al. 1987). The large discrepancies in mark recovery rates suggest a potential bias may be associated with the recovery process.

Additional research was conducted by the National Marine Fisheries Service (NMFS) in 1987 to explore the recovery rates of branded and PIT-tagged fish. Specifically the objectives were to 1) determine if freeze-branded and PIT-tagged yearling chinook salmon, sockeye salmon (ㅇ. nerka), and steelhead are consistently recovered at different rates and 2) if discrepancies exist, attempt to identify the sources of error in the sampling process. 


\section{METHODS AND MATERIALS}

\section{Marking}

Fish for the study were marked at a number of hatcheries: spring chinook salmon--Winthrop National Fish Hatchery (WNFH), steelhead and yearling fall chinook salmon--Lyons Ferry Hatchery (LFH), and steelhead--Wells Hatchery. Additionally, migrating yearling chinook and sockeye salmon were collected for marking at Priest Rapids Dam on the Columbia River (Fig. 1). Details regarding dates, sizes, and numbers marked for each test are summarized in Appendix A.

The spring chinook salmon at Priest Rapids Dam were the only groups branded exclusively for our evaluation; the other groups were branded primarily for other studies. Fish branded at the hatcheries were used for the Smolt Monitoring Program (SMP) evaluation and our study. Sockeye salmon branded at Priest Rapids Dam were marked by the NMFS for use in transportation evaluation (Dell et al. 1985).

Branding and PIT tagging were conducted concurrently for each release group. The only exception being that subsets of the three groups of spring chinook salmon branded in the fall at WNFH were remarked with the PIT tag in the spring. Freeze branding was done using methods described by Mighell (1969). The PIT-tagging method of auto-injection (Prentice et al. 1987) was used at all marking locations except WNFH, where the hand injection system was used (Prentice et al. 1986, Appendix A). The sockeye salmon at Priest Rapids were also adipose clipped and coded wire tagged (Jefferts et al. 1963) using multiple marking procedures described by Park et al. (1974).

Fish were selected from the general population for both mark methods, and unusable fish were culled from both mark groups using the same criteria. Fish were rejected prior to marking (brand or tag) if they were injured, descaled, previously marked, obviously diseased, or precocious males. Approximately $4 \%$ of the branded fish selected for tagging at WNFH were rejected because they exhibited obvious external signs of bacterial kidney disease (BKD). 
C $\quad A \quad N \quad A \quad D \quad A$

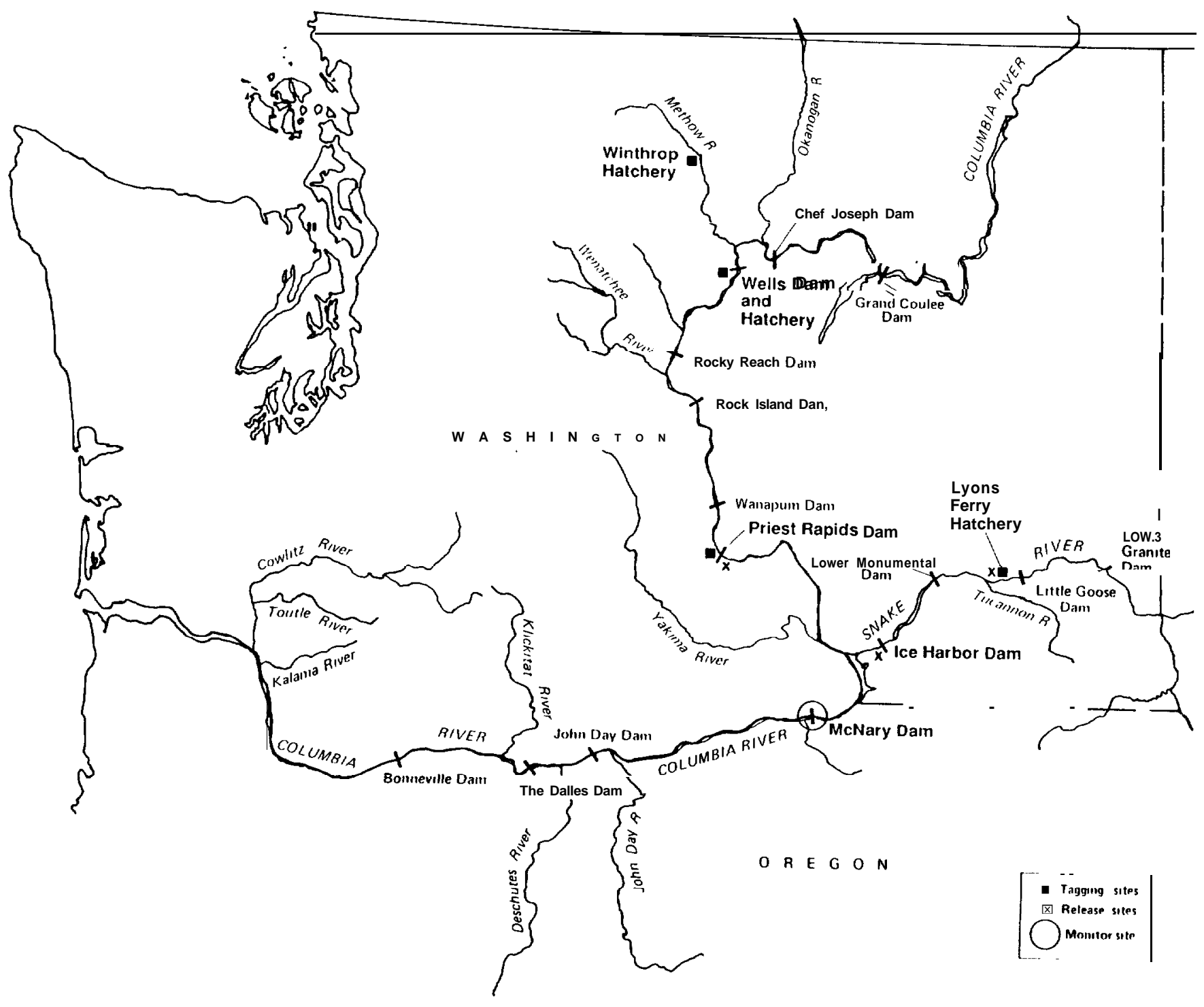

Figure 1.--Locations of the marking, release, and monitor sites; 1987. 
Some groups from Priest Rapids Dam were marked over several days due to the small numbers of fish available from the gatewell sampling on any single day. For the chinook salmon marked in this manner, brands were changed daily to identify individual release days.

\section{Release}

At LFH and WNFH marked fish were held at the hatcheries for several weeks prior to release, and mortalities were documented. Additionally, freeze-branded fish were evaluated for brand legibility by FPC staff (FPC 1988). To estimate the number of branded fish released, the number of observed mortalities and estimated number of illegible marks were deducted from the total number tagged. To document the number of PIT-tagged fish released, mixed groups of branded and PIT-tagged fish were pumped into tanker trucks for distribution. Tagged fish were interrogated as they passed through a pump fitted with a PIT tag detector (Prentice et al. 1988). Only the tag codes confirmed at the time of release were used for intermark comparisons in this evaluation.

At Wells Hatchery steelhead were released only 3 days after marking. At the end of the 3-day period, mortalities were enumerated and brands were examined for legibility. Release numbers were adjusted accordingly.

At Priest Rapids Dam, river-run fish were marked and released on the same day. Additionally, samples ( $n=50)$ of spring chinook and sockeye salmon were held for 5 days to document tag loss, delayed mortality, and brand legibility.

Most marked groups were released in the tailrace below Priest Rapids Dam. Only fish from LFH were released in different locations--fall chinook salmon were released directly from the hatchery whereas steelhead were released in the tailrace below Ice Harbor Dam. Marked fish (branded and tagged mixed together) were transported to the release sites via tanker trucks by FPC contractors (FPC 1988). 


\section{Monitoring}

Marked fish were recovered at the McNary Dam collection facility. Brand recovery data were processed by NMFS personnel as part of the Smolt Monitoring Program. Branded fish were enumerated in a subsample systematically extracted from the bypass population. The estimated number of a particular brand present in the bypass population (often referred to as the "expanded" estimate) was calculated as the ratio of the number of brands observed in the sample to the proportion of time the sample was extracted (Giorgi and Sims 1987).

PIT-tagged fish were passively monitored while exiting the separator at McNary Dam (Prentice et al. 1987). The system interrogated $100 \%$ of the bypass population. An additional monitor placed in the sub-sample room identified tagged fish diverted into the subsample (Fig. 2).

PIT tag recovery data specify the date and time (to minute) tags were detected. Recovery data for brands were pooled over a 24-h period (noon to noon). For comparative purposes, daily PIT tag recovery data were adjusted to the same time frame.

\section{RESULTS}

A total of 8,120 PIT-tagged and 168,906 freeze-branded juvenile salmonids were marked in 1987 to evaluate the McNary Dam collection facility (Appendix A).

\section{Recoveries}

\section{Yearling Chinook Salmon}

A total of 564 PIT-tagged and an estimated 9,658 branded spring chinook salmon were detected from groups marked at Winthrop National Fish Hatchery and released below Priest Rapids Dam (Table 1). The mean recovery rate for three groups of PITtagged spring chinook was $44.0 \%(\mathrm{SD}=\mathbf{2 . 8 \%}$ ) (Table 2$)$. Recovery rates for individual 
Fish funnel

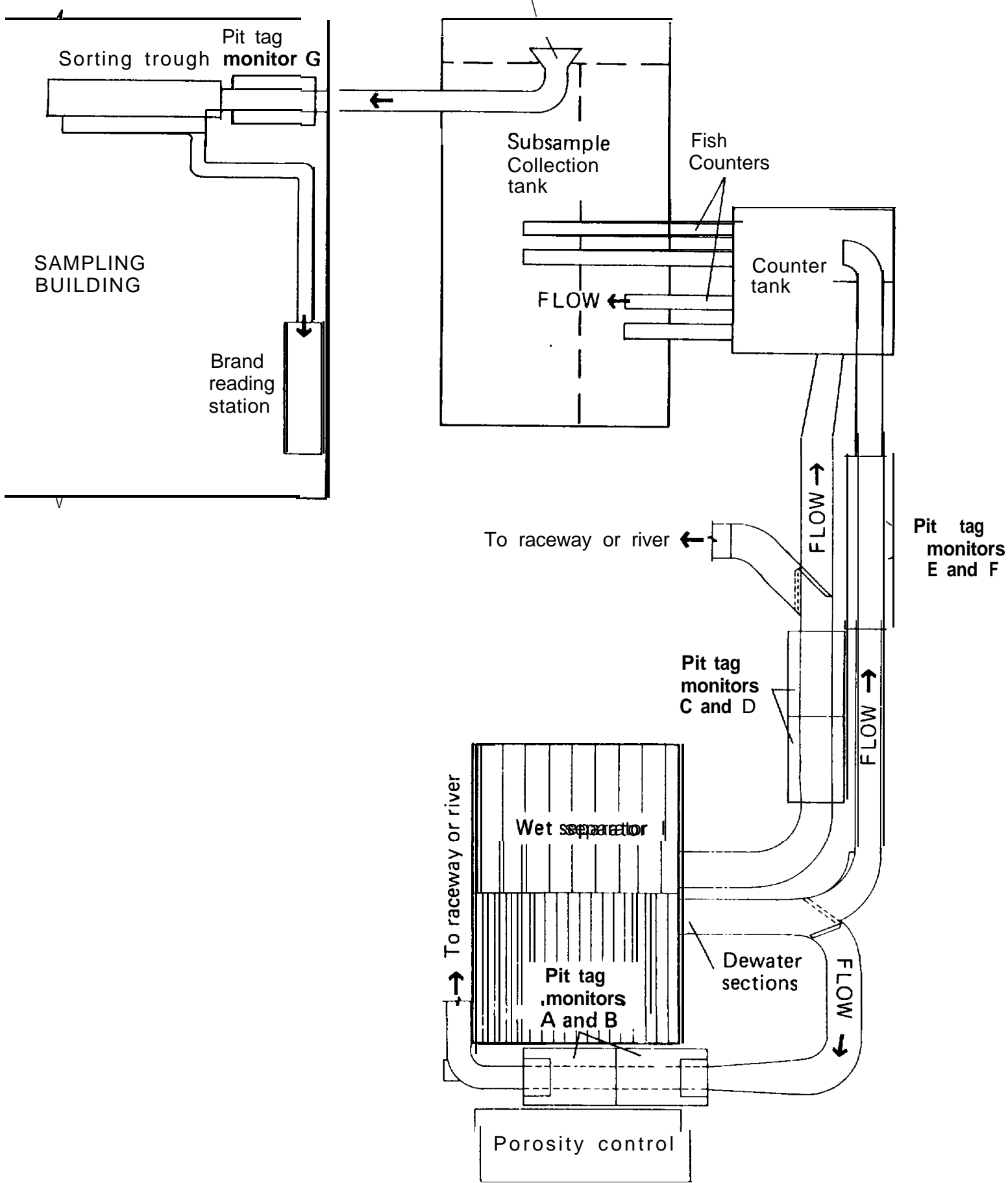

Figure 2.--Overview of the McNary Dam fish sampling system showing the location of PIT-tag monitors in 1987. 


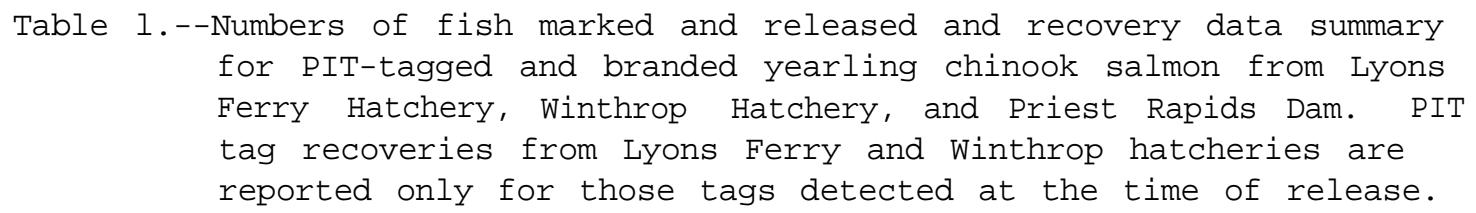

\begin{tabular}{|c|c|c|c|c|}
\hline \multirow{2}{*}{$\begin{array}{l}\text { Fi sh source } \\
\text { and rel ease }\end{array}$} & \multirow[t]{2}{*}{ Number marked } & \multirow[t]{2}{*}{ Nunber rel eased } & \multirow{2}{*}{$\frac{\text { Nunber recovered }}{\text { Brand }}$} & Percent recovered \\
\hline & & & & Bra \\
\hline
\end{tabular}

$\begin{array}{lllllllll}\text { date } & \text { Pit } & \text { taq } & \text { Brand } & \text { PIT tag } & \text { Brand }^{\mathrm{b}} & \text { PIT taq } & \text { Sampl ed Expanded } & \text { PIT tag Exp. }\end{array}$

LYONS FERRY

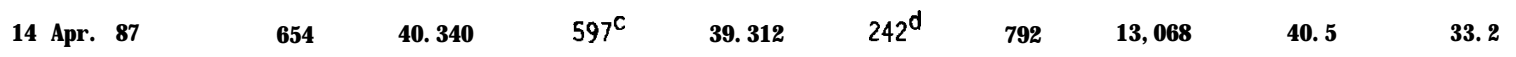

\section{W NTHROP}

$\begin{array}{cccccccccc}20 \text { Apr. } 87 & 660 & 12.230 & 303^{c} & 10.658 & 132^{d} & 242 & 3,789 & 43.6 & 35.5 \\ 24 \text { Apr. } 87 & 654 & 12.200 & 430 c & 11.029 & 178^{d} & 125 & 2,081 & 41.4 & 18.9 \\ 28 \text { Apr. } 87 & \underline{678} & \underline{12.200} & \underline{542^{c}} & \underline{11.300} & \underline{254}^{d} & \underline{215} & \underline{3.788} & 46.9 & 33.5 \\ \text { Total } & 1.992 & 36,630 & 1,275 & 32,987 & 564 & 572 & 9.658 & \end{array}$

\begin{tabular}{|c|c|c|c|c|c|c|c|c|c|}
\hline 05 Hay 87 & 600 & 5,993 & 599 & 5, 993 & 371 & 53 & 976 & 61.9 & 16.3 \\
\hline 09 May 87 & 600 & 6,000 & 600 & 6.000 & 351 & 211 & 2,195 & 58.5 & 36.6 \\
\hline 13-16 Мyy 87 & 600 & 6.034 & 598 & 6,034 & 358 & 430 & 2,809 & 59.9 & 46.6 \\
\hline Total & 1.800 & 18.027 & 1,797 & 18,027 & 1.080 & 694 & 5,980 & & \\
\hline
\end{tabular}

\footnotetext{
a Losses i ncl ude raceway nortal ities, tag rejecti ons, and snol t condi ti on sampl i ng.

b Losses i ncl ude raceway nortal iti es, adj ustnents for brand l egi bi lity, and snol t condi ti on sanpli ng.

c PI T tags detected at rel ease usi ng rel ease noni tors.

d PI T tags recapt ured at MtNary Damfromtags detected at rel ease.
} 
Table 2.--Mean recovery rate and standard deviation for groups of PIT-tagged and branded fish at McNary Dam, 1987.

\begin{tabular}{|c|c|c|c|c|c|}
\hline & & & Number of & Recovery & rate $\left(\frac{\circ}{0}\right)$ \\
\hline Species or race & Source of fish & Mark & groups & Mean & $\mathrm{SD}$ \\
\hline Spring chinook & Winthrop & PIT & 3 & 44.0 & 2.8 \\
\hline & & Brand & 3 & 29.3 & 9.1 \\
\hline Yearling chinook & Rapids migrants & PIT & 3 & 60.0 & 1.7 \\
\hline & & Brand & 3 & 33.1 & 15.4 \\
\hline \multirow[t]{2}{*}{ Yearling Fall chinook } & Lyons Ferry Hatchery & PIT & 1 & 40.5 & \\
\hline & & Brand & 1 & 33.4 & \\
\hline \multirow[t]{2}{*}{ Sockeye } & Rapids migrants & PIT & 3 & 34.2 & 4.0 \\
\hline & & Brand & 3 & 22.8 & 10.0 \\
\hline \multirow[t]{2}{*}{ Steelhead } & Wells Hatchery & PIT & 3 & 34.3 & 3.2 \\
\hline & & Brand & 3 & 26.9 & 1.9 \\
\hline \multirow[t]{2}{*}{ Steelhead } & Lyons Ferry Hatchery & PIT & 3 & 30.4 & 2.5 \\
\hline & & Brand & 3 & 25.5 & 2.4 \\
\hline
\end{tabular}


groups ranged from 41.4 to $46.9 \%$ (Table 1). The branded counterparts were recovered at a significantly $(\mathrm{P} \leq 0.001)$ lower rate of $29.3 \%(\mathrm{SD}=9.1 \%)$ (Table 3; Fig. 3).

Of 1,797 PIT-tagged and 18,027 branded river-run yearling chinook salmon marked and released at Priest Rapids Dam, 1,080 and 5,980 were recovered, respectively (Table 1). The three PIT-tagged groups were recovered at an average rate of $60.0 \%(\mathrm{SD}=1.7 \%)($ Table 2$)$. The corresponding branded groups were recovered at a significantly $(\mathrm{P}<0.001)$ lower rate of $33.1 \%(\mathrm{SD}=15.4 \%)($ Tables 2 and 3; Fig. 3$)$.

A total of 242 tagged and an estimated 13,068 branded fall chinook salmon were recovered from a single group marked at Lyons Ferry Hatchery (Table 1). Tags and brands were recovered at significantly $(\mathrm{P} \leq 0.002)$ different rates of 40.5 and $33.2 \%$, respectively (Tables 1 and 3).

Steelhead

A total of 644 tagged and an estimated 9,224 branded steelhead were recovered from three paired groups marked at Wells Hatchery (Table 4). The mean recovery rate for three groups of PIT-tagged fish was 34.3\% (SD = 3.2\%). The branded counterparts were recovered at a significantly $\left(\mathrm{P}_{\leq} 0.001\right)$ lower rate of $26.9 \%(\mathrm{SD}=1.9 \%)$ (Tables 2 and 3; Fig. 3).

A total 451 tagged and an estimated 8,729 branded fish were recovered from fish marked at Lyons Ferry Hatchery (Table 4). The mean recovery rate for three groups of tagged fish was $30.4 \%(\mathrm{SD}=\mathbf{2 . 5 \%}$ ). The branded counterparts were recovered at a significantly $(\mathrm{P} \leq 0.001)$ lower rate of 25.5\% $(\mathrm{SD}=2.4 \%)($ Tables 2 and 3; Fig. 3).

\section{Sockeye Salmon}

A total of 616 tagged and an estimated 3,643 branded sockeye salmon were recovered from groups marked at Priest Rapids Dam (Table 5). The mean recovery rate for three groups of PIT-tagged fish was 34.2\% (s.d. = 4.0\%). The branded 
Table 3.--Results from Chi-square test comparing recapture rates of PIT-tagged vs branded fish ( 1 degree of freedom). Recaptures were pooled over all replicates for these comparisons.

\begin{tabular}{|c|c|c|c|}
\hline Species or race & Source of fish & $x^{2}$ & Probability \\
\hline Spring chinook & Winthrop & 131.2 & <0. 0001 \\
\hline Yearling chinook & Priest Rapids migrants & 516.7 & $\leq 0.0001$ \\
\hline Yearling fall chinook & Lyons Ferry Hatchery & 14.1 & $\leq 0.0002$ \\
\hline Sockeye & Priest Rapids migrants & $110 \cdot 6$ & $\leq 0.0001$ \\
\hline Steelhead & Hatchery & 40.9 & $\leq 0 \cdot 0001$ \\
\hline Steelhead & Lyons Ferry Hatchery & $148 \cdot 5$ & $\leq 0.0001$ \\
\hline
\end{tabular}




\section{Mark Recovery Rates (Means) at McNary Dam, 1987}

W PIT Tagged Branded

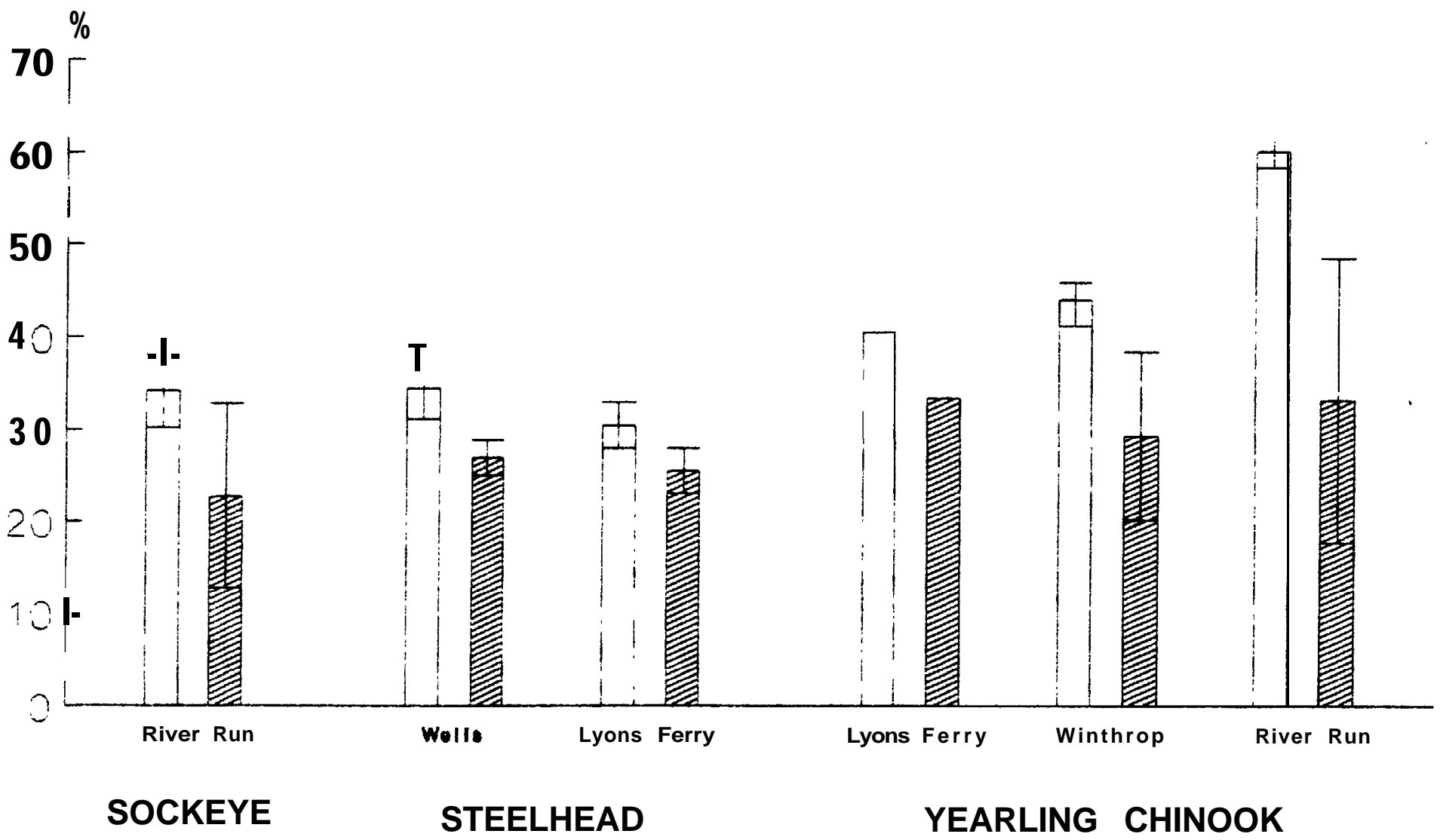

Figure 3. --Mean mark recovery $\left(\frac{\circ}{\circ}\right)$ and standard deviations (vertical lines) for paired releases of PIT-tagged and branded fish recovered at McNary Dam in 1987 (K=3). 
Tabl e 4. - - Nunber of fi sh marked and rel eased and recovery data summary for PI T-tagged and branded steel head. PI T tag recoveries from Lyons Ferry Hatchery are reported onl y for those tags detected at rel ease.

\begin{tabular}{|c|c|c|c|c|c|c|c|c|c|}
\hline \multirow{3}{*}{$\begin{array}{l}\text { Source and } \\
\text { rel ease } \\
\text { Date } \\
\end{array}$} & Nunber & \multirow{3}{*}{$\begin{array}{l}\text { marked } \\
\text { Brand }\end{array}$} & \multicolumn{2}{|c|}{ Number rel eased } & \multicolumn{3}{|c|}{ Number recovered } & \multicolumn{2}{|c|}{ Percent recovered } \\
\hline & \multirow[b]{2}{*}{ PIT ta } & & \multirow[b]{2}{*}{$\mathbf{P I} \mathbf{T} \operatorname{tag}^{\mathrm{a}}$} & \multirow[b]{2}{*}{ Brand ${ }^{b}$} & \multirow[b]{2}{*}{ PI T } & \multicolumn{2}{|c|}{ Brand } & \multirow{2}{*}{\multicolumn{2}{|c|}{ PI T tag $\frac{\text { Brand }}{\text { (Expanded) }}$}} \\
\hline & & & & & & Sampled & Expanded & & \\
\hline \multicolumn{10}{|l|}{ Well Is } \\
\hline 23 Apr. 87 & 637 & II. 500 & 631 & II. 279 & 195 & 182 & 2,849 & 30.9 & 25.2 \\
\hline 27 Apr. 87 & 633 & 11.430 & 632 & 10.898 & 220 & 204 & 3.303 & 34.8 & 28.9 \\
\hline n। May 87 & 630 & 11.546 & 616 & 11.375 & $\underline{229}$ & 174 & 3,072 & 37.2 & 26. 6 \\
\hline Total & 1.900 & 34.476 & 1,878 & 33. 552 & 644 & 560 & 9.224 & & \\
\hline Lyons Ferry & & & & & & & & & \\
\hline 23 Apr. 87 & 653 & 11,400 & $421^{c}$ & 11,279 & $116^{d}$ & 207 & 3.062 & 27.5 & 27.1 \\
\hline 27 Apr. 87 & 659 & 11,600 & $533^{c}$ & II . 478 & $171^{d}$ & 173 & 2,612 & 32.1 & 22.8 \\
\hline 01 May 87 & 653 & 11,590 & $524^{c}$ & 11.473 & $\underline{165}^{d}$ & 207 & 3,055 & 31.5 & 26.6 \\
\hline Total & 1. 965 & 34. 590 & 1,478 & 34.230 & 451 & 587 & 8,729 & & \\
\hline
\end{tabular}

a Losses i ncl ude raceway nortal i ti es- tag rej ecti ons, and snol t condi ti on sampl i ng.

b Losses i ncl ude racenay nortal i ti es, adj ust nents for brand l egi bi l i ty, and snol $t$ condi ti on sampl i ng.

c PI T tags detected at rel ease usi ng rel ease noni tors.

d PI T tags recapt ured at MtNary Damfromtags detected at rel ease. 


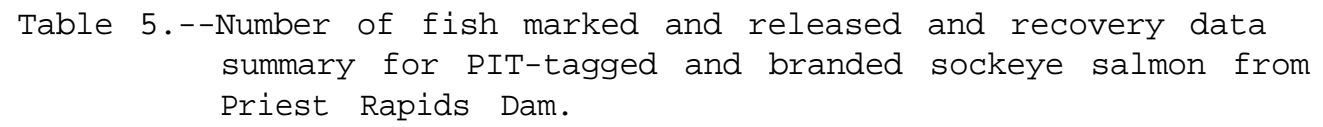

\begin{tabular}{|c|c|c|c|c|c|c|c|c|c|}
\hline \multirow{3}{*}{$\begin{array}{l}\text { Rel ease } \\
\text { date }\end{array}$} & Number & \multirow[t]{2}{*}{ marked } & \multirow[t]{2}{*}{ Nunber } & rel eased & \multicolumn{3}{|c|}{ Nunber recovered } & \multicolumn{2}{|c|}{ Percent Recovered } \\
\hline & \multirow[b]{2}{*}{ PI T ta } & & & \multirow[b]{2}{*}{ Brand } & \multirow[b]{2}{*}{ PI T } & \multicolumn{2}{|c|}{ Brand } & \multirow[b]{2}{*}{ PIT tag } & \multirow{2}{*}{$\frac{\text { Brand }}{\text { Expanded }}$} \\
\hline & & Brand & PIT tag & & & Sampl ed & Expanded & & \\
\hline 7-14 hay 87 & 600 & 5.424 & 600 & 5.424 & 206 & 180 & 1.600 & 34.3 & 29.5 \\
\hline 18-23 May 87 & 600 & 5,349 & 600 & 5. 349 & 229 & 217 & I. 471 & 38.2 & 27.5 \\
\hline 24-25 May 87 & 600 & 5,050 & 600 & 5,050 & 181 & 77 & 572 & 30.2 & 11.3 \\
\hline Total & 1,800 & 15,823 & 1,800 & 15,823 & 616 & 474 & 3. 643 & & \\
\hline
\end{tabular}


counterparts were recovered at a significantly $\left(\mathrm{P}_{\leq} \mathbf{0 . 0 0 1}\right)$ lower rate of $22.8 \%$ (s.d. = 10.0\%) (Tables 2 and 3; Fig. 3).

\section{Sample Rate}

The percentage of tagged fish exiting the separator, which were detected in the sample, ranged from 2.5 to $15.9 \%$ throughout the recovery period for each marked group (Table 6). Recoveries prior to 2 May were not included since the auxiliary detector in the sample room was not functional until that date. The sample rates based on tag recoveries varied considerably among and within species and stocks (Table 6). Generally, these rates were inconsistent with the sample rates estimated from the prescribed timer setting (estimated by FPC staff) prevailing during the same recovery periods (Table 6). These data suggest the sample may not be extracted at the rate prescribed on the timer. However, the evidence is inconclusive because the effective sampling rate associated with intradaily adjustments of the timer may not be truly reflected in the weighting factor used by the FPC (1988), and very few PIT-tagged fish entered the sample, thus the resultant estimated sample rate was questionable. We will attempt to resolve this problem in 1988 by releasing an ample number of tagged fish directly into the system and requesting that timer settings be adjusted once a day at a standard time.

\section{Delayed Mortality}

At Priest Rapids Dam, 50 fish of each species (chinook and sockeye salmon) and mark type were held for a 5-day period following marking to assess the extent of delayed mortality and tag rejection. No mortalities or tag rejections were observed in any group. Furthermore, all brands were legible 4 days after branding. 
Table 6. Comparison of estimated sample rates over the recovery period for individual groups based on the ratio of PIT tags observed in the sample to those detected exiting the separator versus the prescribed timer setting over each marked recovery period. The prescribed daily rate was based on weighted rates calculated by the FPC and reflected in the estimated numbers of brands in the daily collection (Appendix B). Only fish recovered on and after 2 May are used in this analysis.

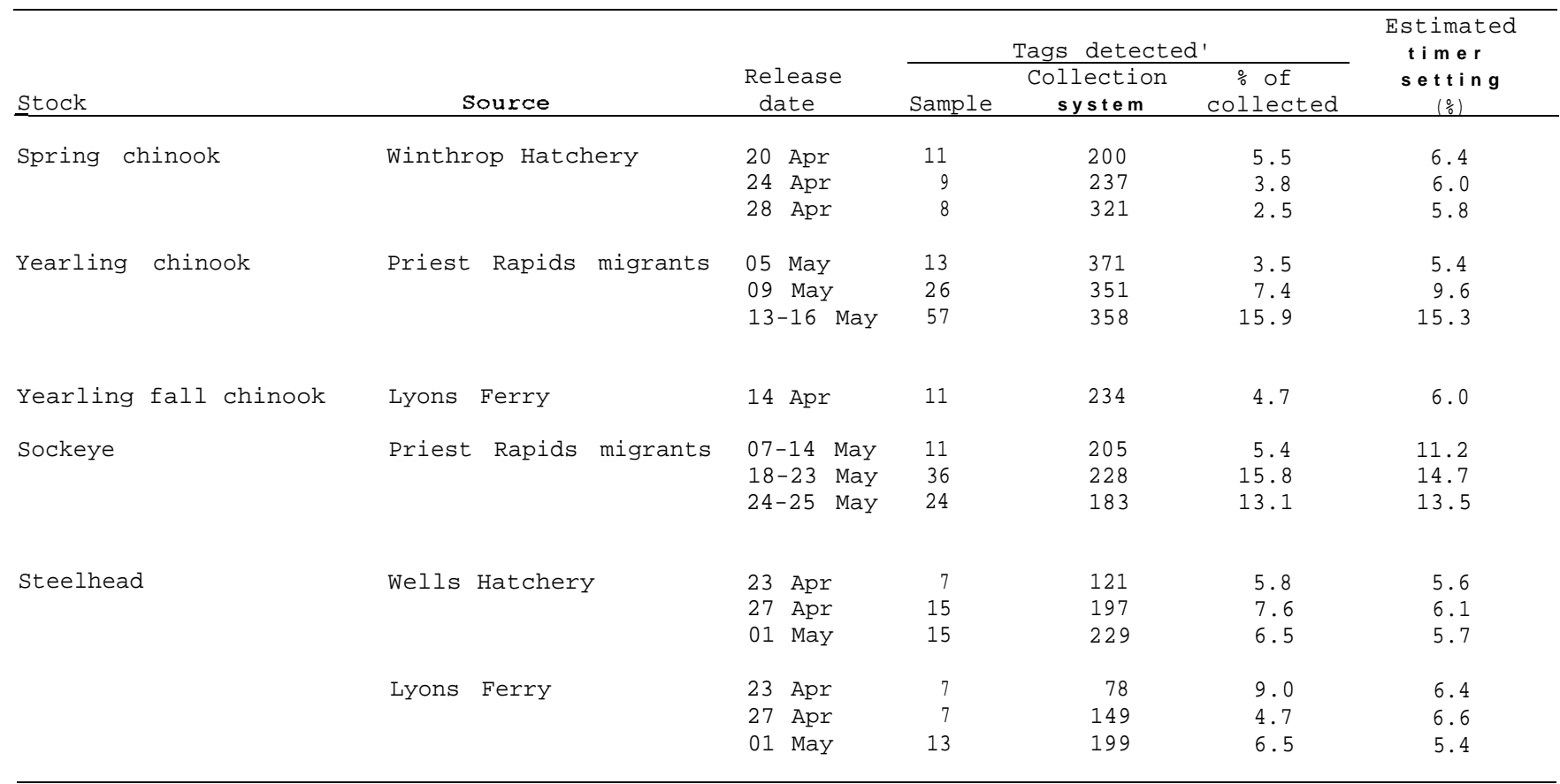

${ }^{1}$ All PIT tags detected at McNary Dam were used to construct this table, this includes tags from Winthrop and Lyons Ferry hatcheries which were not detected at the time of release but were subsequently detected at the dam. 


\section{DISCUSSION}

When Prentice et al. (1986) reported that PIT-tagged river-run yearling chinook salmon were recovered at a significantly higher rate than branded counterparts, a criticism of the finding was that the brands may not have had sufficient time to develop prior to arriving at McNary Dam. In our study, hatchery stocks were examined and brand release groups were adjusted for legibility and post marking mortality using FPC data. Also, river-run fish marked at Priest Rapids Dam arrived at the brand reading room at McNary Dam no sooner than 4 days after marking, thus permitting sufficient time for brands to be developed. It appears then, that the difference in mark recovery was not due to poorly developed brands. However, this assumes that the adjustment for brand legibility as evaluated at the hatchery reflects the actual legibility of the brand several weeks later under the environmental conditions prevailing at the sampling site.

Furthermore, the data demonstrate that regardless of species or stock, PIT-tagged fish were recovered at significantly higher rates than their branded counterparts (Tables 2 and 3). The consistently low recovery of brands suggests that either the brand processing crew was missing brands in the sample or the sample was being diverted from the collected population at a rate different than the prescribed timer setting. In 1987, we attempted to address these two explanations by placing a PIT-tag detector in the sample room to interrogate every PIT-tagged fish entering the facility. Unfortunately, fewer PIT-tagged fish entered the sample than we anticipated, and as a consequence, we cannot draw any conclusions from the data. However in 1988, research will evaluate the source of sampling error with a study designed to provide adequate mark recoveries in the sample.

A key assumption underlying our interpretation of these results is that the tagging and branding processes have the same affect on the fish, in terms of survival, 
behavior, or locomoting performance. Research by Prentice at al. (1987) supports this assumption. In that study, branded, CWT, PIT-tagged, and control groups of steelhead, as well as yearling and subyearling chinook salmon, were evaluated with respect to survival, swimming performance, and growth. No differences were observed among the groups.

Yearling chinook salmon from WNFH were handled in a different manner than the other lots of fish. These fish had been branded prior to the time they were tagged. Furthermore, approximately $4 \%$ were rejected for tagging because they exhibited gross BKD symptoms. This selective marking may in part be responsible for the higher recovery proportion of the tagged fish. However, the difference in mean recovery proportions are consistent with those observed in other groups of yearling chinook salmon (Table 1). Furthermore, the observed difference between tagged and branded fish far exceeds the amount which could be attributed to $4 \%$ culling.

PIT-tagged yearling chinook salmon from Winthrop Hatchery were consistently recovered at lower rates than their river-run counterparts from Priest Rapids Dam, averaging 44.0 and $60.0 \%$, respectively (Tables 1 and 2). The disparity in recovery may be associated with differences in the behavioral characteristics of the two groups of fish. Hatchery fish released directly into the McNary Pool may have exhibited higher postrelease mortality enroute to the dam. There is evidence to support this explanation. On the average, Winthrop fish (PIT- tagged) traversed the pool in 11.3 days whereas river-run chinook salmon from Priest Rapids Dam traveled the same distance in 5.3 days (Fig. 4). As a consequence, Winthrop fish could have incurred more predator related mortality, since they were in the pool for a more protracted period. Alternatively, fish released directly from the hatchery may not have been as smolted as the river-run population (Rondorf et al. 1985) and as a consequence may not have been collected at the same rate. Giorgi et al. (1988) presented data which indicate that yearling chinook salmon in the early stages of smolt development were not as 


\section{PIT TAGGED CHINOOK SALMON RELEASED AT PRIEST RAPIDS DAM}

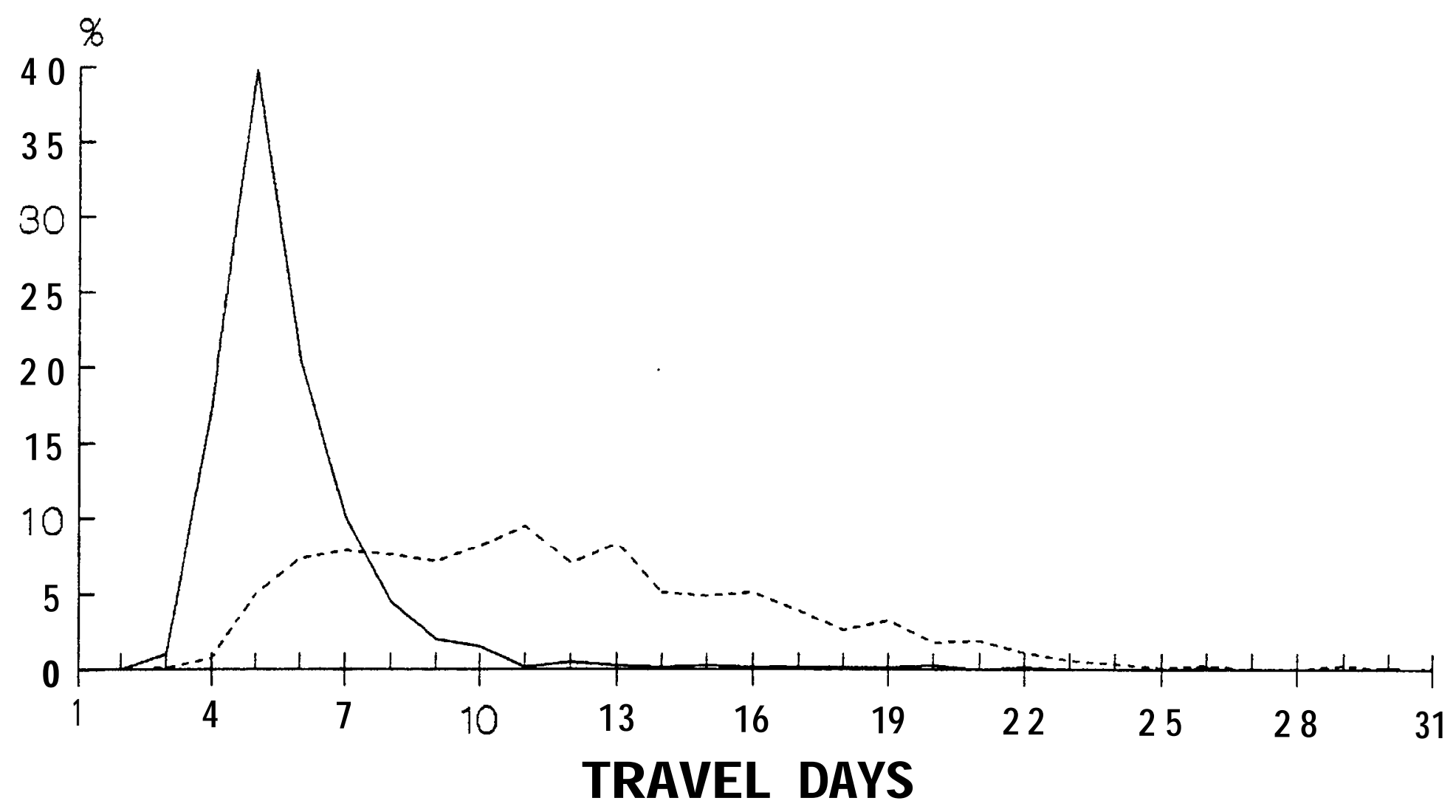

-.-- HATCHERY STOCK — MIGRANTS

Figure 4.--Percent recovery of two PIT-tagged groups of yearling chinook salmon released below Priest Rapids Dam and recovered at McNary Dam in 1987. The hatchery fish were from Winthrop National Fish Hatchery. The migrants were river-run fish captured at Priest Rapids Dam. 
susceptible to guidance by STSs as fish in later stages of smolt development. A third possible explanation is that the Winthrop groups may have passed the facility under high levels of spill and were subjected to a lower rate of collection; data, however, do not support this explanation. Peak passage of the Winthrop releases occurred during the first week of May (Appendix Fig. C2) whereas chinook salmon marked at Priest Rapids peaked about 1 week later (Appendix Fig. C3). Spill levels were actually lower during the passage of the Winthrop releases (Fig. 5) so collection should have been greater for these fish, just the reverse of what was observed.

The recovery data for sockeye salmon illustrated an important source of error associated with brands. Brand recovery for three groups ranged from 11.3 to $29.5 \%$ (Table 5) whereas the corresponding tagged groups ranged from 30.2 to $38.2 \%$. Inspection of the frequency distribution (Appendix Fig. C6) for Group 1, shows an apparent pulse of branded (Brand LA W2) fish were recorded at the facility on 30 May; however, PIT tag recoveries did not indicate a similar increase in recovery numbers. It appears that the observed pulse of branded fish was actually comprised of misread brands from the third release group, Brand LA W4 (Fig. 6). This would explain why no fish were recorded from the third release group on 30 May and the inordinately low recovery rate $(\mathbf{1 1 . 3 \% )}$ for that group (Table 5).

Not all species left the separator at the same time of day. Regression patterns for sockeye salmon revealed a distinct peak movement near 2000 hours each day (Appendix Fig. D3). Conversely, chinook salmon and steelhead tended to leave the separator at a more uniform rate over the course of the day (Appendix Figs. D1 and D2). The extent to which these patterns affected the sample rate is uncertain. However, we anticipate that results from the 1988 studies will provide valuable insight into this process. 


\section{SPILL CONDITION AT MCNARY DAM DURING EVALUATION PERIOD}

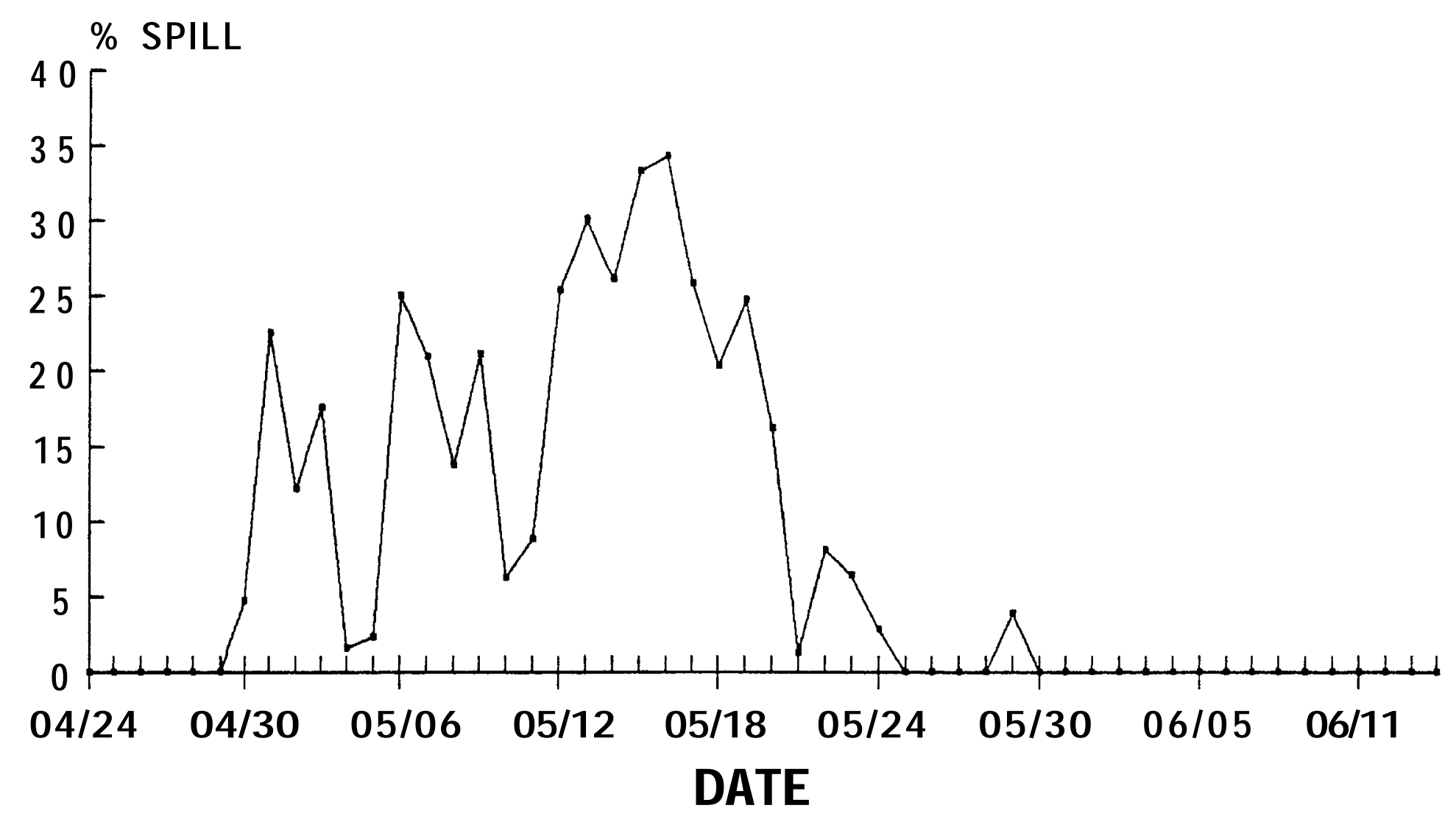




\section{MCNARY BRAND OBSERVATIONS FOR PRIEST RAPIDS SOCKEYE GROUPS 1 \& 3}

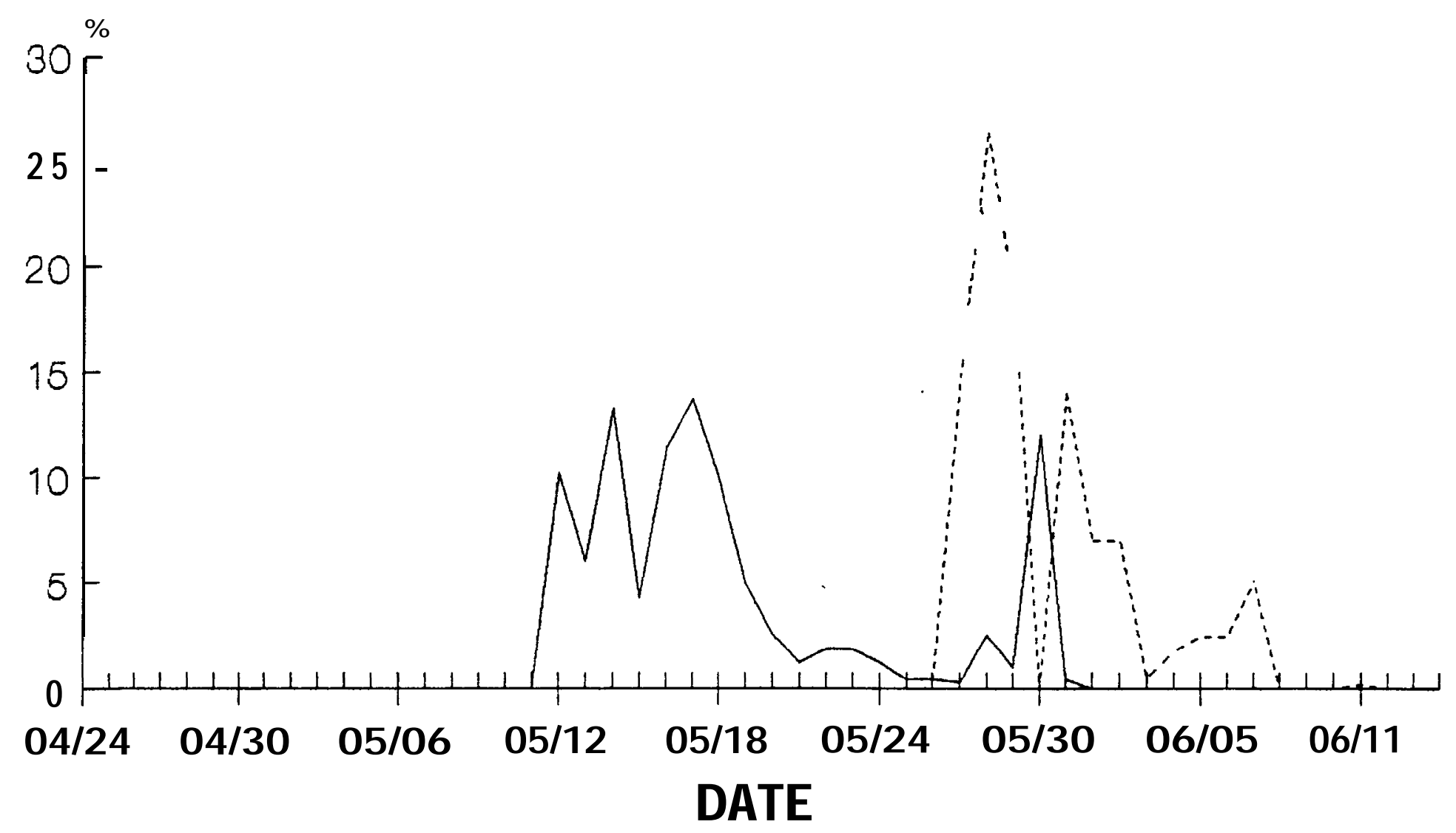

- L A W 2 -..... LA W 4

Figure 6 --Distribution of brand recoveries for two groups of river-run sockeye salmon released below Priest Rapids Dam and collected at McNary Dam in 1987. 


\section{SUMMARY AND CONCLUSIONS}

1) PIT-tagged stocks of yearling chinook salmon, sockeye salmon, and steelhead were consistently recovered in significantly greater proportions than freezebranded counterparts.

2) Brand recovery data for chinook and sockeye salmon were more variable than corresponding PIT-tag data.

3) The discrepancy between tag and brand recovery rates was not attributable to poor brand development.

4) Mistakes in the brand reading process were identified as one probable source of error which could account for some of the variability associated with recovery data for sockeye salmon.

5) Future research should address sources of error associated with the brand reading and subsampling process. An understanding of the extent of each source of error may enable managers to correct the deficiencies inherent in brand recovery data.

\section{ACKNOWLEDGMENTS}

Support for this research came from the region's electrical ratepayers through the Bonneville Power Administration.

We thank the hatchery staffs from Lyons Ferry Hatchery, Wells Hatchery, and Winthrop National Fish Hatchery for providing the fish used in this evaluation and for their assistance and cooperation during the marking and releasing of the various test groups.

We also offer our appreciation to the personnel of the Fish Passage Center; U.S. Fish and Wildlife Service (Fisheries Assistance Office, Vancouver WA); Washington Department of Fisheries; U.S. Army Corps of Engineers at McNary Dam; Grant County PUD at Priest Rapids Dam; and the NMFS fish sampling staff at McNary Dam for their assistance in this study. 


\section{LITERATURE CITED}

Dell, M, C. Carlson, R. Kindley, D. Park, S. Achord, C. McCutcheon, D. Weitkamp, R. Loeppke, R. Raleigh, and D. Chapman.

1985. Transportation Studies at Priest Rapids Dam 1984. Public Utility

District No. 2 of Grant County, Ephrata, Washington. 67 p. + Appendixes.

Fish Passage Center.

1988. Smolt Monitoring Program Annual Report 1987. Bonneville Power Administration, Project No. 87-127. 133 p. + Appendixes. Available from Fish Passage Center, 825 NE 20th Ave, Suite 336, Portland, OR 97232.

Giorgi, A. E., G. Swan, W. S. Zaugg, T. Coley, and T. Barila.

1988. Smolt Development in Yearling Chinook Salmon, Oncorhvnchus tshawytscha, and Susceptibility to Bypass Systems at Hydroelectric Dams, North Amer. Journal of Fisheries Management 8(1):26-29.

Jefferts, K. B., P. K. Bergman, and H. F. Fiscus.

1963. A coded wire identification system for Macro-organisms. Nature (Lond.) 198:460-462.

Matthews, D. L. Park, J. R. Harmon, and C. S. McCutcheon. 1987. Evaluation of Transportation of Juvenile Salmonids and Related Research on the Columbia and Snake Rivers, 1986. Report to U.S. Army Corps of Engineers, Contract DACW68-84-H-0034, 34 p. + Appendixes. Available from Northwest and Alaska Fisheries Center, 2725 Montlake Blvd. E., Seattle, Washington.

Mighell, J. L.

1969. Rapid cold-branding of salmon and trout with liquid nitrogen. J.

Fish. Res. Board Can. 26:2765-2769.

Prentice, E. F., T. A. Flagg, and C. S. McCutcheon.

1987. A Study to Determine the Biological Feasibility of a New Fish Tagging System, 1986-1987. Report to the Bonneville Power Administration, Contract DE-AI79-84BP11982.

Prentice, E. F., D. L. Park, T. A. Flagg, and C. S. McCutcheon.

1985. A Study to Determine the Biological Feasibility of a New Fish Tagging System, 1985-1986. NOAA, NMFS, Northwest and Alaska Fisheries Center, Seattle, Washington. Report to Bonneville Power Administration, Contract DE-AI79-84BP11982, 79 p. + Appendices.

Raymond, H. L.

1974. Marking Fish and Invertebrates. I. State of the art of fish branding. Mar. Fish. Rev. 36(1):1-9.

Rondorf, D. W., M. S. Dutchuk, A. S. Kolok, and M. L. Gross. 1985. Bioenergetics of juvenile salmon during the spring outmigration. Annual Report to Bonneville Power Admin., Portland, OR. 78 p. 
APPENDIX A

Summaries of PIT Tagging and Freeze Branding 


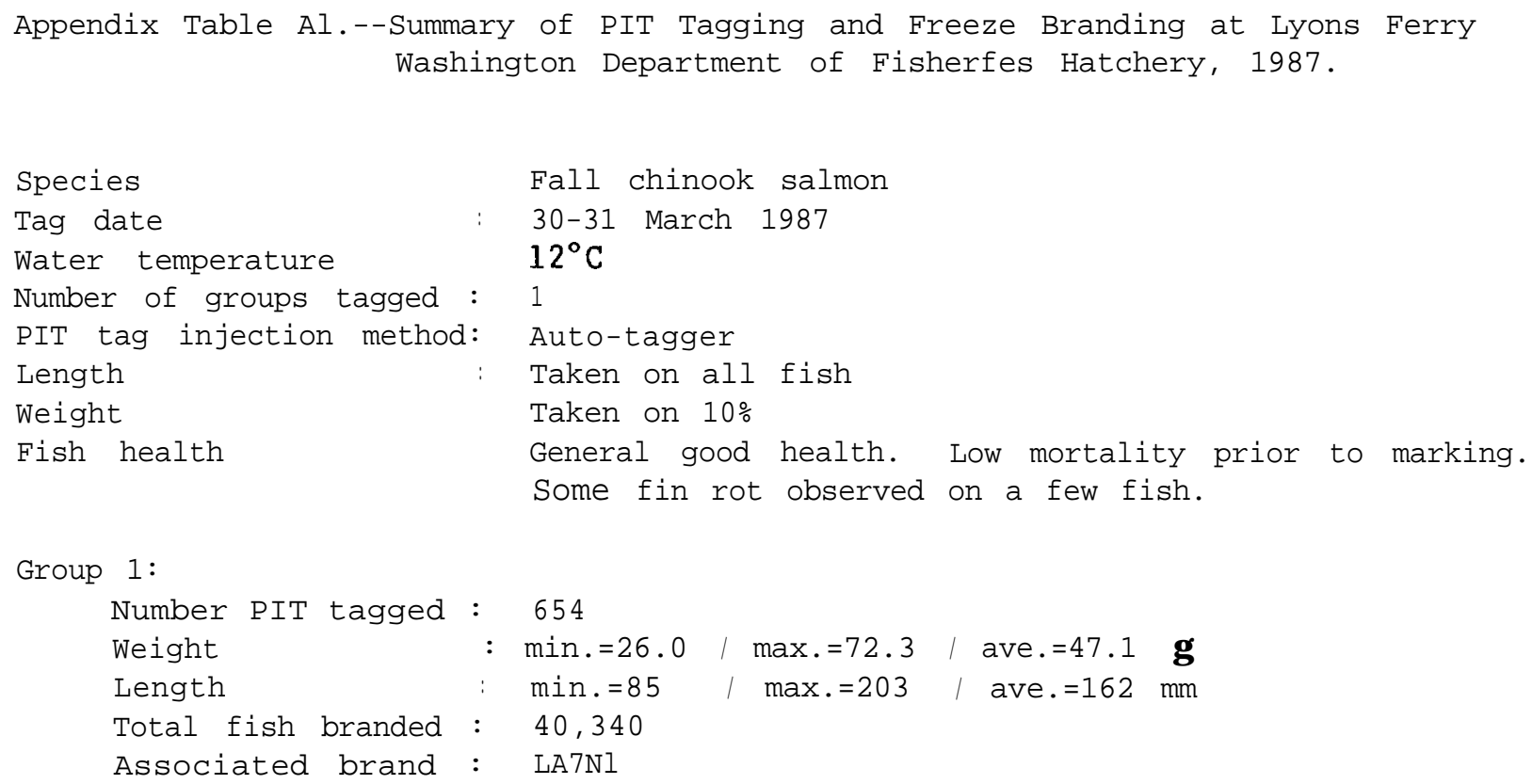




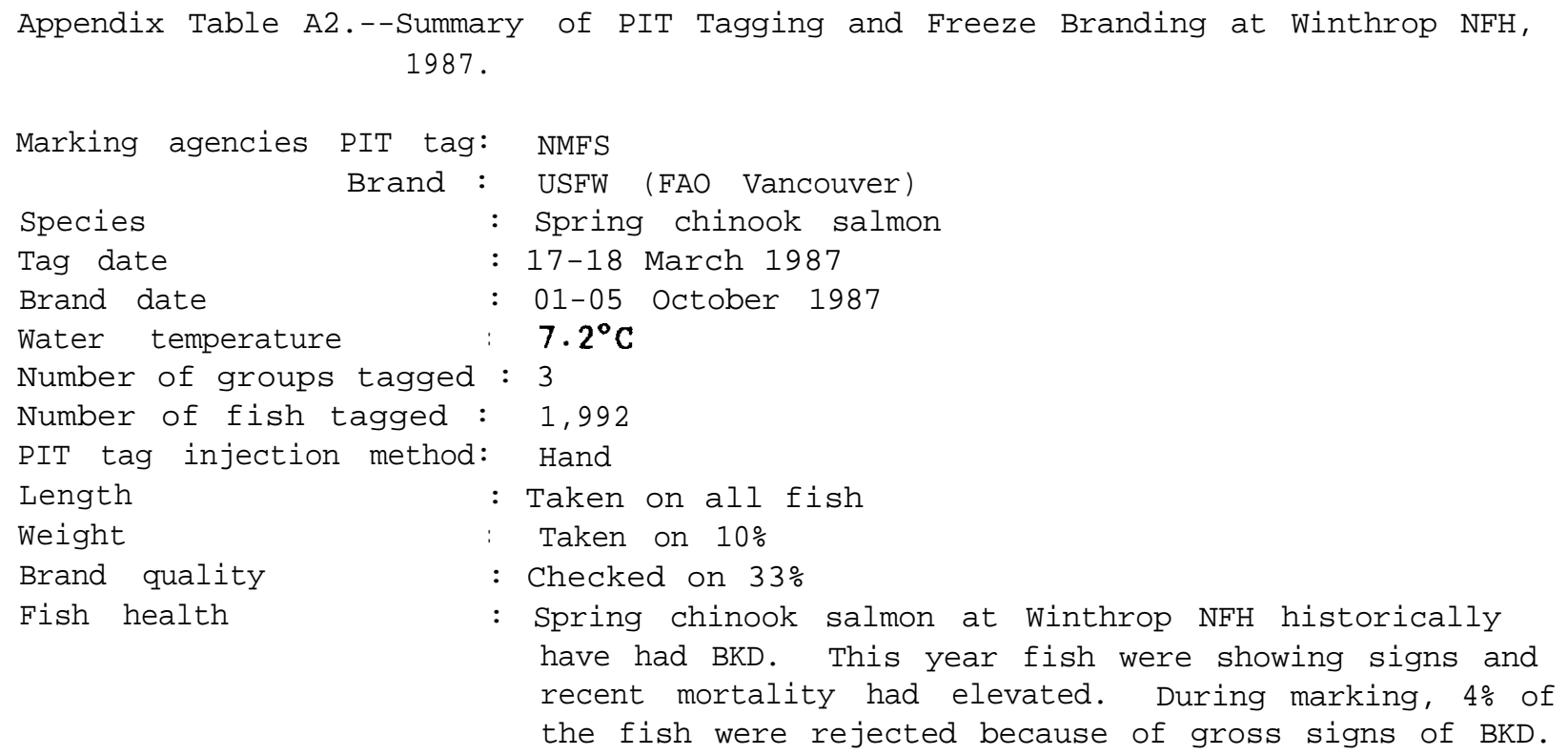




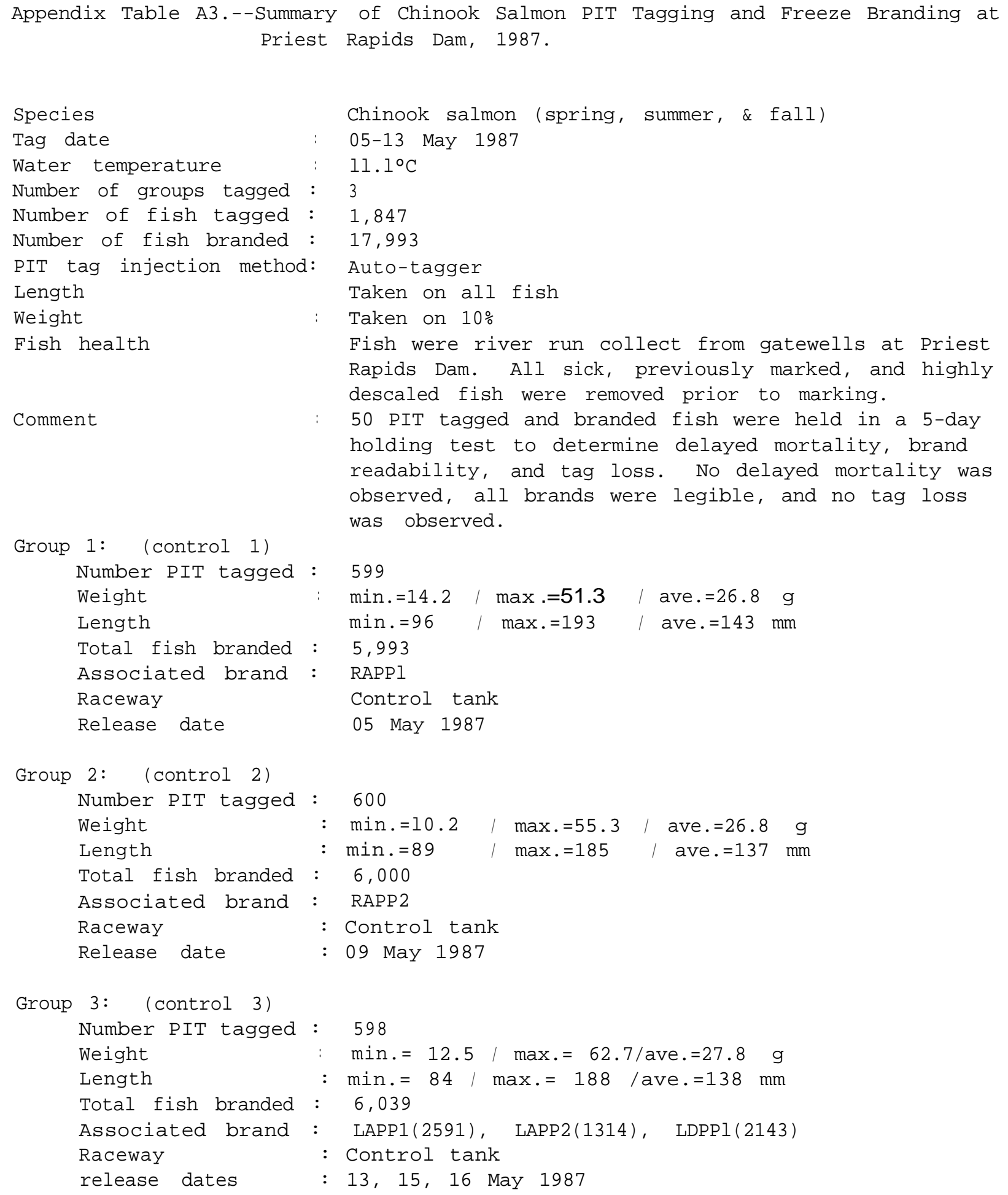




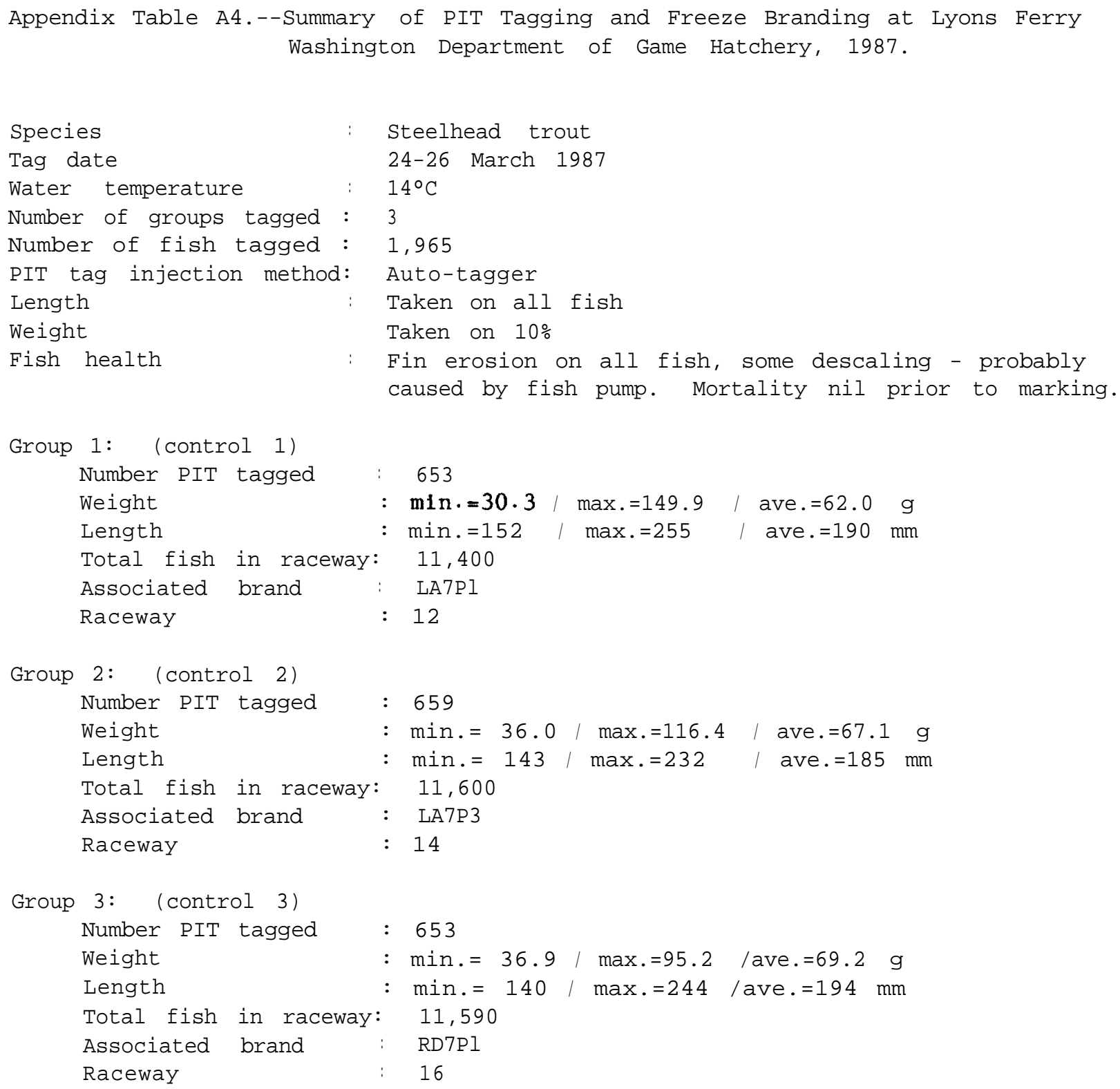




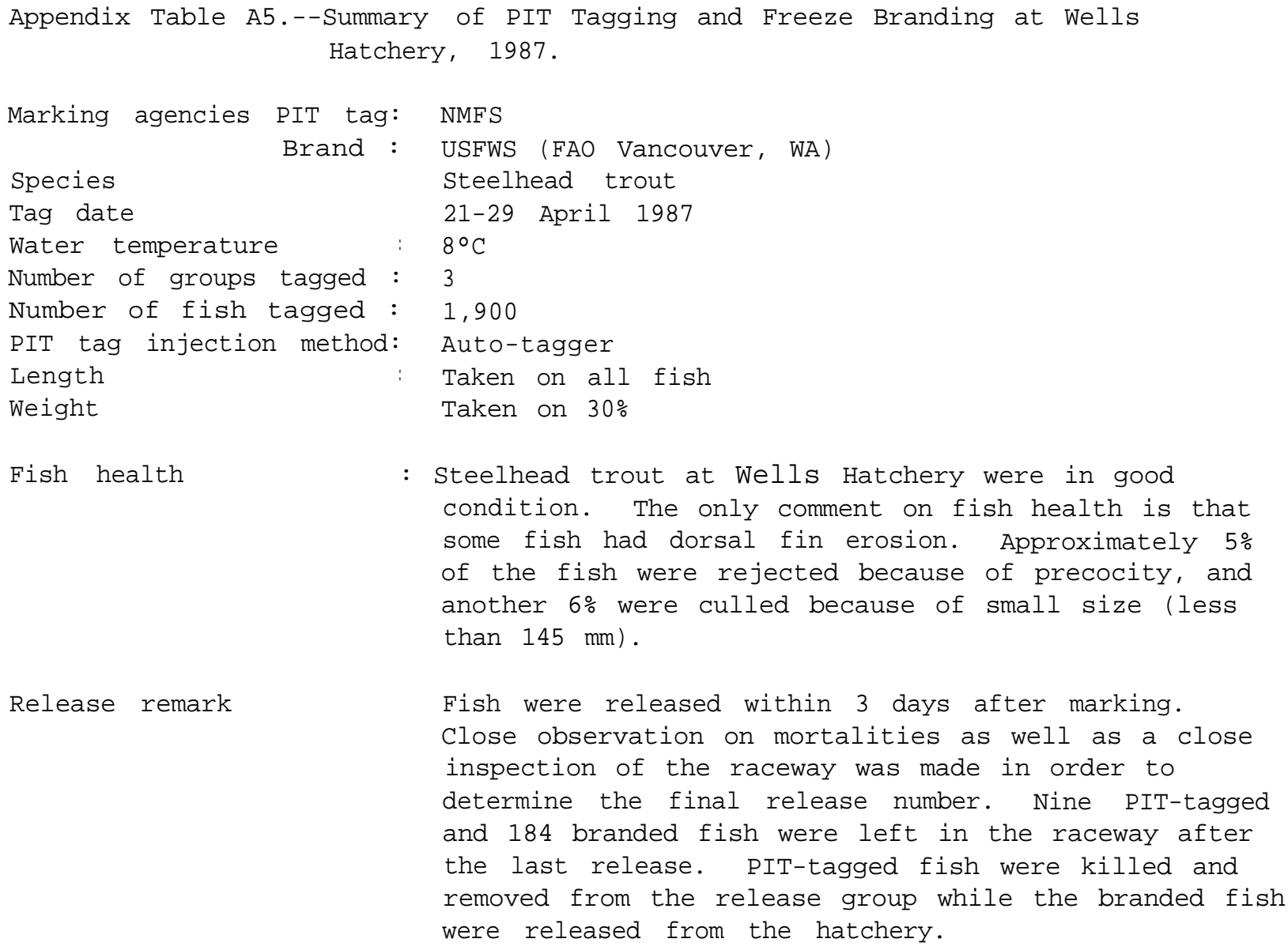




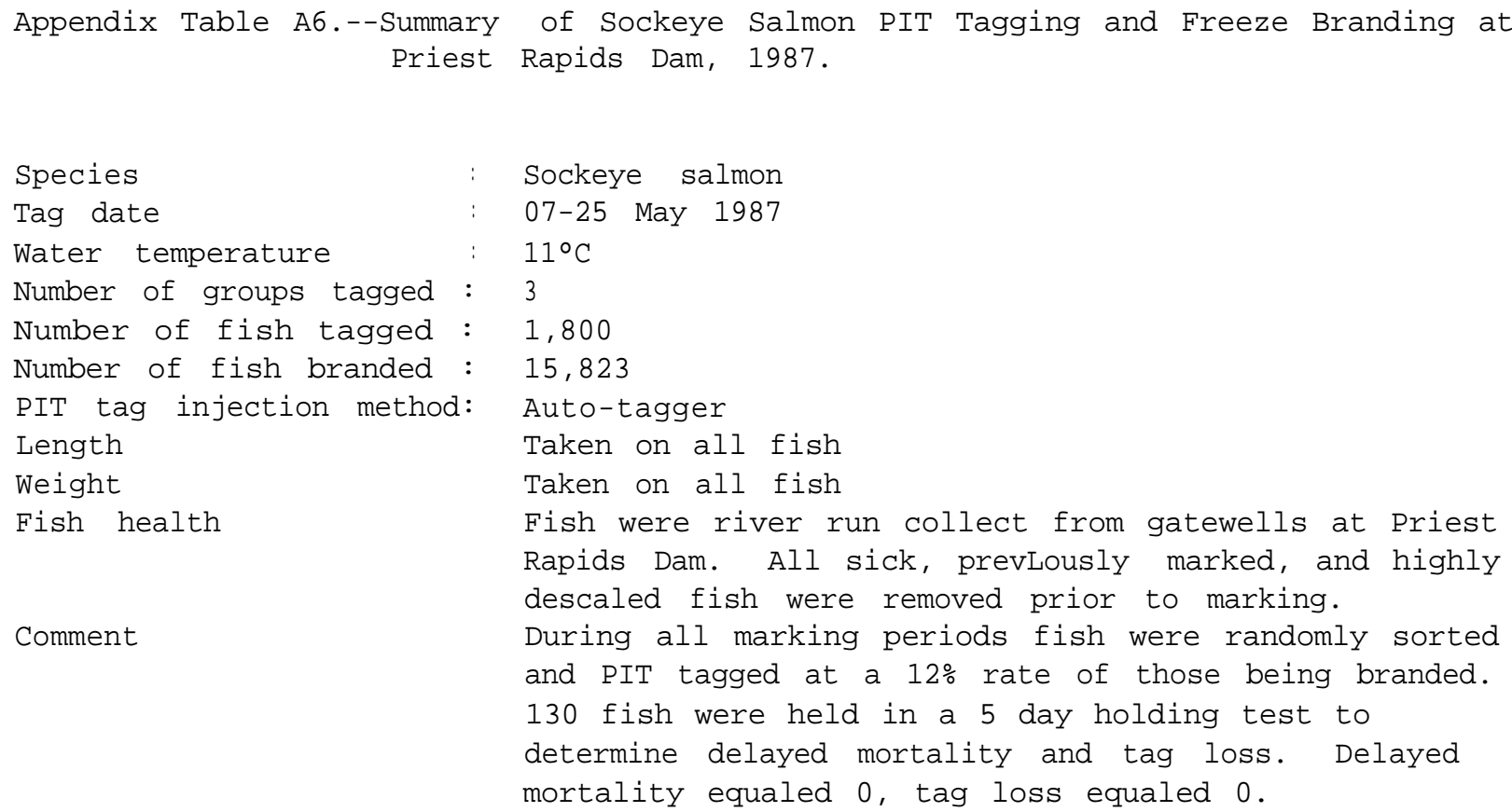


APPENDIX B

Summaries of Recovery Data 
Appendix Table Bl.--Summary of daily recovery data for yearling fall chinook salmon released from Lyons Ferry Hatchery, 1987.

Rel ease date: 14 Apr. 1987 Rel ease Ti ne: 1500 hours

Number branded fi sh rel eased: 39,312

Nunber PI T tagged fi sh rel eased: 597 (conf i rned)

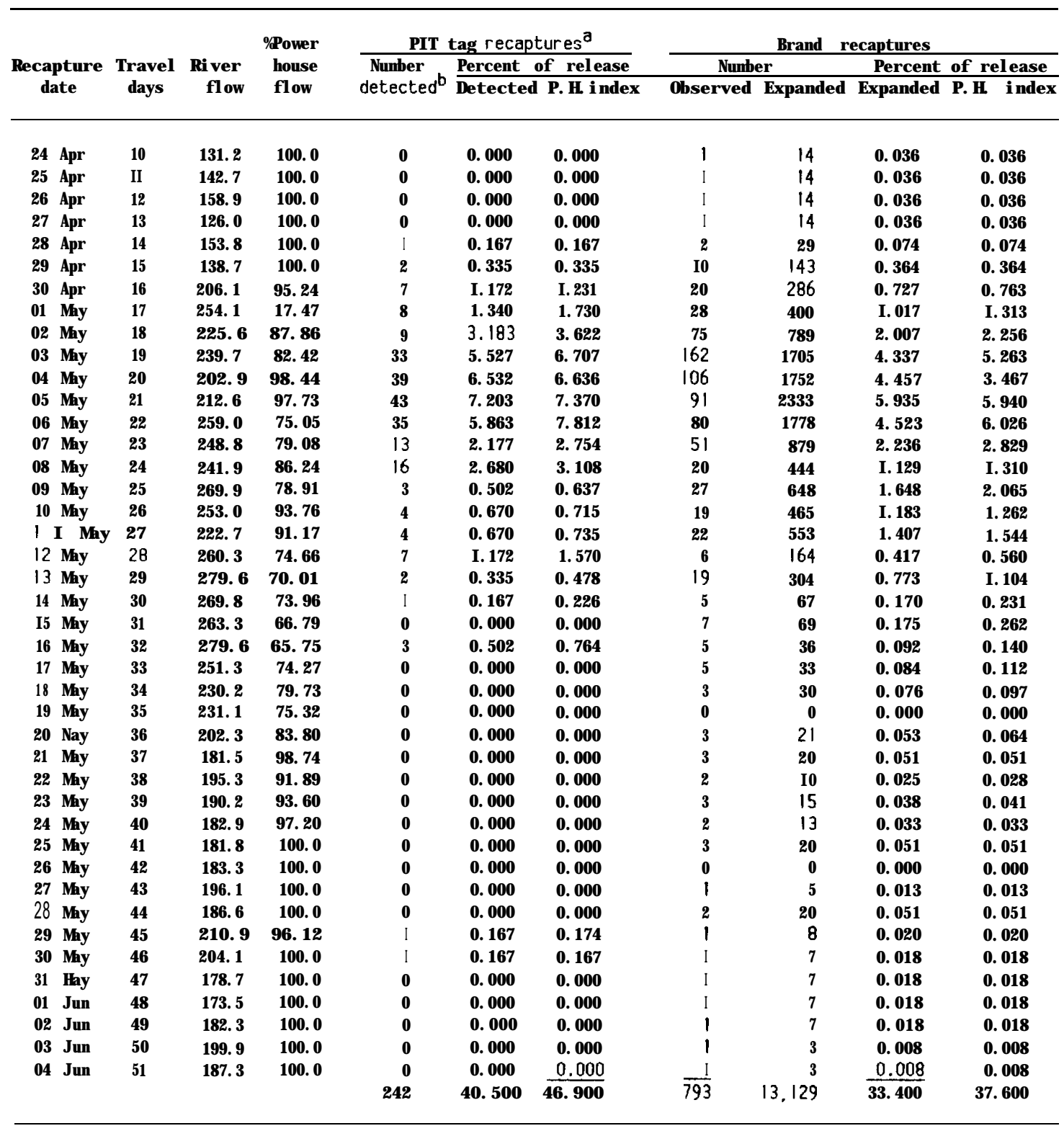

a PI T tag recapture dates (24-hour day midni ght to midni ght) have been shifted to match the brand date (noon to noon).

$b$ of the fish detected at the ti ne of rel ease. 
Appendix Table B2a.--Summary of daily recovery data for spring chinook salmon, group 1, released from Winthrop NFH, 1987.

Rel ease date: 20 April 1987 Rel ease ti ne: 1400 hours

Number branded $\mathrm{fI}$ sh rel eased: $\quad 10.658$

Nunber PI T tagged fi sh rel eased: 648(n) 303(c)

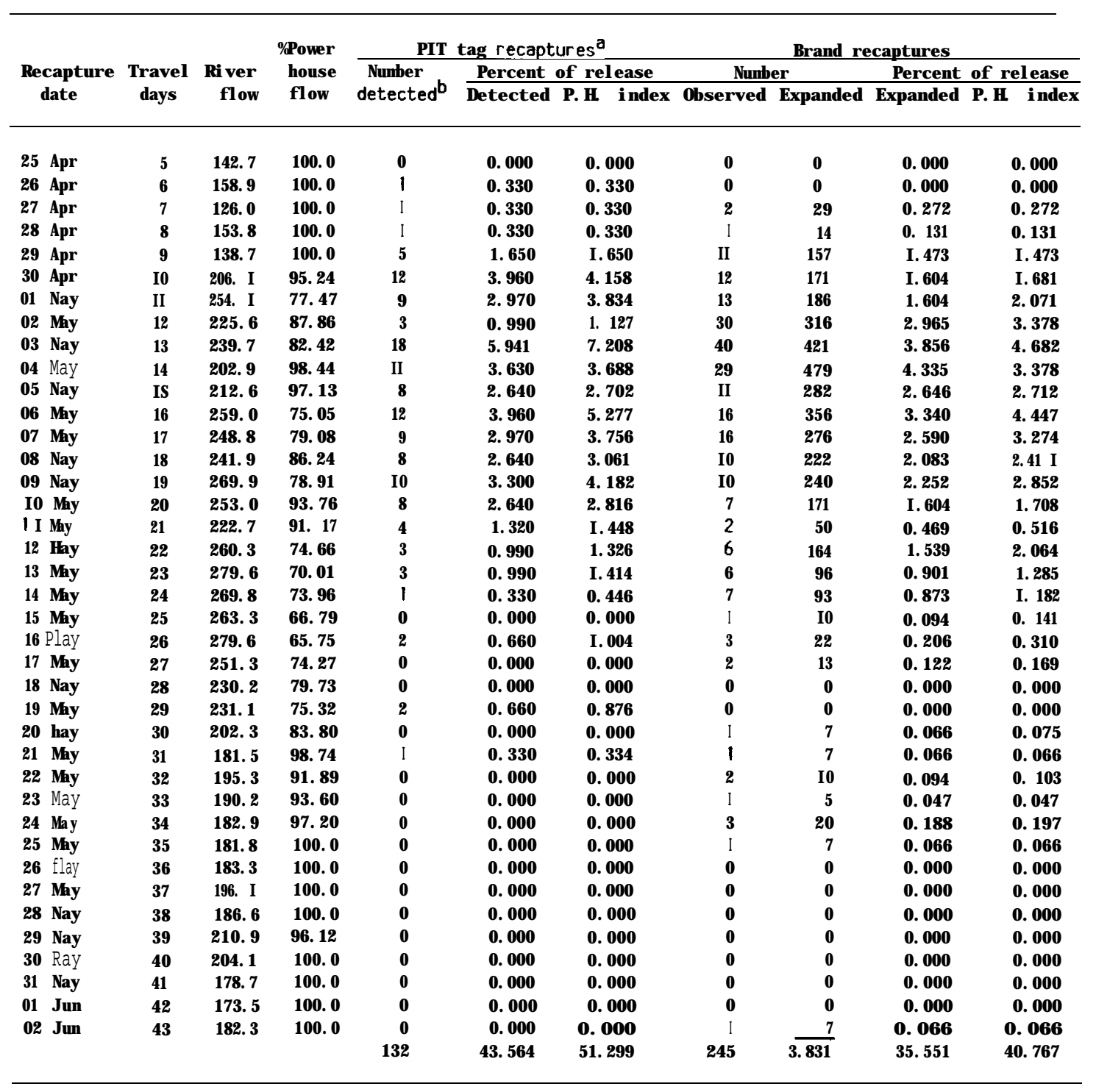

a PI t tag recapt ure dates (24-hour day midni ght to midni ght) have been shifted to match the brand date (noon to noon).

b of the fish detected at the ti ne of rel ease. 


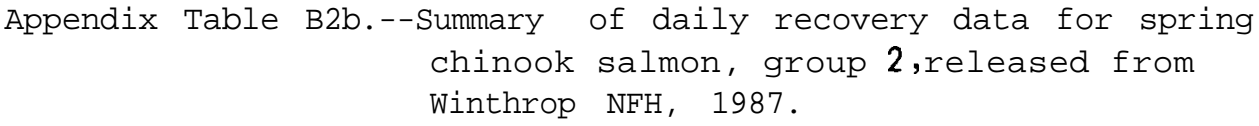

Rel ease date: 24 Apr 1987 Rel ease ti ne: 1400 hours

Nunber branded fi sh rel eased: 11, 028

Nunber PI T tagged fi sh rel eased: 641(n) $430(\mathrm{c})$

\begin{tabular}{|c|c|c|c|c|c|c|c|c|c|c|}
\hline \multirow{3}{*}{$\begin{array}{l}\text { Recapt ure } \\
\text { date }\end{array}$} & \multirow{3}{*}{$\begin{array}{c}\text { Travel } \\
\text { days }\end{array}$} & \multirow{3}{*}{$\begin{array}{l}\text { Ri ver } \\
\text { fl ow }\end{array}$} & \multirow{3}{*}{$\begin{array}{l}\text { \%poner } \\
\text { house } \\
\text { fl ow }\end{array}$} & \multicolumn{3}{|c|}{ PIT tag recaptures ${ }^{a}$} & \multicolumn{4}{|c|}{ Brand recapt ures } \\
\hline & & & & \multirow{2}{*}{$\begin{array}{l}\text { Nunber } \\
\text { detected }^{b}\end{array}$} & \multirow{2}{*}{\multicolumn{2}{|c|}{$\begin{array}{l}\text { Percent of rel ease } \\
\text { Detected P. H i ndex }\end{array}$}} & \multicolumn{2}{|c|}{ Nunber } & \multirow{2}{*}{$\begin{array}{r}\text { Percent } \\
\text { Expanded }\end{array}$} & \multirow{2}{*}{$\begin{array}{l}\text { of rel ease } \\
\text { P. } \mathrm{H} \text { i ndex }\end{array}$} \\
\hline & & & & & & & Observed & Expanded & & \\
\hline $28 \mathrm{Apr}$ & 4 & 153.8 & 100.0 & 0 & 0.000 & 0.000 & 0 & 0 & 0.000 & 0.000 \\
\hline $29 \mathrm{Apr}$ & 5 & 138.7 & 100.0 & 0 & 0.000 & 0.000 & 0 & 0 & 0.000 & 0.000 \\
\hline $30 \mathrm{Apr}$ & 6 & 206.1 & 95. 24 & 4 & 0.930 & 0.930 & 5 & 71 & 0.517 & 0.544 \\
\hline 01 May & 7 & 254.1 & 77. 47 & 7 & 1. 628 & 2. 093 & 10 & 143 & 1. 297 & 1.677 \\
\hline 02 My & 8 & 225.6 & 87.86 & 24 & 5. 581 & 6. 279 & 15 & 158 & 1.333 & I. 514 \\
\hline 03 May & 9 & 239.7 & 82.42 & 13 & 3. 023 & 3. 721 & 17 & 179 & 1.433 & I. 741 \\
\hline 04 May & 10 & 202.9 & 98.44 & 23 & 5. 349 & 5. 349 & 17 & 281 & 2.094 & 1. 632 \\
\hline $05 \mathrm{May}$ & II & 212.6 & 97.73 & 20 & 4. 651 & 4. 651 & 4 & 103 & 0.934 & 0.952 \\
\hline 06 May & 12 & 259.0 & 75.05 & 17 & 3. 953 & 5. 349 & 10 & 222 & 2. 013 & 2. 684 \\
\hline 07 My & 13 & 248.8 & 79.08 & 13 & 3. 023 & 3. 721 & 9 & 155 & 1. 405 & 1. 777 \\
\hline 08 May & 14 & 241.9 & 86. 24 & 13 & 3. 023 & 3. 488 & 9 & 200 & I. 813 & 2. 103 \\
\hline 09 My & 15 & 269.9 & 78. 91 & 13 & 3. 023 & 3. 721 & & 24 & 0.218 & 0.272 \\
\hline 10 May & 16 & 253.0 & 93. 76 & 10 & 2. 326 & 2. 558 & 8 & 196 & 1. 777 & 1. 895 \\
\hline II May & 17 & 222.7 & 91. 17 & 10 & 2. 326 & 2. 558 & 7 & 174 & 1. 596 & 1. 750 \\
\hline 12 Myy & 18 & 260.3 & 74. 66 & 3 & 0.698 & 0.930 & 3 & 82 & 0.743 & 0.997 \\
\hline $13 \mathrm{May}$ & 19 & 279. 6 & 70.01 & 6 & 1. 395 & 2.093 & 7 & 112 & 1.015 & I. 451 \\
\hline $14 \mathrm{May}$ & 20 & 269.8 & 73. 96 & । & 0.233 & 0.231 & & 13 & 0.118 & 0.163 \\
\hline $15 \mathrm{Mgy}$ & 21 & 263. 3 & 66.79 & i & 0.233 & 0.231 & 0 & 0 & 0.000 & 0.000 \\
\hline 16 May & 22 & 279.6 & 65.75 & 0 & 0.000 & 0.000 & 2 & 15 & 0.136 & 0.208 \\
\hline $17 \mathrm{May}$ & 23 & 251.3 & 74. 27 & 0 & 0.000 & 0.000 & 2 & 13 & 0.118 & 0.163 \\
\hline $18 \mathrm{May}$ & 24 & 230.2 & 79.73 & 0 & 0.000 & 0.000 & & 10 & 0.091 & 0.118 \\
\hline 19 May & 25 & 231. 1 & 75. 32 & 0 & 0.000 & 0.000 & 0 & 0 & 0.000 & 0.000 \\
\hline 20 May & 26 & 202.3 & 83. 80 & 0 & 0.000 & 0.000 & 2 & 14 & 0.127 & 0.154 \\
\hline 21 Ray & 27 & 181.5 & 98.74 & 0 & 0.000 & 0.000 & 0 & 0 & 0.000 & 0.000 \\
\hline $22 \mathrm{MAy}$ & 28 & 195.3 & 91.89 & 0 & 0.000 & 0.000 & 0 & 0 & 0.000 & 0.000 \\
\hline \multirow[t]{2}{*}{23 May } & 29 & 190.2 & 93.60 & $\underline{0}$ & 0.000 & 0.000 & 2 & 10 & 0.091 & 0.100 \\
\hline & & & & $\overline{178}$ & 41.390 & 47.907 & $\overline{132}$ & $2 \longdiv { 1 7 7 }$ & 18. 868 & 21. 897 \\
\hline
\end{tabular}

a PI T tag recapture dates ( 24 hour day mi dni ght to midni ght) have been shi fted to match the brand date (noon to noon).

b of the fi sh detected at the ti ne of rel ease. 


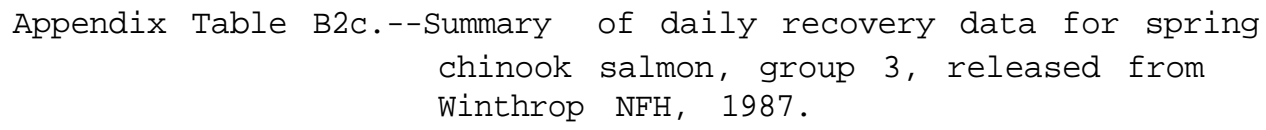

Rel ease date: 28 Apr 1987 Rel ease ti ne: 1400 hours

Number nranded fi sh rel eased: II. 300

Nunber PI T tagged fi sh rel eased: 667(n) 542(c)

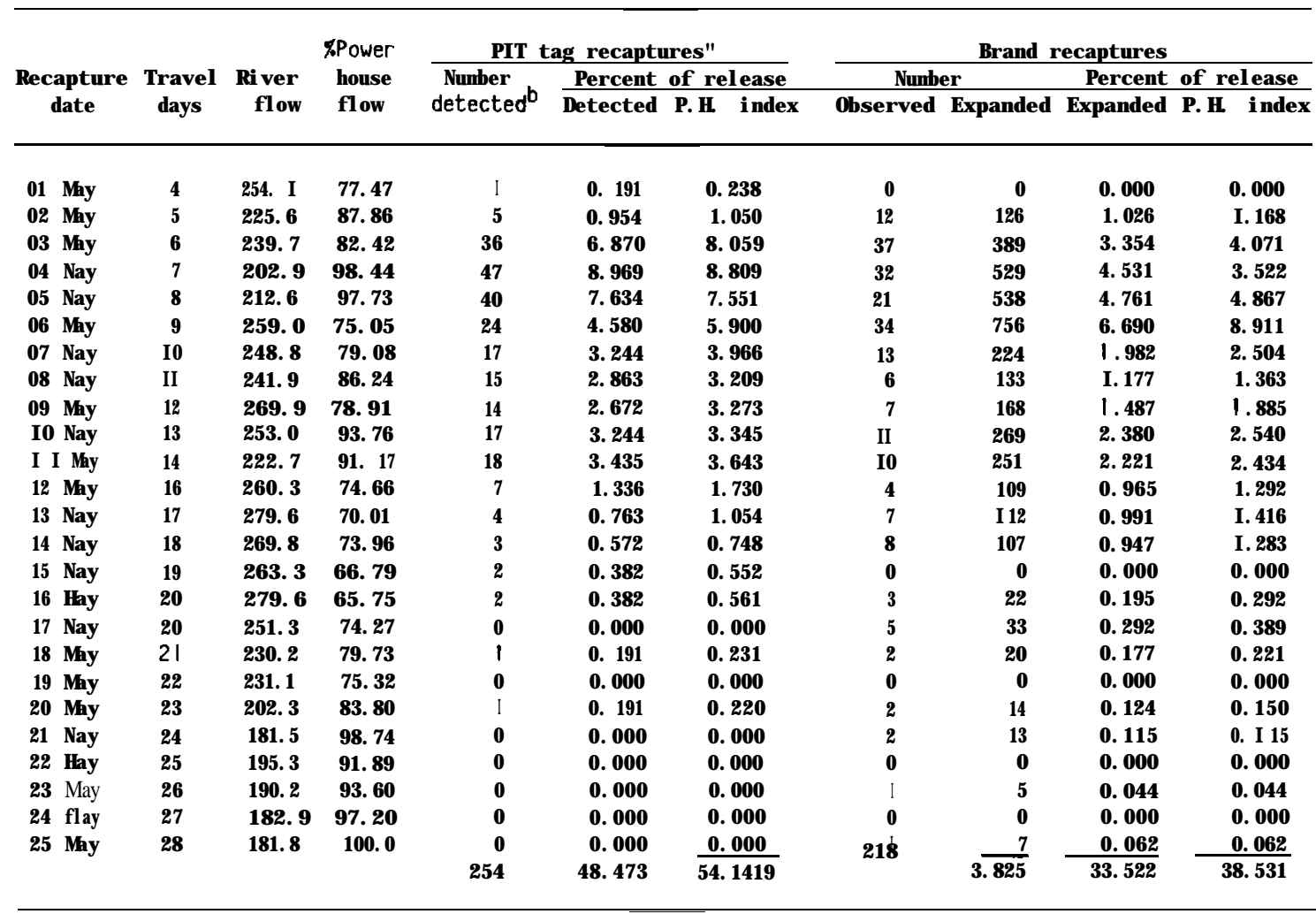

a PI T tag recapt ure dates (24-hour day midni ght to midni ght) have been shi fted to match the brand date (noon to noon).

b of the fish detected at the ti ne of rel ease. 
Appendix Table B3a.--Summary of daily recovery data for chinook
salmon group 1, released from Priest Rapids
Dam, 1987.

Rel ease date: 05 May 1987 Rel ease ti ne: 2300 hours Number branded fi sh rel eased: 5.993

Nunber PI T tagged fi sh rel eased: 599

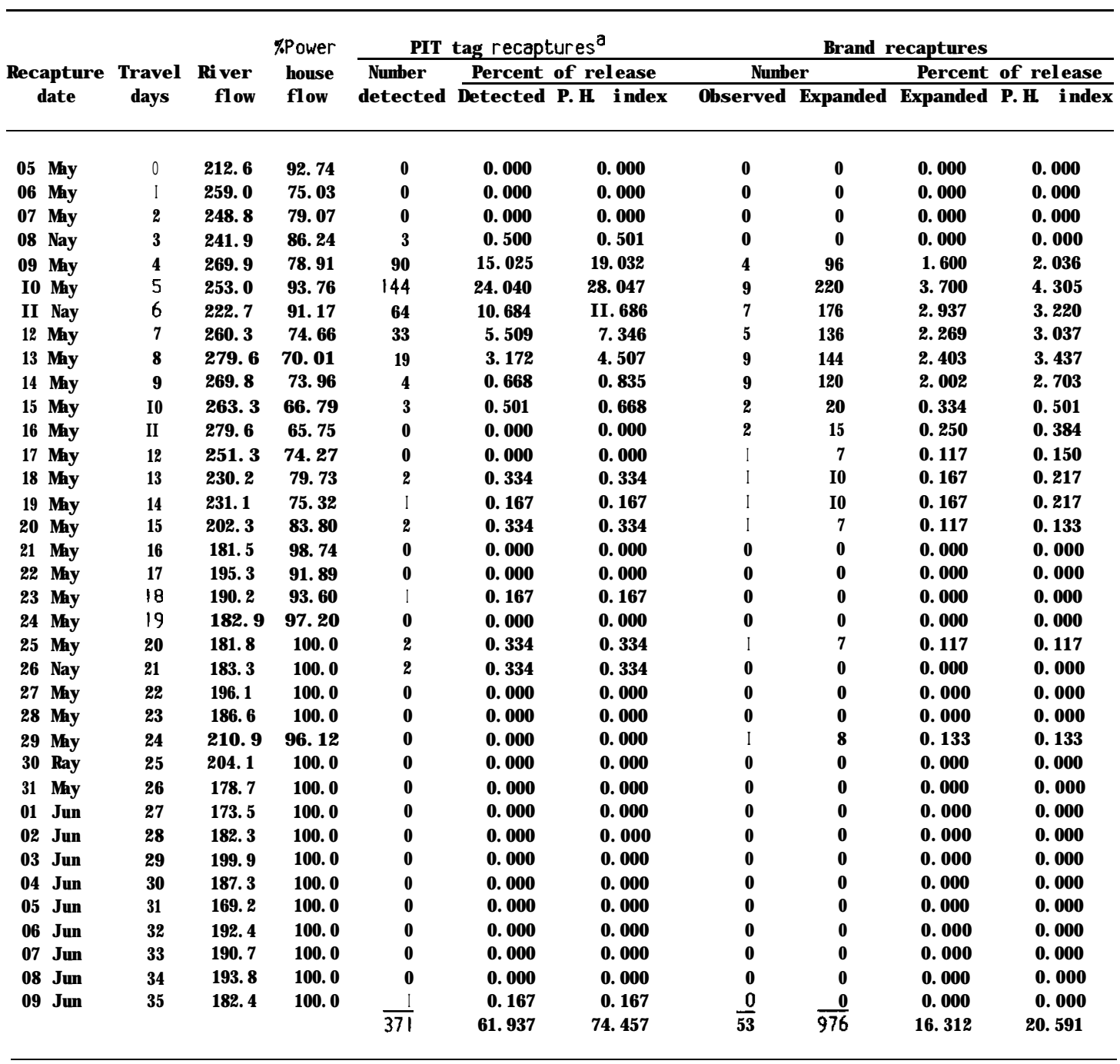

a PIT tag recapture dates (24-hour day midni ght to midni ght) have been shifted to match the brand date (noon to noon). 


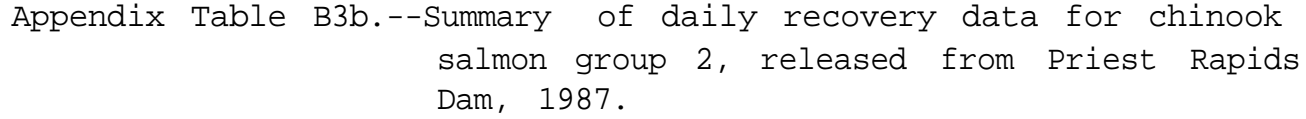

Rel ease date: 09 May 1987 Pelese tI me: 2300 hours

Nunber branded fi sh rel eased: 6, 000

Number PI T tagged fi sh rel eased: 600

\begin{tabular}{|c|c|c|c|c|c|c|c|c|c|c|c|}
\hline \multirow{3}{*}{$\begin{array}{l}\text { Recapt ure } \\
\text { date }\end{array}$} & \multirow{3}{*}{$\begin{array}{c}\text { Travel } \\
\text { days }\end{array}$} & \multirow{3}{*}{$\begin{array}{l}\text { Ri ver } \\
\text { fl ow }\end{array}$} & \multirow{3}{*}{$\begin{array}{l}\text { XPower } \\
\text { house } \\
\text { fl ow }\end{array}$} & \multicolumn{3}{|c|}{ PI T tag recaptures ${ }^{\mathrm{a}}$} & \multicolumn{5}{|c|}{ Brand recapt ures } \\
\hline & & & & \multirow{2}{*}{$\begin{array}{l}\text { Number } \\
\text { det ect ed }\end{array}$} & \multicolumn{2}{|c|}{ Percent of rel ease } & \multicolumn{2}{|c|}{ Nunber } & \multirow{2}{*}{$\begin{array}{r}\text { Percent } \\
\text { Expanded }\end{array}$} & \multicolumn{2}{|c|}{ or rel ease } \\
\hline & & & & & Det ect ed & P. H i ndex & Observed & Expanded & & P. H & i ndex \\
\hline 09 flay & 0 & 269.9 & 78.91 & 0 & 0.000 & 0.000 & 0 & 0 & 0.000 & & 0.000 \\
\hline 10 May & 1 & 253.0 & 93.76 & $\mathbf{0}$ & 0.000 & 0.000 & 0 & 0 & 0.000 & & 0.000 \\
\hline 11 May & 2 & 222.7 & 91.17 & 0 & 0.000 & 0.000 & 0 & 0 & 0.000 & & 0.000 \\
\hline 12 May & 3 & 260.3 & 74.66 & 0 & 0.000 & 0.000 & $\mathbf{0}$ & 0 & 0.000 & & 0.000 \\
\hline 13 Hay & 5 & 279.6 & 70.01 & 45 & 7.500 & 10.667 & 5 & 80 & 1. 333 & & 1.900 \\
\hline $14 \mathrm{May}$ & 6 & 269.8263 .3 & 66.7973 .96 & 184 & 30.667 & 41. 333 & 81 & 1080 & 18. 000 & & 24. 333 \\
\hline 15 May & & & & 60 & 10.000 & 14. 833 & 41 & 406 & 6. 167 & & 10.133 \\
\hline 16 May & 7 & 279.6 & 65.75 & 24 & 4.000 & 6.000 & 35 & 255 & 4. 250 & & 6.467 \\
\hline 17 May & 8 & 251.3 & 74. 27 & 8 & 1. 333 & 1. 667 & 25 & 167 & 2.783 & & 3.750 \\
\hline $18 \mathrm{flay}$ & 9 & 230.2 & 79.73 & 9 & 1.500 & 1.833 & 12 & 120 & 2.000 & & 2. 517 \\
\hline 19 Nay & 10 & 231.1 & 75. 32 & 9 & 1. 500 & 2. 000 & 3 & 30 & 0.500 & & 0.667 \\
\hline 20 May & II & 202.3 & 83.80 & I & 0.167 & 0.167 & 4 & 27 & 0.450 & & 0.533 \\
\hline 21 May & 12 & 181.5 & 98.74 & 5 & 0.833 & 0.833 & 2 & 13 & 0.217 & & 0.217 \\
\hline 22 Hy & 13 & 195.3 & 91.89 & 1 & 0.167 & 0.167 & 2 & 10 & 0. 167 & & 0.183 \\
\hline 23 Hy & 14 & 190.2 & 93.60 & 1 & 0.167 & 0.167 & 0 & 0 & 0.000 & & 0.000 \\
\hline 24 May & 15 & 182.9 & 97.20 & 0 & 0.000 & 0.000 & 1 & 7 & 0.117 & & 0.117 \\
\hline 25 May & 16 & 181.8 & 100.0 & 0 & 0.000 & 0.000 & 0 & 0 & 0.000 & & 0.000 \\
\hline 26 May & 17 & 183.3 & 100.0 & I & 0.167 & 0.167 & 0 & 0 & 0.000 & & 0.000 \\
\hline 27 May & 18 & 196. 1 & 100.0 & 0 & 0.000 & 0.000 & 0 & 0 & 0.000 & & 0.000 \\
\hline 28 May & 19 & 186.6 & 100.0 & 0 & 0.000 & 0.000 & 0 & 0 & 0.000 & & 0.000 \\
\hline 29 Nay & 20 & 210.9 & 96.12 & 0 & 0.000 & 0.000 & 0 & 0 & 0.000 & & 0.000 \\
\hline 30 Why & 21 & 204. 1 & 100.0 & 0 & 0.000 & 0.000 & 0 & 0 & 0.000 & & 0.000 \\
\hline 31 Hay & 22 & 178.7 & 100.0 & 0 & 0.000 & 0.000 & 0 & 0 & 0.000 & & 0.000 \\
\hline $01 \mathrm{~J}$ un & 23 & 173.5 & 100.0 & 1 & 0.167 & 0.167 & 0 & 0 & 0.000 & & 0.000 \\
\hline $02 \mathrm{~J}$ un & 24 & 182.3 & 100.0 & 0 & 0.000 & 0.000 & 0 & 0 & 0.000 & & 0.000 \\
\hline $03 \mathrm{~J}$ un & 25 & 199.9 & 100.0 & 0 & 0.000 & 0.000 & 0 & 0 & 0.000 & & 0.000 \\
\hline $04 \mathrm{~J}$ un & 26 & 187.3 & 100.0 & 0 & 0.000 & 0.000 & 0 & 0 & 0.000 & & 0.000 \\
\hline $05 \mathrm{~J}$ un & 27 & 169.2 & 100.0 & 1 & 0.167 & 0.167 & 0 & 0 & 0.000 & & 0.000 \\
\hline $06 \mathrm{~J}$ un & 28 & 192.4 & 100.0 & 0 & 0.000 & 0.000 & 0 & 0 & 0.000 & & 0.000 \\
\hline $07 \mathrm{~J}$ un & 29 & 190.7 & 100.0 & 0 & 0.000 & 0.000 & 0 & 0 & 0.000 & & 0.000 \\
\hline $08 \mathrm{~J}$ un & 30 & 194.0 & 100.0 & 0 & 0.000 & 0.000 & 0 & 0 & 0.000 & & 0.000 \\
\hline \multirow[t]{2}{*}{$09 \mathrm{~J}$ un } & 31 & 182.4 & 100.0 & 1 & 0.167 & 0.167 & $\underline{0}$ & $\underline{0}$ & 0.000 & & 0.000 \\
\hline & & & & $\overline{351}$ & 58.500 & 80. 333 & 211 & 2. 195 & 36. 583 & & 50.817 \\
\hline
\end{tabular}

a PI T tag recapture dates (24-hour day midni ght to midni ght) have been shifted to match the brand date (noon to noon). 
Appendix Table B3c.--Summary of daily recovery data for chinook aalmon group 3, released from Priest Rapids Dam, 1987.

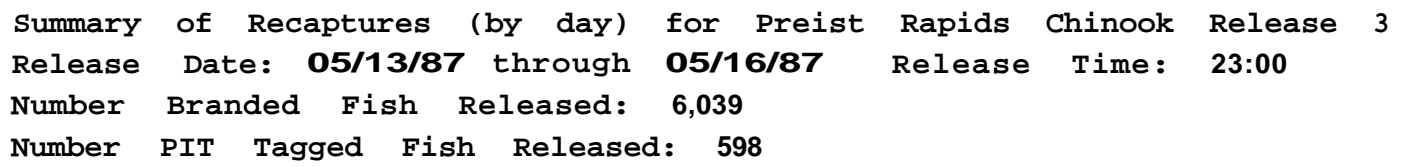

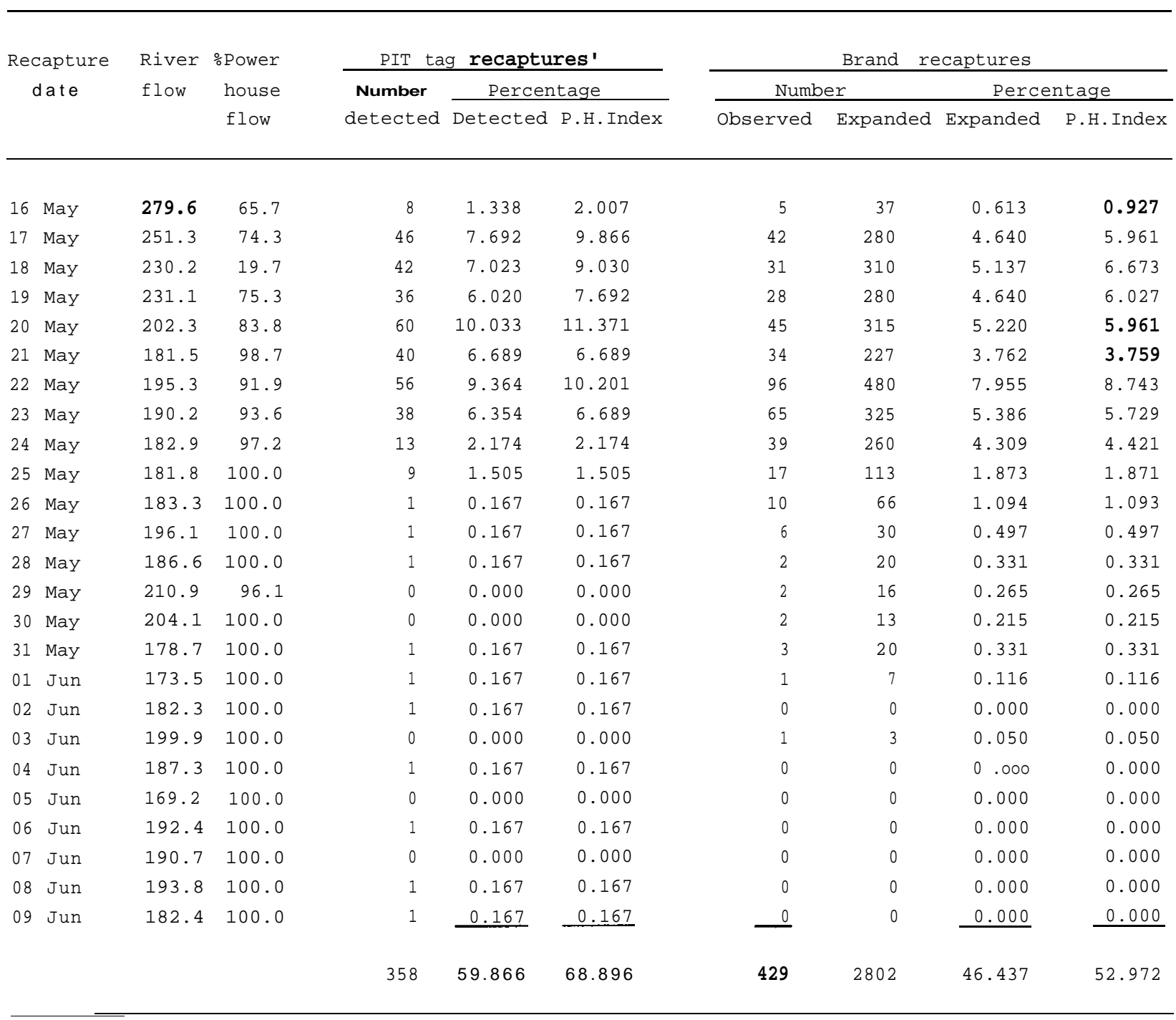

\footnotetext{
1 PIT tag recapture dates (24 hour day midnight to midnight) have been shifted to match the brand date (noon to noon).
} 


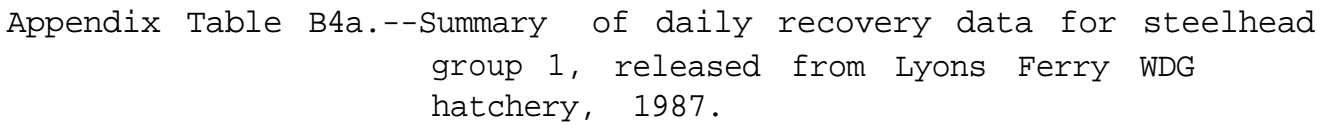

Rel ease date: $04 / 23 / 87$ Rel ease ti ne: 1300 hours

Number branded fi sh rel eased: 11, 279

Number PI T tagged fi sh rel eased: $650(\mathrm{n}) \quad 421(\mathrm{c})$

\begin{tabular}{|c|c|c|c|c|c|c|c|c|c|c|}
\hline \multirow{3}{*}{$\begin{array}{l}\text { Recapt ure } \\
\text { date }\end{array}$} & \multirow{3}{*}{$\begin{array}{c}\text { Travel } \\
\text { days }\end{array}$} & \multirow{3}{*}{$\begin{array}{l}\text { Ri ver } \\
\text { fl ow }\end{array}$} & \multirow{3}{*}{$\begin{array}{l}\text { YPower } \\
\text { house } \\
\text { fl ow }\end{array}$} & \multicolumn{3}{|c|}{ PIT tag recaptures ${ }^{\mathrm{a}}$} & \multicolumn{4}{|c|}{ Brand recaptures } \\
\hline & & & & \multirow{2}{*}{$\begin{array}{l}\text { Nunber } \\
\text { detected }^{b}\end{array}$} & \multirow{2}{*}{$\frac{\text { Percent }}{\text { Det ected }}$} & \multirow{2}{*}{$\begin{array}{l}\text { of } \text { rel ease } \\
\text { P. } \mathrm{H} \text { i ndex }\end{array}$} & \multicolumn{2}{|c|}{ Nunber } & \multirow{2}{*}{$\begin{array}{c}\text { Percent } \\
\text { Expanded }\end{array}$} & \multirow{2}{*}{$\begin{array}{l}\text { of rel ease } \\
\text { P. } \mathrm{H} \text { i ndex }\end{array}$} \\
\hline & & & & & & & Observed & Expanded & & \\
\hline 26 Apr & 3 & & & 1 & 0.237 & 0.237 & 5 & 71 & 0.629 & 0.629 \\
\hline $27 \mathrm{Apr}$ & 4 & 266.0158 .9 & 100.0100 .0 & 2 & 0.475 & 0.475 & 5 & 71 & 0.629 & 0.629 \\
\hline $28 \mathrm{Apr}$ & 5 & 153.8 & 100.0 & 9 & 2. 138 & 2. 138 & 17 & 243 & 2. 154 & 2. 154 \\
\hline $29 \mathrm{Apr}$ & 6 & 138.7 & 100.0 & 14 & 3. 325 & 3. 325 & 23 & 329 & 2. 917 & 2. 917 \\
\hline $30 \mathrm{Apr}$ & 7 & 206.1 & 95.24 & 19 & 4. 513 & 4. 739 & 46 & 657 & 5. 825 & 5. 985 \\
\hline 01 May & 8 & 254.1 & 77.47 & 21 & 4. 988 & 6.439 & 31 & 443 & 3. 928 & 4. 823 \\
\hline 02 flay & 9 & 225.6 & 87.86 & 8 & 1.900 & 2. 163 & 22 & 232 & 2. 057 & 2. 252 \\
\hline 03 flay & 10 & 239.7 & 82.42 & 7 & 1.663 & 2. 017 & 15 & 158 & I. 401 & 1. 702 \\
\hline 04 May & 11 & 202.9 & 98.44 & 7 & 1. 663 & 1. 689 & 7 & 191 & 1. 693 & 0.798 \\
\hline 05 May & 12 & 212.6 & 97.73 & 7 & 1.663 & 1. 701 & 3 & 77 & 0.683 & 0.700 \\
\hline 06 May & 13 & 259.0 & 75.05 & 5 & I. 188 & 1. 582 & 4 & 89 & 0.789 & 1. 055 \\
\hline 07 flay & 14 & 248.8 & 79.08 & I & 0.237 & 0.300 & 3 & 52 & 0.461 & 0.585 \\
\hline 08 May & 15 & 241.9 & 86.24 & I & 0.237 & 0.275 & 5 & III & 0.984 & 1. 144 \\
\hline $09 \mathrm{flay}$ & 16 & 269.9 & 78. 91 & 4 & 0.950 & 1. 204 & 2 & 48 & 0.426 & 0.541 \\
\hline 10 May & 17 & 253.0 & 93.76 & I & 0.237 & 0.253 & 3 & 73 & 0.647 & 0.691 \\
\hline II Nay & 18 & 222.7 & 91. 17 & I & 0.237 & 0.260 & 3 & 75 & 0.665 & 0.727 \\
\hline 12 May & 19 & 260.3 & 74.66 & 2 & 0.475 & 0.636 & 0 & 0 & 0.000 & 0.000 \\
\hline 13 May & 20 & 279.6 & 70.01 & I & 0.237 & 0.339 & 4 & 64 & 0.567 & 0.807 \\
\hline 14 May & 21 & 269.8 & 73. 96 & 0 & 0.000 & 0.000 & 1 & 13 & 0.115 & 0.160 \\
\hline IS Hy & 22 & 263.3 & 66.79 & 0 & 0.000 & 0.000 & 2 & 20 & 0.177 & 0.266 \\
\hline 16 May & 23 & 279.6 & 65.75 & 0 & 0.000 & 0.000 & 2 & 15 & 0.133 & 0.204 \\
\hline 17 Hay & 24 & 251.3 & 74.27 & 2 & 0.475 & 0.639 & 0 & 0 & 0.000 & 0.000 \\
\hline 18 May & 25 & 230.2 & 79.73 & 0 & 0.000 & 0.000 & 1 & 10 & 0.089 & 0.115 \\
\hline 19 May & 26 & 231.1 & 75. 32 & 0 & 0.000 & 0.000 & 1 & 10 & 0.089 & 0.115 \\
\hline 20 May & 27 & 202.3 & 83.80 & 0 & 0.000 & 0.000 & I & 7 & 0.062 & 0.071 \\
\hline 21 May & 28 & 181.5 & 98.74 & 0 & 0.000 & 0.000 & 0 & 0 & 0.000 & 0.000 \\
\hline 22 May & 29 & 195.3 & 91.89 & 0 & 0.000 & 0.000 & 0 & 0 & 0.000 & 0.000 \\
\hline 23 Hay & 30 & 190.2 & 93.60 & 0 & 0.000 & 0.000 & 0 & 0 & 0.000 & 0.000 \\
\hline 24 Ray & 31 & 182.9 & 97.20 & 1 & 0.237 & 0.244 & 0 & 0 & 0.000 & 0.000 \\
\hline $04 \mathrm{~J}$ un & 42 & 187.3 & 100.0 & 0 & 0.000 & 0.000 & I & 3 & 0.027 & 0.027 \\
\hline $09 \mathrm{~J}$ un & 46 & 182.4 & 100.0 & 1 & 0.237 & 0.237 & 0 & 0 & 0.000 & 0.000 \\
\hline \multirow{2}{*}{$18 \mathrm{~J}$ un } & 54 & - & - & 1 & 0.237 & 0.000 & 0 & $\underline{0}$ & 0.000 & 0.000 \\
\hline & & & & $\mathbf{i}-\mathbf{z}$ & 27. 553 & 30.897 & 207 & 3,062 & 27. 148 & 29. 098 \\
\hline
\end{tabular}

a PIT tag recapture dates (24-hour day midni ght to midni ght) have been shi fted to match the brand date (noon to noon).

$b$ of the fish detected at the ti ne of rel ease. 
Appendix Table B4b.--Summary of daily recovery data for steelhead group 2, released from Lyons Ferry WDG

hatchery, 1987.

Rel ease date: 27 Apr 1987 Rel ease ti ne: 1300 hours

Number branded fi sh rel eased: 11.478

Number PI T tagged fi sh rel eased: 647(n) 533(c)

\begin{tabular}{|c|c|c|c|c|c|c|c|c|c|c|}
\hline \multirow{3}{*}{$\begin{array}{l}\text { Recapt ure } \\
\text { date }\end{array}$} & \multirow{3}{*}{$\begin{array}{l}\text { Travel } \\
\text { days }\end{array}$} & \multirow{3}{*}{$\begin{array}{l}\text { Ri ver } \\
\text { fl ow }\end{array}$} & \multirow{3}{*}{$\begin{array}{l}\text { \%Power } \\
\text { house } \\
\text { fl ow }\end{array}$} & \multicolumn{3}{|c|}{ PI T tag recaptures ${ }^{a}$} & \multicolumn{4}{|c|}{ Brand recaptures } \\
\hline & & & & \multirow{2}{*}{$\begin{array}{c}\text { Number } \\
\text { detected }^{b}\end{array}$} & \multirow{2}{*}{\multicolumn{2}{|c|}{$\frac{\text { Percent of rel ease }}{\text { Detected P. H i ndex }}$}} & \multicolumn{2}{|c|}{ Nunber } & \multirow{2}{*}{ Percent } & \multirow{2}{*}{$\begin{array}{l}\text { of rel ease } \\
\text { P. } \mathrm{H} \text { i ndex }\end{array}$} \\
\hline & & & & & & & Observed & Expanded & & \\
\hline $29 \mathrm{Apr}$ & 2 & 138.7 & 100.0 & 0 & 0.000 & 0.000 & 0 & 0 & 0.000 & 0.000 \\
\hline $30 \mathrm{Apr}$ & 3 & 206. 1 & 95.24 & 17 & 3. 189 & 3. 349 & 8 & 114 & 0.993 & 1. 045 \\
\hline 01 May & 4 & 254.1 & 77.47 & 28 & 5. 253 & 6.781 & 19 & 271 & 2. 361 & 3. 049 \\
\hline 02 May & 5 & 225.6 & 87.86 & 16 & 3. 002 & 3. 417 & 28 & 295 & 2. 570 & 2. 718 \\
\hline 03 May & 6 & 239.7 & 82.42 & 15 & 2. 814 & 3. 414 & 24 & 253 & 2. 204 & 2. 561 \\
\hline 04 nay & 7 & 202.9 & 98.44 & 16 & 3. 002 & 3. 049 & II & 301 & 2. 622 & 0.897 \\
\hline 05 May & 8 & 212.6 & 97.73 & 12 & 2. 251 & 2. 304 & 2 & 51 & 0.444 & 0.453 \\
\hline 06 Hby & 9 & 259.0 & 75.05 & 7 & I. 313 & 1. 750 & 7 & 156 & 1. 359 & I. 812 \\
\hline 07 May & 10 & 248.8 & 79. 08 & 9 & 1. 689 & 2. 135 & 18 & 310 & 2. 701 & 3. 041 \\
\hline 08 May & II & 241.9 & 86. 24 & 8 & I. 501 & 1. 740 & 12 & 267 & 2.326 & 2. 701 \\
\hline 09 Мау & 12 & 269.9 & 78. 91 & 7 & 1.313 & 1. 664 & 7 & 168 & 1.464 & 1. 856 \\
\hline 10 May & 13 & 253.0 & 93.76 & 10 & 1.876 & 2. 001 & 3 & 73 & 0.636 & 0.680 \\
\hline 11 May & 14 & 222.7 & 91.17 & 5 & 0.938 & 1. 029 & । & 25 & 0.218 & 0.235 \\
\hline 12 Myy & 15 & 260.3 & 74. 66 & 7 & 1.313 & 1. 759 & 2 & 55 & 0.479 & 0.645 \\
\hline 13 May & 16 & 279.6 & 70.01 & 3 & 0.563 & 0.804 & 3 & 48 & 0.418 & 0.601 \\
\hline 14 May & 17 & 269.8 & 73.96 & 0 & 0.000 & 0.000 & 3 & 40 & 0.348 & 0.470 \\
\hline 15 Nay & 18 & 263.3 & 66.79 & 2 & 0.375 & 0.562 & 6 & 59 & 0.514 & 0.767 \\
\hline 16 May & 19 & 279.6 & 65.75 & 2 & 0.375 & 0.571 & 4 & 29 & 0.253 & 0.383 \\
\hline 17 May & 20 & 251.3 & 74. 27 & 0 & 0.000 & 0.000 & I & 7 & 0.061 & 0.078 \\
\hline 18 May & 21 & 230.2 & 79.73 & 0 & 0.000 & 0.000 & I & 10 & 0.087 & 0.113 \\
\hline 19 Nay & 22 & 231.1 & 75. 32 & 0 & 0.000 & 0.000 & 2 & 20 & 0.174 & 0.235 \\
\hline 20 May & 23 & 202.3 & 83.80 & 1 & 0.188 & 0.224 & 0 & 0 & 0.000 & 0.000 \\
\hline 21 May & 24 & 181.5 & 98.74 & 0 & 0.000 & 0.000 & 1 & 7 & 0.061 & 0.061 \\
\hline 22 May & 25 & 195.3 & 91.89 & 0 & 0.000 & 0.000 & I & 5 & 0.044 & 0.044 \\
\hline 23 May & 26 & 190.2 & 93.60 & 0 & 0.000 & 0.000 & I & 5 & 0.044 & 0.044 \\
\hline $24 \mathrm{May}$ & 27 & 182. 9 & 97.20 & 1 & 0.188 & 0.193 & 1 & 7 & 0.061 & 0.061 \\
\hline 25 Nay & 28 & 181.8 & 100.0 & 1 & 0.188 & 0.188 & 0 & 0 & 0.000 & 0.000 \\
\hline 26 Nay & 29 & 183.3 & 100.0 & 0 & 0.000 & 0.000 & 0 & 0 & 0.000 & 0.000 \\
\hline 27 Nay & 30 & 196. 1 & 100.0 & 0 & 0.000 & 0.000 & 2 & 10 & 0.087 & 0.087 \\
\hline 28 May & 31 & 186.6 & 100.0 & । & 0.188 & 0.188 & 0 & 0 & 0.000 & 0.000 \\
\hline 30 May & 41 & 204.1 & 100.0 & 0 & 0.000 & 0.000 & 1 & 7 & 0.061 & 0.061 \\
\hline $03 \mathrm{~J}$ un & 45 & 199.9 & 100.0 & 0 & 0.000 & 0.000 & 1 & 3 & 0.026 & 0.026 \\
\hline $08 \mathrm{~J}$ un & 50 & 194.0 & 100.0 & । & 0.188 & 0.188 & 0 & 0 & 0.000 & 0.000 \\
\hline II Jun & 53 & 187.5 & 100.0 & 0 & 0.000 & 0.000 & I & 1 & 0.009 & 0.009 \\
\hline II Jun & 54 & 140.0 & 100.0 & 0 & 0.000 & 0.000 & I & 1 & 0.009 & 0.009 \\
\hline \multirow[t]{2}{*}{$12 \mathrm{~J}$ un } & 55 & 154.7 & 100.0 & 0 & 0.000 & 0.000 & I & 14 & 0.122 & 0.122 \\
\hline & & & & $\mathbf{i} \mathbf{i} \mathbf{i}$ & 31. 895 & 37. 497 & 173 & 2. 612 & 22.76 & 24. 865 \\
\hline
\end{tabular}

I PIT tag recapture dates ( 24 hour day midni ght to midni ght) have been shifted to match the brand date (noon to noon).

2 of the fish detected at the ti ne of rel ease. 


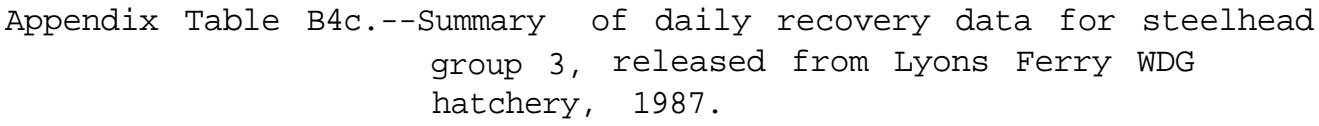

Rel ease date: 01 My 1987 Rel ease ti ne: 1300 hours

Nunber branded fi sh rel eased: 11.473

Number PI T tagged fi sh rel eased: 644(n) 524(c)

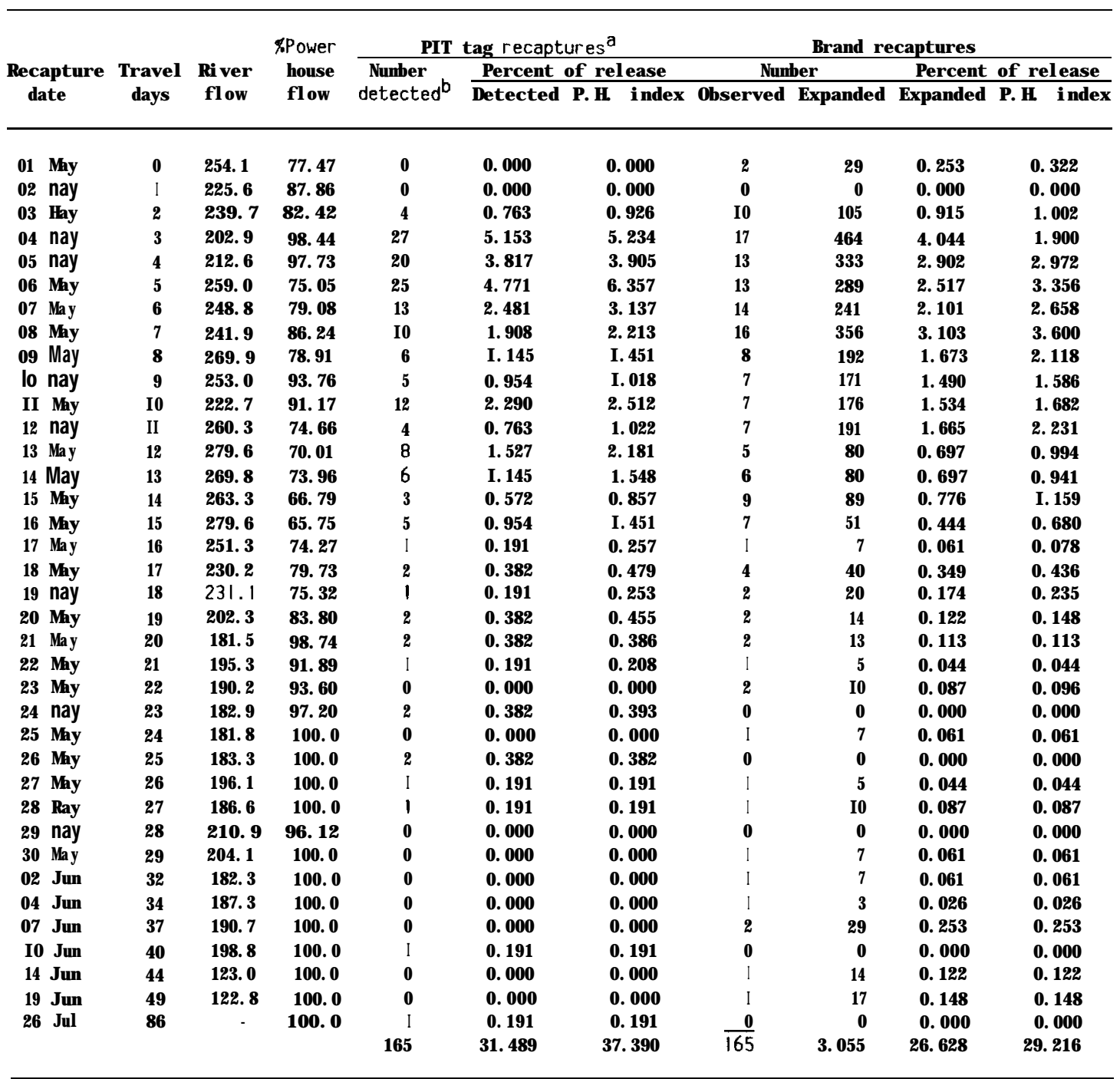

a PI T tag recapt ure dates (24-hour day midni ght to midni ght) have been shi fted to match the brand date (noon to noon).

$b$ of the fish detected at the ti ne of rel ease, 
$\begin{aligned} \text { Appendix Table B5a.-- } & \text { Summary of daily recovery data for steelhead } \\ & \text { group 1, released from Wells WDG hatchery, } \\ & 1987 .\end{aligned}$

Rel ease date: 23 Apr 1987 Rel ease ti ne: 1600 hours

Number branded fi sh rel eased: II. 279

Number PI T tagged fi sh rel eased: 631

\begin{tabular}{|c|c|c|c|c|c|c|c|c|c|c|}
\hline \multirow{3}{*}{$\begin{array}{l}\text { Recapt ure } \\
\text { date }\end{array}$} & \multirow{3}{*}{$\begin{array}{c}\text { Travel } \\
\text { days }\end{array}$} & \multirow{3}{*}{$\begin{array}{l}\text { Ri ver } \\
\text { fl ow }\end{array}$} & \multirow{3}{*}{$\begin{array}{l}\text { YPower } \\
\text { house } \\
\text { fl ow }\end{array}$} & \multicolumn{3}{|c|}{ PI T tag recaptures ${ }^{a}$} & \multicolumn{4}{|c|}{ Brand recaptures } \\
\hline & & & & \multirow{2}{*}{$\begin{array}{l}\text { Number } \\
\text { det ect ed }\end{array}$} & \multirow{2}{*}{$\frac{\text { Percent }}{\text { Detected }}$} & \multirow{2}{*}{$\begin{array}{l}\text { of rel ease } \\
\text { P. H i ndex }\end{array}$} & \multicolumn{2}{|c|}{ Nunber } & \multicolumn{2}{|c|}{ Percent of } \\
\hline & & & & & & & Observed & Expanded & Expanded & P. H i ndex \\
\hline $27 \mathrm{Apr}$ & 4 & 126.0 & 100.0 & 0 & 0.000 & 0.000 & 0 & 0 & 0.000 & 0.000 \\
\hline $\begin{array}{l}28 \mathrm{Apr} \\
29 \mathrm{Apr}\end{array}$ & $\begin{array}{l}5 \\
6\end{array}$ & $\begin{array}{l}153.8 \\
138.7\end{array}$ & $\begin{array}{l}100.0 \\
100.0\end{array}$ & $\begin{array}{r}3 \\
23\end{array}$ & $\begin{array}{l}0.475 \\
3.645\end{array}$ & $\begin{array}{l}0.475 \\
3.645\end{array}$ & $\begin{array}{l}3 \\
6\end{array}$ & $\begin{array}{l}43 \\
86\end{array}$ & $\begin{array}{l}0.381 \\
0.762\end{array}$ & $\begin{array}{l}0.381 \\
0.629\end{array}$ \\
\hline $\begin{array}{l}30 \mathrm{Apr} \\
01 \mathrm{May}\end{array}$ & $\begin{array}{l}7 \\
8\end{array}$ & $\begin{array}{l}206.1 \\
254.1\end{array}$ & $\begin{array}{l}95.24 \\
77.47\end{array}$ & $\begin{array}{l}20 \\
28\end{array}$ & $\begin{array}{l}3.170 \\
4.437\end{array}$ & $\begin{array}{l}3.328 \\
5.728\end{array}$ & $\begin{array}{l}14 \\
26\end{array}$ & $\begin{array}{l}200 \\
371\end{array}$ & $\begin{array}{l}\text { 1. } 773 \\
\text { 3. } 289\end{array}$ & $\begin{array}{l}1.330 \\
4.087\end{array}$ \\
\hline 02 Bay & 9 & 225.6 & 87.86 & 12 & 1. 902 & 2. 164 & 25 & 263 & 2. 332 & 2. 651 \\
\hline 03 Мау & 10 & 239.7 & 82.42 & 20 & 3. 170 & 3.846 & 26 & 274 & 2.430 & 2.722 \\
\hline 04 nay & II & 202.9 & 98.44 & 14 & 2. 219 & 2.254 & 6 & 164 & 1. 454 & 0.683 \\
\hline 05 Hay & 12 & 212.6 & 97.73 & II & 1.743 & 1. 784 & 5 & 128 & I. 135 & 1. 161 \\
\hline 06 Hay & 13 & 259.0 & 75.05 & 9 & 1.426 & 1.900 & 2 & 44 & 0.390 & 0.523 \\
\hline 07 May & 14 & 248.8 & 79.08 & 14 & 2. 219 & 2.806 & 5 & 86 & 0.762 & 0.966 \\
\hline 08 May & 15 & 241.9 & 86.24 & 7 & I. 109 & 1. 286 & II & 244 & 2. 163 & 2. 509 \\
\hline 09 nay & 16 & 269. 9 & 78.91 & 4 & 0.634 & 0.803 & 7 & 168 & 1. 489 & 1.888 \\
\hline in flay & 17 & 253.0 & 93.76 & 7 & I. 109 & I. 183 & 5 & 122 & 1.082 & I. 153 \\
\hline II nay & 18 & 222.7 & 91. 17 & 5 & 0.792 & 0.869 & 7 & 176 & 1. 560 & 1.711 \\
\hline 12 Myy & 19 & 260.3 & 74.66 & 4 & 0.634 & 0.849 & 8 & 218 & 1. 933 & 2. 589 \\
\hline 13 May & 20 & 279.6 & 70.01 & 3 & 0.475 & 0.679 & 6 & 96 & 0.851 & I. 215 \\
\hline 14 nay & 21 & 269.8 & 73. 96 & 5 & 0.792 & I. 071 & 2 & 27 & 0.239 & 0.328 \\
\hline 15 May & 22 & 263.3 & 66.79 & 0 & 0.000 & 0.000 & 1 & 10 & 0.089 & 0.133 \\
\hline 16 May & 23 & 279.6 & 65.75 & I & 0. 158 & 0.241 & 6 & 44 & 0.390 & 0.594 \\
\hline 17 Hay & 24 & 251.3 & 74. 27 & I & 0.158 & 0.213 & 5 & 33 & 0.293 & 0.390 \\
\hline 18 May & 25 & 230.2 & 79.73 & 1 & 0.158 & 0.199 & 3 & 30 & 0.266 & 0.337 \\
\hline 19 May & 26 & 231.1 & 75. 32 & 1 & 0.158 & 0.210 & 0 & 0 & 0.000 & 0.000 \\
\hline 20 Hay & 27 & 202. 3 & 83. 80 & 0 & 0.000 & 0.000 & 1 & 7 & 0.062 & 0.071 \\
\hline $21 \mathrm{May}$ & 28 & 181.5 & 98.74 & 0 & 0.000 & 0.000 & 0 & 0 & 0.000 & 0.000 \\
\hline $\begin{array}{l}22 \text { May } \\
23 \text { May }\end{array}$ & $\begin{array}{l}29 \\
30\end{array}$ & $\begin{array}{l}195.3 \\
190.2\end{array}$ & $\begin{array}{l}91.89 \\
93.60\end{array}$ & $\begin{array}{l}0 \\
0\end{array}$ & $\begin{array}{l}0.000 \\
0.000\end{array}$ & $\begin{array}{l}0.000 \\
0.000\end{array}$ & $\begin{array}{l}1 \\
0\end{array}$ & $\begin{array}{l}5 \\
0\end{array}$ & $\begin{array}{l}0.044 \\
0.000\end{array}$ & $\begin{array}{l}0.044 \\
0.000\end{array}$ \\
\hline 24 May & 31 & 182.9 & 97.20 & 0 & 0.000 & 0.000 & 0 & 0 & 0.000 & 0.000 \\
\hline 25 nay & 32 & 181.8 & 100.0 & 0 & 0.000 & 0.000 & 0 & 0 & 0.000 & 0.000 \\
\hline 26 May & 33 & 183. 3 & 100.0 & 0 & 0.000 & 0.000 & 0 & 0 & 0.000 & 0.000 \\
\hline 27 nay & 34 & 196. 1 & 100.0 & 0 & 0.000 & 0.000 & 0 & 0 & 0.000 & 0.000 \\
\hline 28 Ray & 35 & 186.6 & 100.0 & 1 & 0.158 & 0.158 & 1 & 10 & 0.089 & 0.089 \\
\hline 29 May & 36 & 210.9 & 96.12 & 0 & 0.000 & 0.000 & 0 & 0 & 0.000 & 0.000 \\
\hline $30 \mathrm{Myy}$ & 37 & 204. 1 & 100.0 & 0 & 0.000 & 0.000 & 0 & 0 & 0.000 & 0.000 \\
\hline 31 Hay & 38 & 178.7 & 100.0 & 0 & 0.000 & 0.000 & 0 & 0 & 0.000 & 0.000 \\
\hline \multirow[t]{2}{*}{$01 \mathrm{~J}$ un } & 39 & 173.5 & 100.0 & i & 0.158 & 0.158 & 0 & & 0.000 & 0.000 \\
\hline & & & & 195 & 30.903 & 35. 852 & 182 & $2 \overline{84}$ & 25. 259 & 28. 185 \\
\hline
\end{tabular}

a PI T tag recapture dates (24-hour day midni ght to midni ght) have been shl fted to match the brand date (noon to noon). 


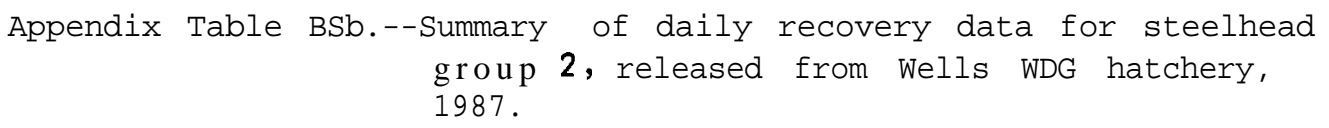

\begin{tabular}{|c|c|c|c|c|c|c|c|c|c|c|}
\hline \multirow{3}{*}{$\begin{array}{l}\text { Recapt ure } \\
\text { date }\end{array}$} & \multirow{3}{*}{$\begin{array}{c}\text { Travel } \\
\text { days }\end{array}$} & \multirow{3}{*}{$\begin{array}{l}\text { Ri ver } \\
\text { fl ow }\end{array}$} & \multirow{3}{*}{$\begin{array}{l}\text { XPower } \\
\text { house } \\
\text { fl ow }\end{array}$} & \multicolumn{3}{|c|}{ PIT tag recaptures ${ }^{a}$} & \multicolumn{4}{|c|}{ Brand recaptures } \\
\hline & & & & \multirow{2}{*}{$\begin{array}{l}\text { Number } \\
\text { det ect ed }\end{array}$} & \multirow{2}{*}{$\frac{\text { Percent }}{\text { Det ect ed }}$} & of rel ease & \multicolumn{2}{|c|}{ Nunber } & \multicolumn{2}{|c|}{ Percent of rel ease } \\
\hline & & & & & & P. H I ndex & Cbserved & Expanded & Expanded & P. H i ndex \\
\hline 30 Apr & 3 & 206. 1 & 95.24 & 2 & 0.316 & 0.332 & 0 & 0 & 0.000 & 0.000 \\
\hline 01 Nay & 4 & 254.1 & 77.47 & 21 & 3. 323 & 4. 289 & 12 & 171 & 1. 496 & I. 532 \\
\hline 02 Ray & 5 & 225.6 & 87.86 & 32 & 5.063 & 5.763 & 29 & 305 & 2.668 & 3. 184 \\
\hline 03 Ray & 6 & 239.7 & 82.42 & 27 & 4. 272 & 5. 183 & 32 & 337 & 2.948 & 3. 753 \\
\hline 04 May & 7 & 202.9 & 98.44 & 25 & 3. 956 & 4.018 & 16 & 437 & 3. 823 & 1.890 \\
\hline 05 Nay & 8 & 212.6 & 97.73 & 17 & 2.690 & 2.752 & 15 & 385 & 3. 368 & 3. 129 \\
\hline 06 nay & 9 & 259.0 & 75.05 & 10 & 1. 582 & 2. 108 & 8 & 178 & 1. 557 & 2. 175 \\
\hline 07 nay & 10 & 248.8 & 79.08 & 22 & 3. 481 & 4. 402 & 14 & $24 \mathrm{I}$ & 2. 108 & 2. 799 \\
\hline 08 Ray & II & 241.9 & 86.24 & 7 & I. 108 & 1. 284 & 6 & 133 & I. 164 & I. 413 \\
\hline 09 nay & 12 & 269.9 & 78. 91 & 8 & 1. 266 & 1.604 & 10 & 240 & 2. 100 & 2.789 \\
\hline 10 Ray & 13 & 253.0 & 93.76 & 5 & 0.791 & 0.844 & 4 & 98 & 0.857 & 0.963 \\
\hline I I May & 14 & 222.7 & 91. 17 & 6 & 0.949 & I. 041 & II & 276 & 2. 415 & 2. 780 \\
\hline 12 nay & 15 & 260.3 & 74.66 & 8 & 1. 266 & 1. 695 & 5 & 136 & I. 190 & 1.670 \\
\hline 13 My & 16 & 279.6 & 70.01 & 7 & 1.108 & 1. 582 & 6 & 96 & 0.840 & 1. 257 \\
\hline 14 nay & 17 & 269.8 & 73. 96 & 5 & 0.791 & 1.070 & 2 & 27 & 0.236 & 0.339 \\
\hline 15 May & 18 & 263.3 & 66.79 & 5 & 0.791 & I. 184 & 6 & 59 & 0.516 & 0.807 \\
\hline 16 nay & 19 & 279.6 & 65.75 & 0 & 0.000 & 0.000 & 5 & 36 & 0.315 & 0.505 \\
\hline 17 Ray & 20 & 251.3 & 74. 27 & 7 & I. 108 & I. 491 & 6 & 0 & 0.000 & 0.495 \\
\hline I8 May & 21 & 230.2 & 79.73 & 0 & 0.000 & 0.000 & 8 & 80 & 0.700 & 0.918 \\
\hline 19 nay & 22 & 231.1 & 75. 32 & 0 & 0.000 & 0.000 & 2 & 20 & 0.175 & 0.248 \\
\hline 20 Ray & 23 & 202.3 & 83. 80 & 2 & 0.316 & 0.378 & 3 & 21 & 0.184 & 0.229 \\
\hline 21 May & 24 & 181.5 & 98.74 & I & 0.158 & 0.160 & 0 & 0 & 0.000 & 0.000 \\
\hline 22 nay & 25 & 195. 3 & 91.89 & 0 & 0.000 & 0.000 & 0 & 0 & 0.000 & 0.000 \\
\hline 23 Myy & 26 & 190.2 & 93.60 & 0 & 0.000 & 0.000 & I & 5 & 0.044 & 0.046 \\
\hline 24 May & 27 & 182. 9 & 97.20 & 1 & 0.158 & 0.163 & 1 & 7 & 0.061 & 0.064 \\
\hline 25 May & 28 & 181.8 & 100.0 & 0 & 0.000 & 0.000 & 0 & 0 & 0.000 & 0.000 \\
\hline 26 Ray & 29 & 183.3 & 100.0 & 0 & 0.000 & 0.000 & 0 & 0 & 0.000 & 0.000 \\
\hline 27 Ray & 30 & 196.1 & 100.0 & 0 & 0.000 & 0.000 & 0 & 0 & 0.000 & 0.000 \\
\hline 28 Ray & 31 & 186.6 & 100.0 & i & 0.158 & 0.158 & 0 & 0 & 0.000 & 0.000 \\
\hline 29 May & 32 & 210.9 & 96.12 & 0 & 0.000 & 0.000 & 1 & 8 & 0.070 & 0.073 \\
\hline \multirow[t]{2}{*}{30 Ray } & 33 & 204. 1 & 100.0 & 1 & 0.158 & 0.158 & 1 & 7 & 0.061 & 0.064 \\
\hline & & & & $\overline{220}$ & 34.810 & 41.662 & $\overline{204}$ & 3,303 & 28. 898 & 33. 125 \\
\hline
\end{tabular}

${ }^{\text {a }}$ PI T tag recapture dates (24-hour day ni dni ght to midni ght) have been shifted to match the brand date (noon to noon). 
$\begin{aligned} \text { Appendix Table B5c.- } & \text { Summary of daily recovery data for steelhead } \\ & \text { group 3, released from Wells WDG hatchery, } \\ & 1987 .\end{aligned}$

Rel ease date: 01 May 1987 Rel ease ti ne: 1600 hours

Number branded fi sh rel eased: I 1,375

Nunber PIT tagged fi sh rel eased: $\mathbf{6 1 6}$

\begin{tabular}{|c|c|c|c|c|c|c|c|c|c|c|}
\hline \multirow{3}{*}{$\begin{array}{l}\text { Recapt ure } \\
\text { date }\end{array}$} & \multirow{3}{*}{$\begin{array}{l}\text { Travel } \\
\text { days }\end{array}$} & \multirow{3}{*}{$\begin{array}{l}\text { River } \\
\text { fl ow }\end{array}$} & \multirow{3}{*}{$\begin{array}{l}\text { MPower } \\
\text { house } \\
\text { fl ow }\end{array}$} & \multicolumn{3}{|c|}{ PI T tag recaptures ${ }^{a}$} & \multicolumn{4}{|c|}{ Brand recaptures } \\
\hline & & & & \multirow{2}{*}{$\begin{array}{l}\text { Nunber } \\
\text { det ect ed }\end{array}$} & \multirow{2}{*}{\multicolumn{2}{|c|}{$\frac{\text { Percent of rel ease }}{\text { Detected P. H i ndex }}$}} & \multicolumn{2}{|c|}{ Nunber } & \multirow{2}{*}{$\begin{array}{r}\text { Percent } \\
\text { Expanded }\end{array}$} & \multirow{2}{*}{$\begin{array}{l}\text { of rel ease } \\
\text { P. } \mathrm{H} \text { i ndex }\end{array}$} \\
\hline & & & & & & & Observed & Expanded & & \\
\hline 02 May & । & 225.6 & 87.86 & 0 & 0.000 & 0.000 & । & II & 0.095 & 0.114 \\
\hline 03 Мау & 2 & 239.7 & 82.42 & 0 & 0.000 & 0.000 & 0 & 0 & 0.000 & 0.000 \\
\hline 04 May & 3 & 202.9 & 98.44 & 20 & 3. 247 & 3. 298 & 0 & 0 & 0.000 & 0.000 \\
\hline 05 May & 4 & 212.6 & 97.73 & 39 & 6. 331 & 6.478 & 6 & 154 & 1. 334 & 1.152 \\
\hline 06 Myy & 5 & 259.0 & 75.05 & 25 & 4. 058 & 5.408 & 13 & 289 & 2. 503 & 3. 130 \\
\hline 07 May & 6 & 248.8 & 79.08 & 28 & 4. 545 & 5. 748 & 24 & 414 & 3. 586 & 4. 607 \\
\hline 08 Мау & 7 & 241.9 & 86. 24 & 18 & 2. 922 & 3. 388 & 23 & 511 & 4. 426 & 5. 213 \\
\hline 09 Мөу & 8 & 269.9 & 78. 91 & 21 & 3. 409 & 4. 320 & II & 264 & 2. 286 & 2. 945 \\
\hline 10 Hay & 9 & 253.0 & 93.76 & 19 & 3. 084 & 3. 290 & 15 & 367 & 3. 177 & 3. 437 \\
\hline II May & 10 & 222.7 & 91.17 & 10 & 1.623 & I. 781 & 13 & 327 & 2. 832 & 3. 156 \\
\hline 12 Ray & II & 260.3 & 74. 66 & 13 & 2. 110 & 2. 827 & 6 & 164 & 1. 420 & 1.934 \\
\hline 13 My & 12 & 279.6 & 70.01 & 7 & I. 136 & 1. 623 & 8 & 128 & I. 109 & 1. 609 \\
\hline $14 \mathrm{fl}$ ay & 13 & 269.8 & 73. 96 & 10 & 1. 623 & 2. 195 & 3 & 40 & 0.346 & 0.475 \\
\hline 15 My & 14 & 263.3 & 66.79 & 4 & 0.649 & 0.972 & 9 & 89 & 0.771 & 1.169 \\
\hline 16 May & 15 & 279.6 & 65.75 & 2 & 0.325 & 0.494 & 8 & 58 & 0.502 & 0.774 \\
\hline 17 Nay & 16 & 251.3 & 74. 27 & 4 & 0.649 & 0.874 & 8 & 53 & 0.459 & 0.624 \\
\hline $18 \mathrm{May}$ & 17 & 230.2 & 79.73 & 3 & 0.487 & $0.61 \mathrm{I}$ & 5 & 50 & 0.433 & 0.554 \\
\hline 19 May & 18 & 231. 1 & 75. 32 & 4 & 0.649 & 0.862 & 2 & 20 & 0.173 & 0.237 \\
\hline 20 May & 19 & 202.3 & 83. 80 & 2 & 0.325 & 0.387 & 9 & 62 & 0.537 & 0.650 \\
\hline $21 \mathrm{My}$ & 20 & 181.5 & 98.74 & 0 & 0.000 & 0.000 & 2 & 13 & 0.113 & 0.114 \\
\hline 22 My & 21 & 195. 3 & 91.89 & 0 & 0.000 & 0.000 & 0 & 0 & 0.000 & 0.000 \\
\hline 23 May & 22 & 190.2 & 93.60 & 0 & 0.000 & 0.000 & 2 & 10 & 0.087 & 0.097 \\
\hline 24 May & 23 & 182.9 & 97.20 & 0 & 0.000 & 0.000 & । & 7 & 0.061 & 0.061 \\
\hline 25 Nay & 24 & 181.8 & 100.0 & 0 & 0.000 & 0.000 & 0 & 0 & 0.000 & 0.000 \\
\hline 26 May & 25 & 183.3 & 100.0 & 0 & 0.000 & 0.000 & । & 7 & 0.061 & 0.061 \\
\hline 27 May & 26 & 196. I & 100.0 & 0 & 0.000 & 0.000 & 1 & 5 & 0.043 & 0.044 \\
\hline $28 \mathrm{Mgy}$ & 27 & 186.6 & 100.0 & 0 & 0.000 & 0.000 & 0 & 0 & 0.000 & 0.000 \\
\hline $29 \mathrm{May}$ & 28 & 210.9 & 96. 12 & 0 & 0.000 & 0.000 & I & 8 & 0.069 & 0.070 \\
\hline 30 Hy & 29 & 204. I & 100.0 & 0 & 0.000 & 0.000 & i & 7 & 0.061 & 0.061 \\
\hline 31 Myy & 30 & 178.7 & 100.0 & 0 & 0.000 & 0.000 & 0 & 0 & 0.000 & 0.000 \\
\hline (I) J un & 31 & 173.5 & 100.0 & 0 & 0.000 & 0.000 & 0 & 0 & 0.000 & 0.000 \\
\hline $02 \mathrm{~J}$ un & 32 & 182.3 & 100.0 & 0 & 0.000 & 0.000 & 0 & 0 & 0.000 & 0.000 \\
\hline $03 \mathrm{~J}$ un & 33 & 199.9 & 100.0 & 0 & 0.000 & 0.000 & 0 & 0 & 0.000 & 0.000 \\
\hline & 34 & 187.3 & 100.0 & 0 & 0.000 & 0.000 & 0 & 0 & 0.000 & 0.000 \\
\hline \multirow{2}{*}{$05 \mathrm{Jun}$} & 35 & 169.2 & 100.0 & 0 & 0.000 & 0.000 & I & 14 & 0.121 & 0.123 \\
\hline & & & & $\overline{229}$ & 37.175 & 44. 556 & $\overline{174}$ & 3,072 & 26.607 & 32.413 \\
\hline
\end{tabular}

a PIT tag recapture dates (24-hour day midni ght to midni ght) have been shifted to match the brand date (noon to noon). 


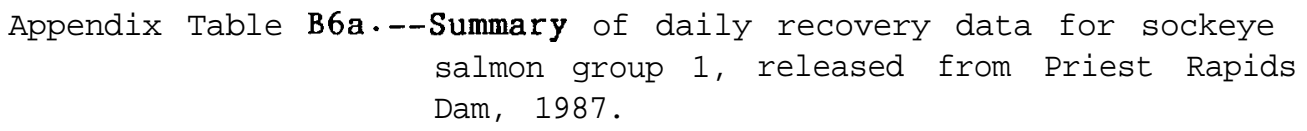

\begin{tabular}{|c|c|c|c|c|c|c|c|c|c|}
\hline \multirow{3}{*}{$\begin{array}{c}\text { Recapt ure } \\
\text { date }\end{array}$} & \multirow{3}{*}{$\begin{array}{l}\text { Ri ver } \\
\text { fl ow }\end{array}$} & \multirow{3}{*}{$\begin{array}{l}\text { xpower } \\
\text { house } \\
\text { fl ow }\end{array}$} & \multicolumn{3}{|c|}{ PI T tag recaptures ${ }^{a}$} & \multicolumn{4}{|c|}{ Brand recaptures } \\
\hline & & & \multirow{2}{*}{$\begin{array}{l}\text { Number } \\
\text { det ected }\end{array}$} & \multicolumn{2}{|c|}{ Percent of rel ease } & \multicolumn{2}{|c|}{ Nunber } & Percent & \multirow{2}{*}{$\begin{array}{l}\text { of rel ease } \\
\text { P. } \mathrm{H} \text { i ndex }\end{array}$} \\
\hline & & & & Detected & P. H i ndex & Observed & Expanded & Expanded & \\
\hline 10 Hay & 253.0 & 93.16 & 0 & 0.000 & 0.000 & 0 & 0 & 0.00000 & 0.00000 \\
\hline II Ray & 222.7 & 91.17 & 33 & 5.500 & 6.500 & 0 & 0 & 0.00000 & 0.00000 \\
\hline 12 円у & 260.3 & 14.66 & 26 & 4. 333 & 5.667 & 6 & 164 & 3.02360 & 4. 05605 \\
\hline 13 May & 279.6 & 70.01 & 6 & 1.000 & 1. 333 & 6 & 96 & 1. 76991 & 2. 52581 \\
\hline 14 Hy & 269.8 & 73.96 & 8 & 1. 333 & 1. 667 & 16 & 213 & 3. 92699 & 5. 30973 \\
\hline 15 Hy & 263.3 & 66.79 & 20 & 3. 333 & 4. 833 & 7 & 69 & 1. 27212 & 1. 89897 \\
\hline 16 May & 279.6 & 65.75 & 38 & 6.333 & 9.500 & 25 & 182 & 3. 35546 & 5. 10693 \\
\hline 17 Hy & 251.3 & 74. 27 & 30 & 5.000 & 6.667 & 33 & 220 & 4. 05605 & 5.45723 \\
\hline 18 Hay & 230.2 & 79.73 & 9 & 1. 500 & 1. 833 & 18 & 160 & 2. 94985 & 3. 70575 \\
\hline 19 円y & 231.1 & 75. 32 & 15 & 2.500 & 3. 167 & 6 & 40 & 1. 47493 & 1. 95428 \\
\hline 20 Hyy & 202.3 & 83.80 & 8 & 1.333 & 1. 500 & & & 0.75590 & 0.90339 \\
\hline 21 Hy & 181.5 & 98.74 & 6 & 1.000 & 1.000 & 3 & 20 & 0.36673 & 0.36873 \\
\hline 22 Hy & 195.3 & 91.89 & 0 & 0.000 & 0.000 & 6 & 30 & 0.55310 & 0.60841 \\
\hline 23 May & 190.2 & 93.60 & 4 & 0.667 & 0.667 & 6 & 30 & 0.55310 & 0.58997 \\
\hline 24 May & 182.9 & 97.20 & 1 & 0.167 & 0.167 & 3 & 20 & 0.36873 & 0.38717 \\
\hline 25 May & 181.8 & 100.0 & 0 & 0.000 & 0.000 & 1 & 7 & 0.12906 & 0.12906 \\
\hline 26 Hay & 183.3 & 100.0 & 1 & 0.167 & 0.167 & 1 & 7 & 0.12906 & 0.12906 \\
\hline 27 Hay & 196.1 & 100.0 & 0 & 0.000 & 0.000 & 1 & 5 & 0.09218 & 0.09218 \\
\hline 28 Hay & 186.6 & 100.0 & 0 & 0.000 & 0.000 & 4 & 40 & 0.73746 & 0.73746 \\
\hline 29 Hay & 210.9 & 96.12 & 0 & 0.000 & 0.000 & 2 & 16 & 0.29499 & 0.31342 \\
\hline 30 May & 204.1 & 100.0 & 0 & 0.000 & 0.000 & 29 & 193 & 3. 55826 & 3. 55826 \\
\hline 31 Hay & 178.7 & 100.0 & 0 & 0.000 & 0.000 & & 7 & 012906 & 0. 12906 \\
\hline & 4834. 0 & 1926.0 & 205 & 34. 167 & $\overline{44.667}$ & $\overline{180}$ & 1. 600 & 29.49850 & 37.96090 \\
\hline
\end{tabular}

a PI T tag recapture dates (24-hour day midni ght to midni ght) have been shifted to match the brand date (noon to noon). 


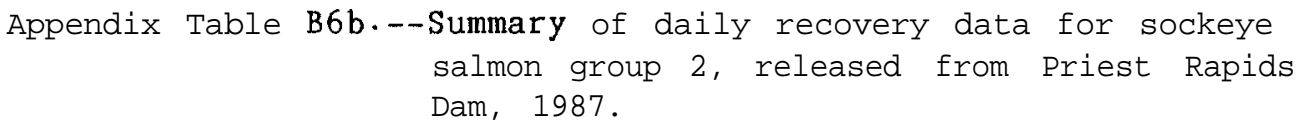

Rel ease date: 18 May 1987 through 23 Myy 1987 Rel ease ti ne: 2300 hours

Nunber branded fish rel eased: 5,349

Number PI T tagged fi sh rel eased: 600

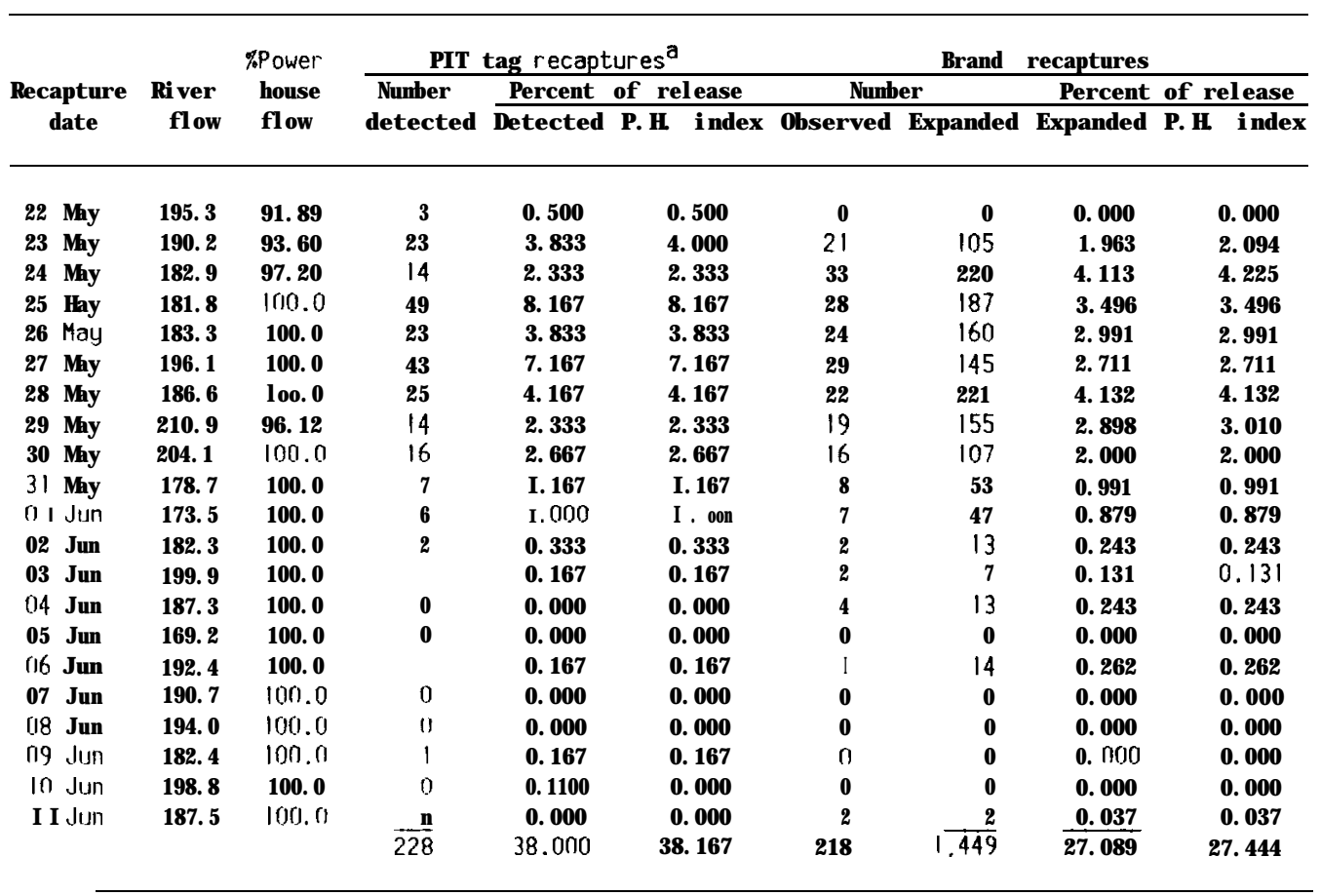

a PIT tag recapt ure dates (24-hour day mI dnight to midni ght) have been shifted to match the brand date (noon to noon). 


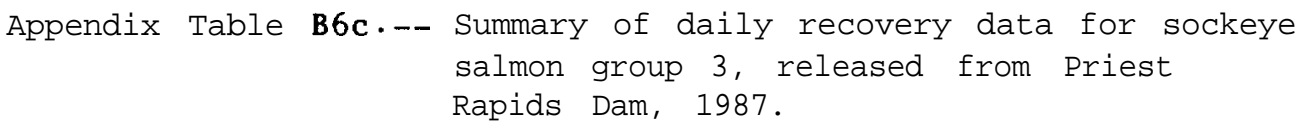

Rel ease date: 24 Hay 1987 through 25 May 1987 Release ti me: 2300 hours

Nunber branded fi sh rel eased: 5.050

Number PI T tagged fi sh rel eased: 600

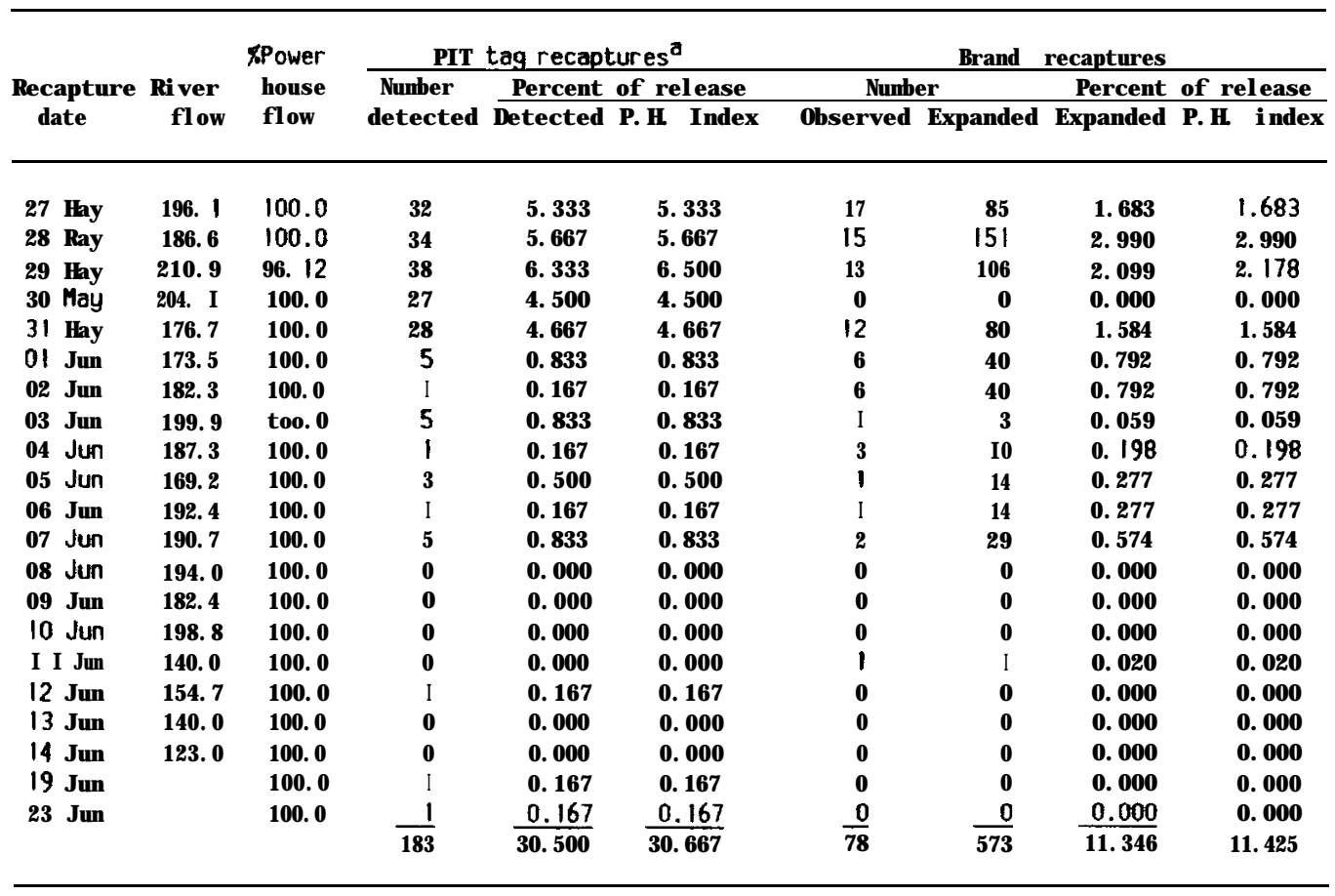

a PIT tag recapture dates (24-hour day midni ght to midni ght) have been shifted to match the brand date (noon to noon). 
APPENDIX C

Figures of Recaptures by Date 


\section{PERCENT DETECTION OF CHINOOK \\ FROM LYONS FERRY RELEASE}
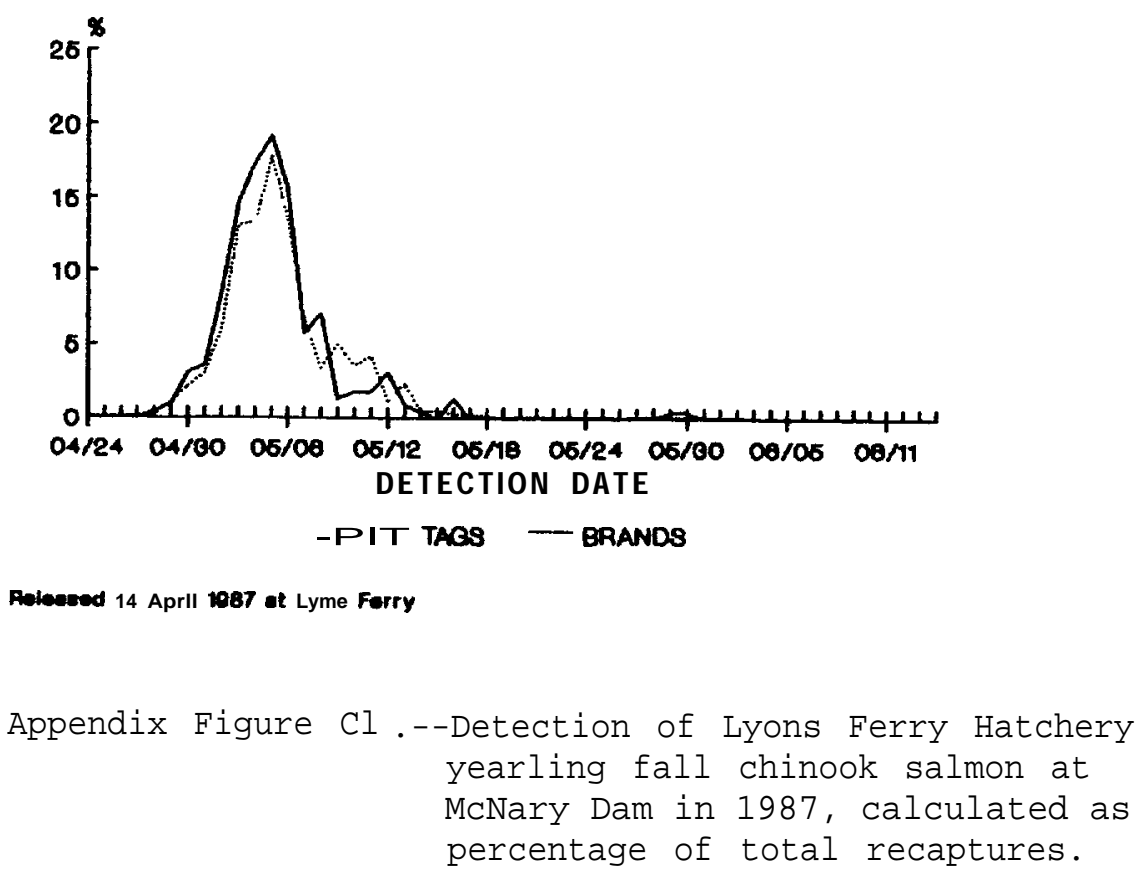


\section{PERCENT DETECTION OF CHINOOK FROM WINTHROP RELEASE GROUP 1}

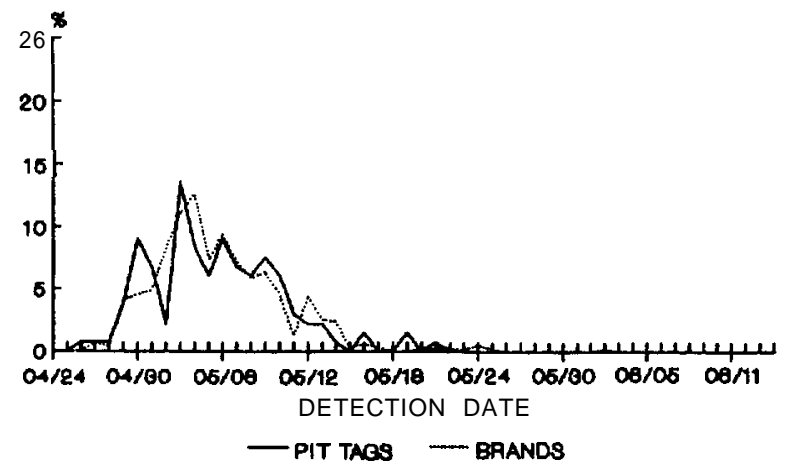

Fulceened 20 April 1087 at Prleet Raplda

\section{PERCENT DETECTION OF CHINOOK} FROM WINTHROP RELEASE GROUP 2

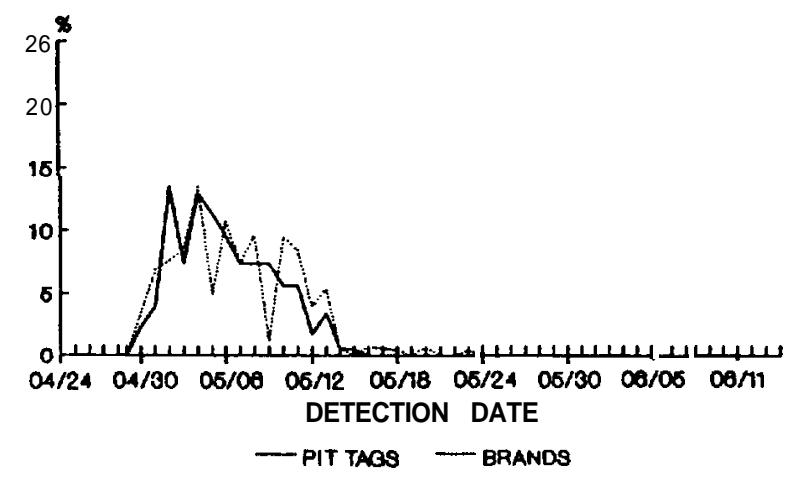

Feteased 24 Norll ,987 at Pricel Radich

PERCENT DETECTION OF CHINOOK FROM WINTHROP RELEASE GROUP 3

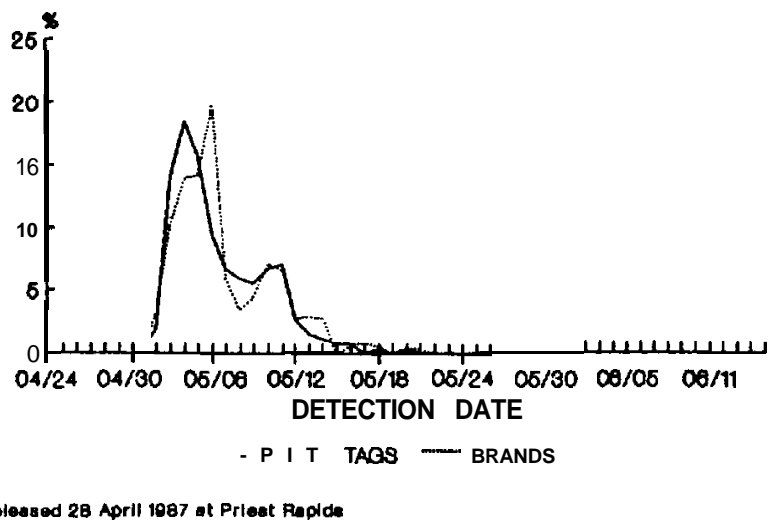

Appendix Figure C2.--Detection of Winthrop Hatchery spring chinook salmon at McNary Dam in 1987, calculated as percentage of total recaptures. 
PERCENT DETECTION OF CHINOOK FROM PREST RAPIDS RELEASE GROUP 1

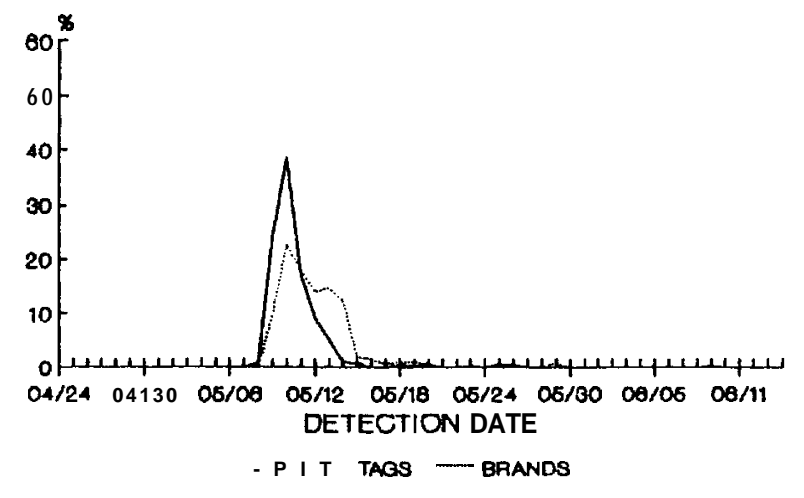

Feleased 6 Mey 1987 a Prieat Replde

PERCENT DETECTION OF CHNOOK

FROM PREST RAPIDS RELEASE GROUP 2

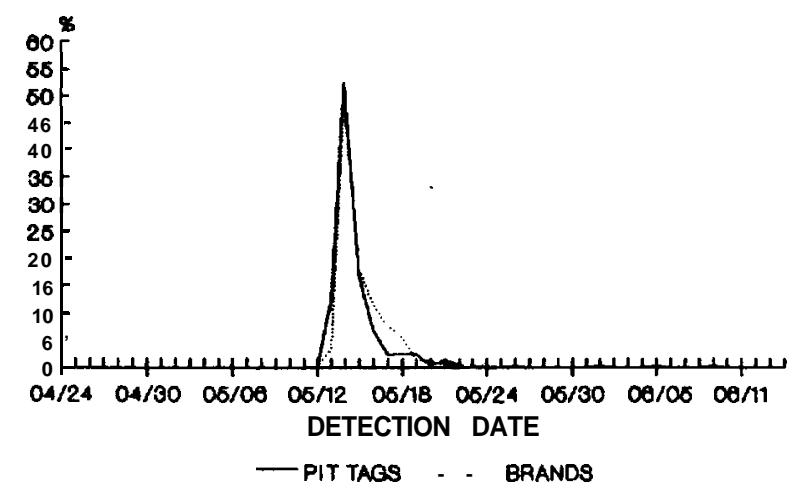

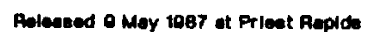

PERCENT DETECTION W CHMOOK FROM PRIEST RAPIDS RELEASE GROUP 3

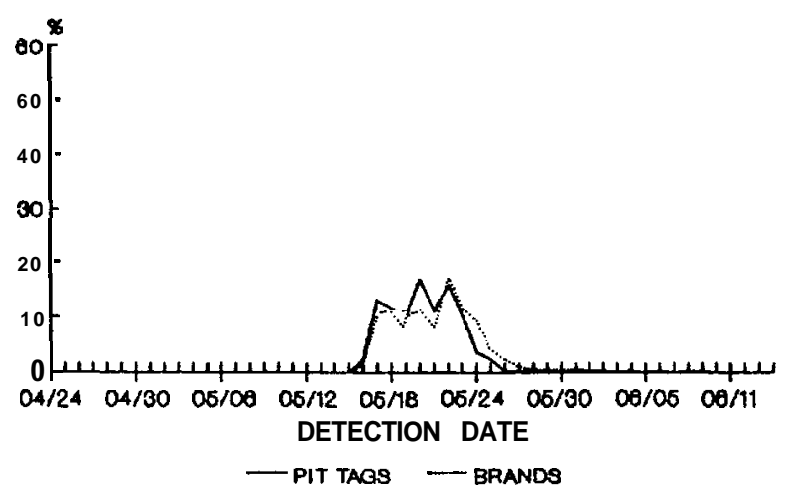

Released 18-10 May 1087 at Prisel Raplde

\footnotetext{
Appendix Figure C3.--Detection of Priest Rapids Dam migrant yearling chinook salmon at McNary Dam in 1987, calculated as percentage of total recaptures.
} 
PERCENT DETECTION OF STEELHEAD

FROM LYONS FERRY RELEASE GROUP 1

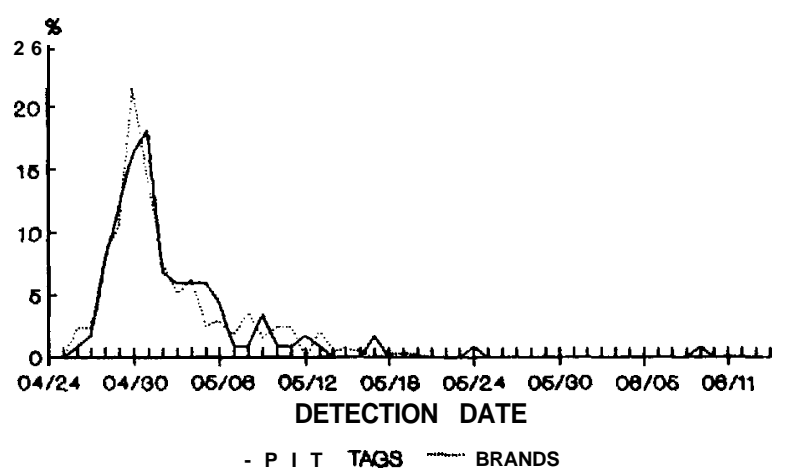

Aoleased 20 April 1987 at loe Harbor Dam

\section{PERCENT DETECTION OF STEELHEAD} FROM LYONS FERRY RELEASE GROUP 2

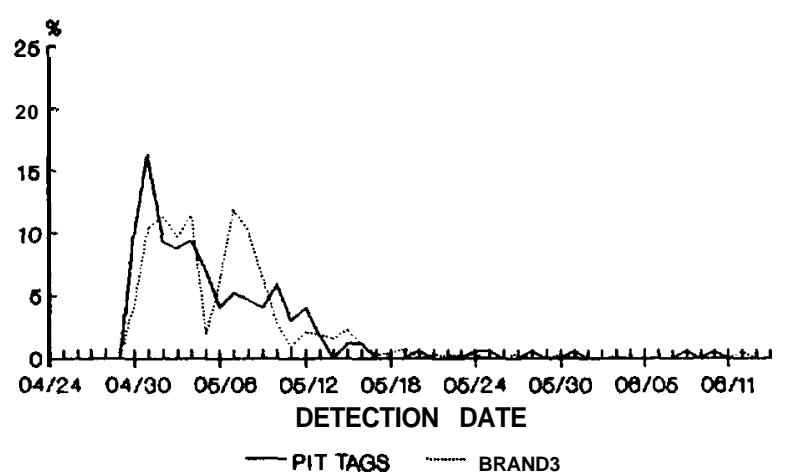

Releened 27 April 1087 at loe Marbor Dam

\section{PERCENT DETECTION OF STEELHEAD FROM LYONS FERRY RELEASE GROUP 3}

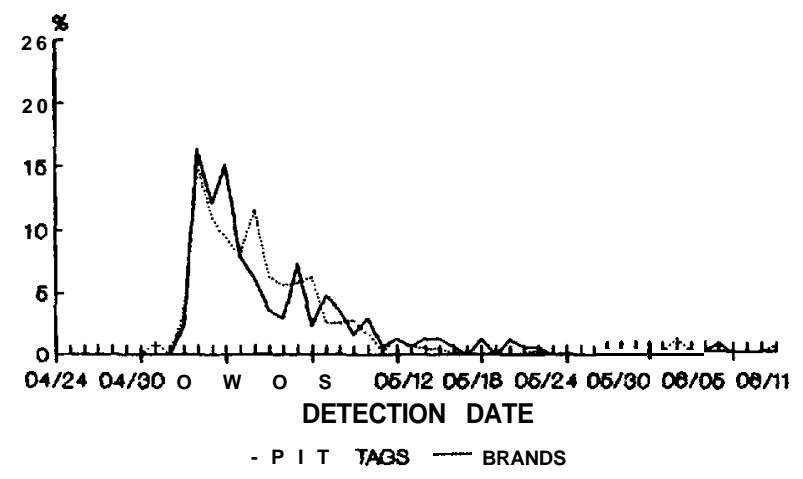

Aarcesed 1 May 1087 at loe Herbor Dem 


\section{PERCENT DETECTION OF STEELHEAD \\ FROM WELLS RELEASE GROUP 1}

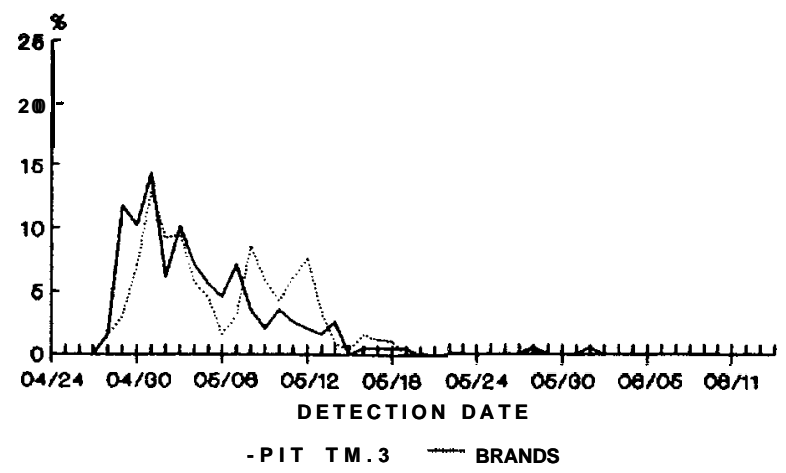

Feleuned 28 Aprll 1087 at Prieal Reolde.

\section{PERCENT DETECTION OF STEELHEAD} FROM WELLS RELEASE GROUP 2

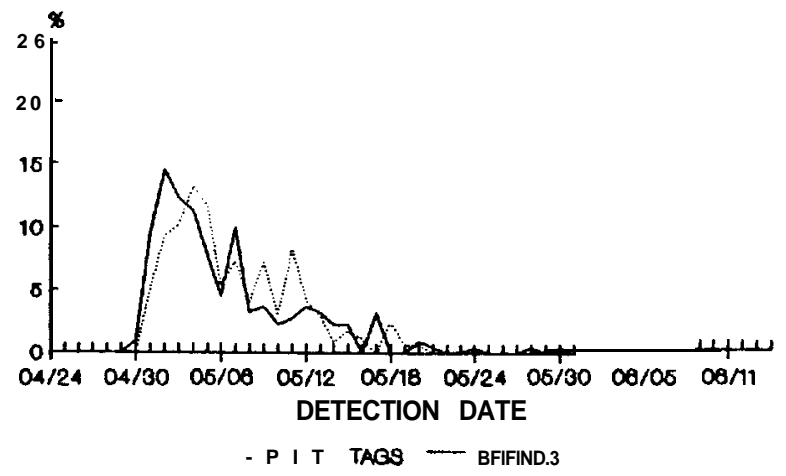

Poiceased 27 Aprll 1987 at Priset Rapldo

\section{PERCENT DETECTION OF STEELHEAD \\ FROM WELLS RELEASE GROUP 3}

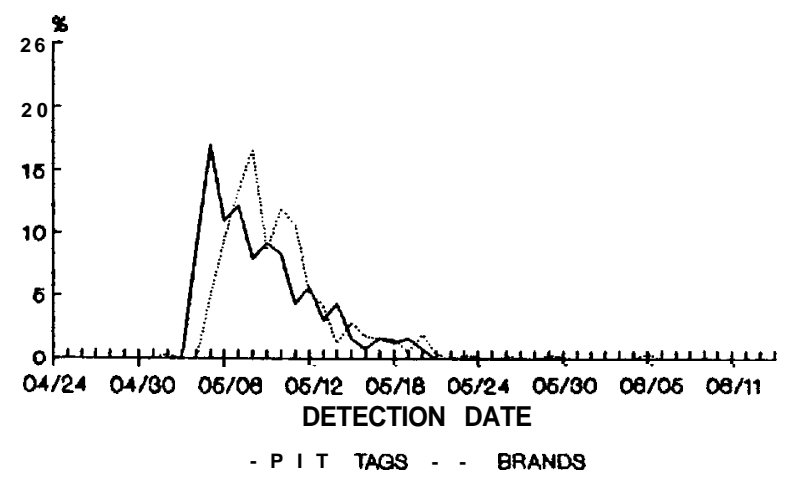

Paleased 1 May 1087 at Pricat Raolde. 
PERCENT DETECTION OF SOCKEYE

FROM PRIEST RAPIDS RELEASE GROUP 1

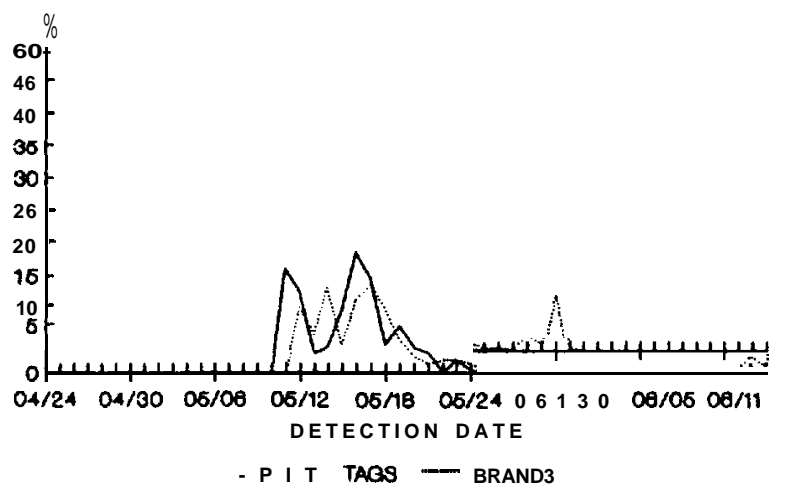

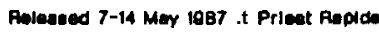

PERCENT DETECTION OF SOCKEYE

FROM PREST RAPIDS RELEASE GROUP 2

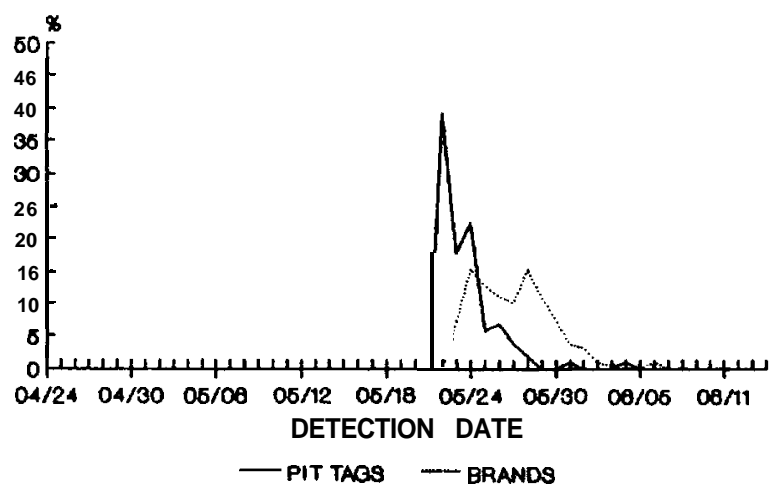

Paleaeed 18-28 Mey 10a7 at Prical Paplde

PERCENT DETECTION OF SOCKEYE

FROM PRIEST RAPIDS RELEASE GROUP 3

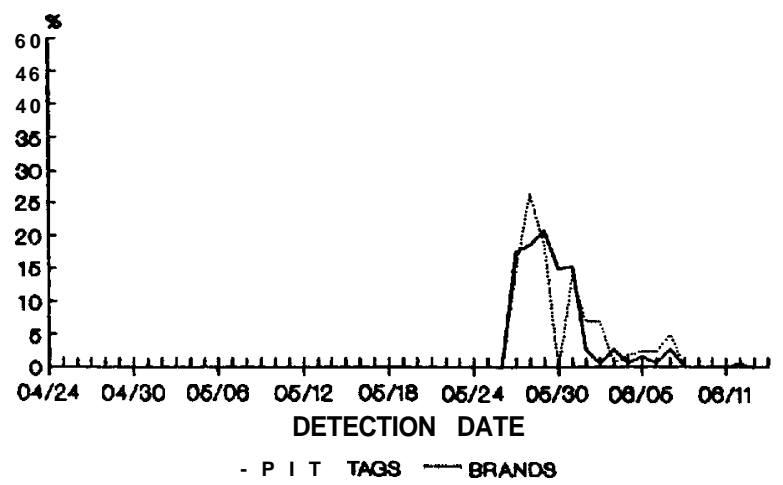

Proleaced 24-26 Moy 1087 at Prient Raplda

Appendix Figure C6.--Detection of Priest Rapids migrant sockeye salmon at McNary Dam in 1987, calculated as percentage of total recaptures. 
APPENDIX D

Figures of Diel Passage 
DIEL PASSAGE OF LYONS FERRY CHINOOK

AT MCNARY DAM IN 1987

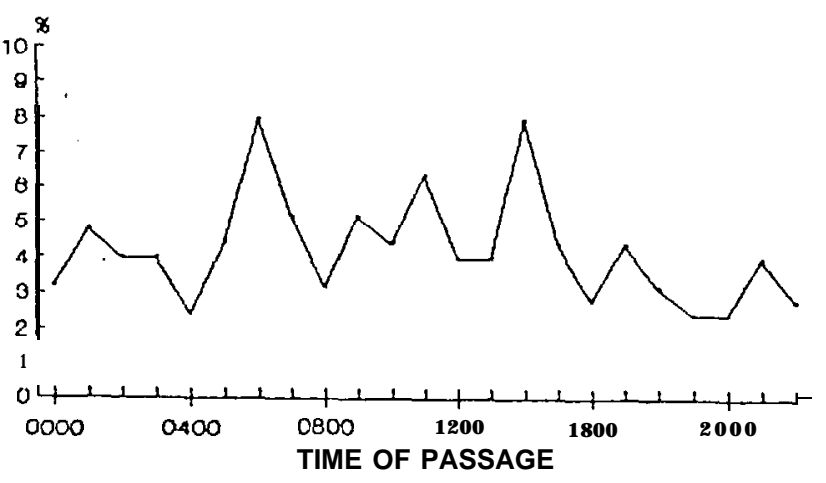

\section{DIEL PASSAGE OF WINTHROP CHINOOK}

AT MCNARY DAM IN 1987

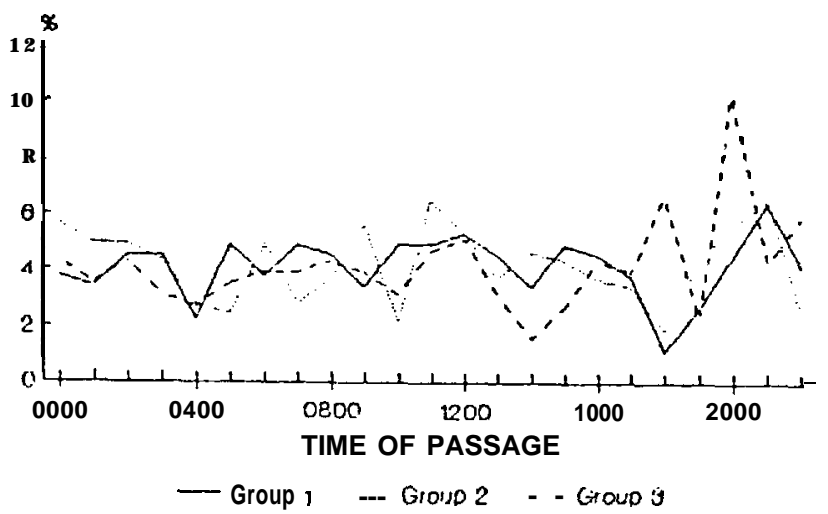

DIEL PASSAGE OF PRIEST RAPIDS CHINOOK AT MCNARY DAM IN 1987

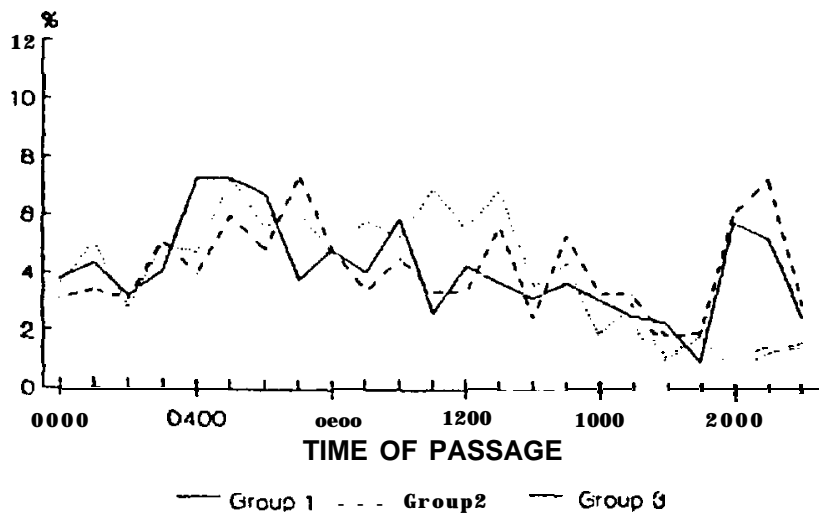

Appendix Figure D1.--Diel passage of PIT-tagged yearling chinook salmon detected while exiting the separator at McNary Dam in 1987. 
DIEL PASSAGE OF LYONS FERRY STEELHEAD

AT MCNARY DAM IN 1987

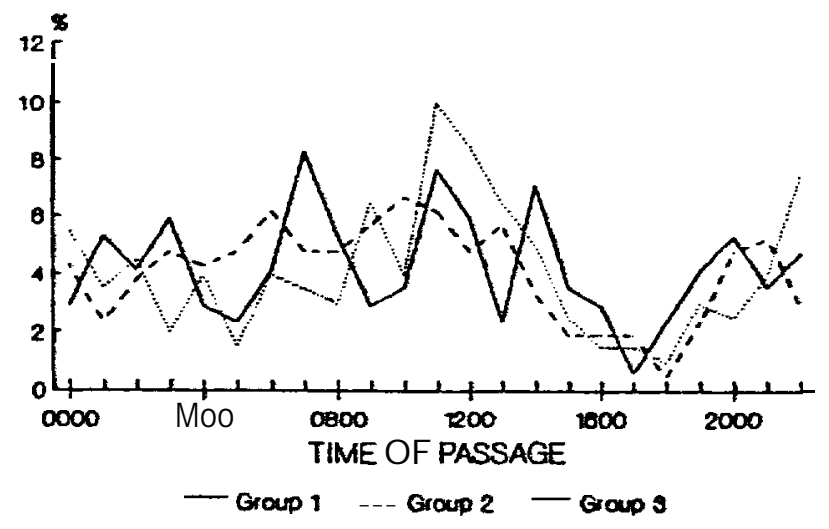

\section{DEL PASSAGE OF WELLS STEELHEAD}

AT MCNARY DAM IN 1987

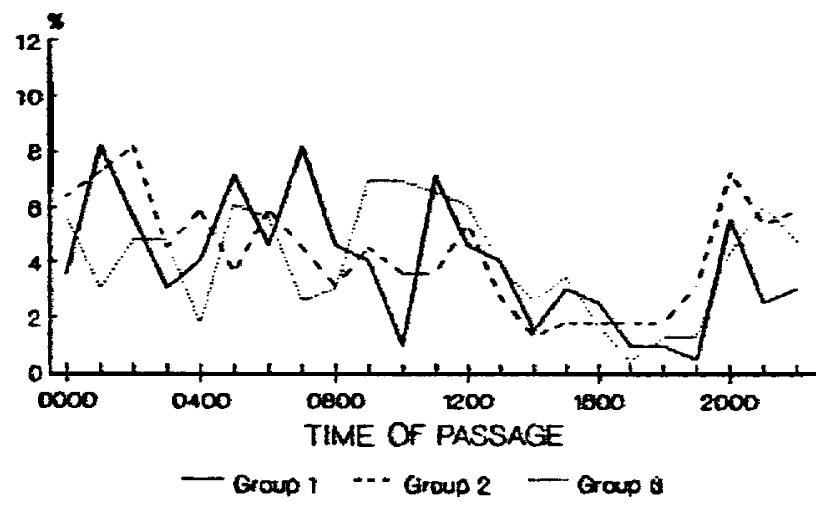

Appendix Figure D2.--Diel passage of PIT-tagged steelhead detected while exiting the separator at McNary Dam in 1987. 


\section{DIEL PASSAGE OF SOCKEYE} AT MCNARY DAM IN 1987

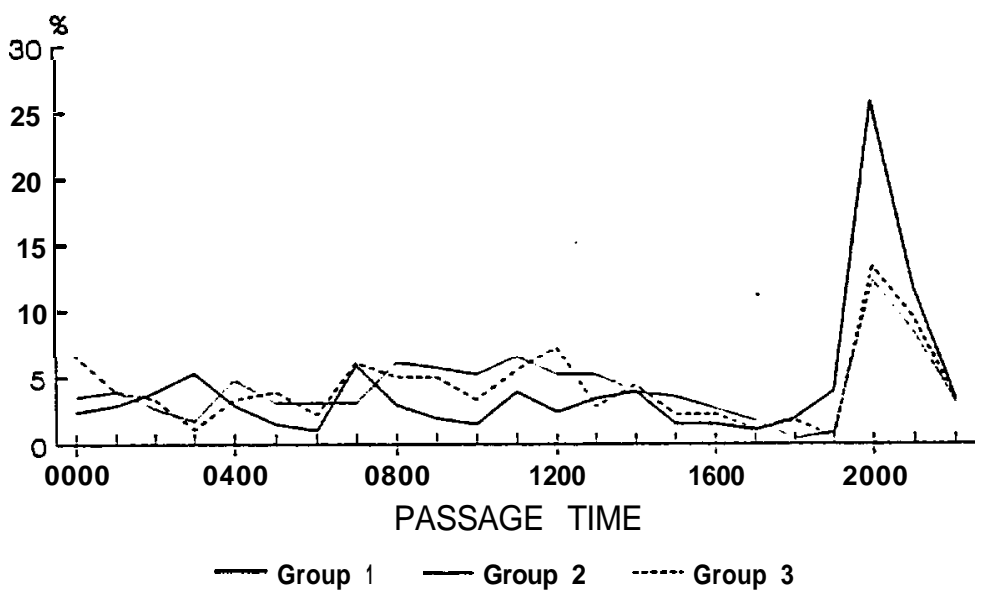

Appendix Figure D3.--Diel passage of PIT-tagged sockeye salmon detected. while exiting the separator at McNary Dam in 1987. 


\section{APPENDIX E}

Budget Information 


\section{Budget Information}

FY87

Salaries

Travel

Transport

Rents

Printing

Contract Service

Supplies

Equipment

Support

TOTAL
$\$ 14,283.74$

$2,379.29$

$1,789.74$

956.37

0

$1,729.00$

687.84

0

5.096 .42

$\$ 26,922.40$ 